\title{
ARMADILHAS PARA OS SENTIDOS: UMA EXPERIÊNCIA NO ESPAÇO-TEMPO DA ARTE
}

Ana Maria Tavares

Tese de Doutorado em Artes

Orientadora: Profa. Dra. Regina Silveira Departamento de Artes Plásticas Escola de COMunicações e Artes

Universidade de São Paulo

ANO 2000 


\section{BANCA EXAMINADORA}

São Paulo,

2000 
Esta tese compreende a criação de um conjunto de obras que propiciam uma experiência de deslocamento espaçotemporal no contexto da arte, a fim de aludir criticamente à experiência de passagem observada no contexto do espaço urbano contemporâneo. Essas obras, realizadas em diversos meios e materiais, foram apresentadas no período de 1995 a 2000 e visam constituir-se como elemento perturbador para desestabilizar as noções que tradicionalmente definiriam a escultura, a relação entre espectador e obra, e a própria arquitetura que lhe serve de suporte.

Na reflexão sobre essas questões vários temas emergem. $\mathrm{O}$ primeiro é a relação entre a arte e o design, que na obra é tensa e conduz a uma experiência que na tese se denomina “o conflito do sujeito". O segundo é o da amplificação dos sentidos através de uma experiência sinestésica que produz modificações na paisagem do mundo (da arte) e na percepção que o sujeito tem de si mesmo quando submetido ao espaçotempo da obra. O terceiro tema consiste na contextualização da discussão do site-specific a partir do entendimento de como se organiza o espaço na vida contemporânea, conduzindo a uma nova abordagem do site que se especializa em arte —o "cubo-branco"-, ao qual minha produção responde através da conceituação do site-specific deslocado. Finalmente, ao tratar de uma obra de caráter ficcional —um projeto de criação de um ambiente "desviante" no espaço público—, a tese propõe a discussão da experiência do sujeito como navegador, baseada na análise crítica da experiência de navegação na internet, uma nova fronteira da experiência espaço-temporal que se constitui em analogia com o espaço do mundo, tal como o percebemos. 


\section{ABSTRACT}

This thesis comprehends the creation of a set of works of art that allow an experience of spatio-temporal dislocation within the art context, in order to allude critically to the experience of passage observed within the context of contemporary urban space. These works, produced with different means and materials, were presented in the period spanning from 1995 to 2000 and aim at constituting themselves as disturbing elements to destabilize the notions which have traditionally defined sculpture, the relation between the work of art and the spectator and even the architecture that serves as its support.

While considering these questions many themes have emerged. The first is the relation between art and design, which is tense in the works involved, and leads to an experience which is defined in the thesis as "the subjective conflict". The second is the theme of the amplification of the senses through a sinaesthetic experience which generates changes in the landscapes of the (art) world, and in the subject's perception of himself/herself when submitted to the work's space-time. The third theme consists of the contextualization of the discussion about the site-specific through the understanding of how the space of contemporary life is organized; this leads to a new approach of the site that specializes itself in art - the "white cube" —, to which my work responds through de concept of the dislocated sitespecific. Finally, while dealing with a work of fictional nature - a project for the creation of a "deviant" environment in public space-, this thesis brings forth a discussion of the experience of the subject as a navigator, based on a critical analysis of the experience of navigating within the internet, a new frontier for the experience of space-time, which constitutes itself as an analogue to the actual space as we perceive it. 
Para João, Gaspar e Ina. Para Daniela, Murilo, Pompéia, Laura, Paulo, David e João Pedro. Para Maria. Para João Fjeld. Para Lucca, Yunos, Isabella, Mateo e Rafaela. Aqueles que poderão ver mais do que eu. 


\section{AGRADECIMENTOS}

À minha família, em especial a David e Pompéia, a Marcelo e Gláucia, ao Cássio, ao Fred e Francis ao Bernardo e Heloisapelas dicas, pela ajuda e pela confiança. Ao Martin agradeço pelo entusiasmo com o trabalho, pelas críticas e desafios oportunidade rara.

Agradeço ao LSI, Laboratório de Sistemas Integráveis da POLIUSP, em especial a Carlos Eduardo Nogueira e Ruggero Andrea Ruschioni pelo desenvolvimento de "Estação II", e também a Pedro Perez Machado, que, no NICA-ECA, deu início a esse projeto; ao Studio Turtle Skull, em especial a Eduardo Tibira, pela produção do áudio; à Radio Eldorado e ao repórter aéreo Jair Rafael que cederam suas gravações; à Luciana Martins e Gerson de Oliveira, designers e ao Ricardo Heder, da Luminárias Reca. A produção das obras não poderia ter sido realizada sem o apoio de várias empresas. Assim agradeço à Acesita Aços Especiais, Metalúrgica COMISA (Belo Horizonte), Condutron Cadeiras Motorizadas, Divinal, O Estado de São Paulo e Simone Borgas Arquitetura e Design. Agradecimentos especiais à Luciana Brito e Fábio Cimino.

A documentação de toda a produção foi feita pelos excelentes fotógrafos que deixam a memória da obra, agradeço também a todos. São eles: Eduardo Rocha, Eduardo Brandão, Mauro Restiffe, Rômulo Fialdini e Rubens Mano.

Agradeço ao Arão, assistente de todas as horas, pela dedicação e competência.

Finalmente, um agradecimento mais do que especial e uma homenagem à Regina Silveira, que é para várias gerações um exemplo ímpar. Com maestria, desde que iniciou sua carreira, "desbrava" o cenário cultural brasileiro, lutando incansavelmente para constituir um contexto profissional para a produção artística. Sua contribuição para o fortalecimento das instituições de arte tem sido exemplar. Orientou e orienta formal e informalmente muitos artistas. À Regina, minha sincera gratidão por uma orientação sempre precisa, de vida inteira. De você ouvi: "para ser artista, mulher, no Brasil, você precisará levantar duas bandeiras todos os dias de sua vida" (frase dita no atelier de xilo da Faap, em 1980, quando nos conhecemos). 


\section{ARMADILHAS PARA OS SENTIDOS: UMA EXPERIÊNCIA NO ESPAÇO-TEMPO DA ARTE}


A arte como pura auto-expressão não me interessa muito. Inevitavelmente a auto-expressão se embrenha na arte - mas eu preferiria que ela se infiltrasse por alguma porta dos fundos. Para mim, a arte torna-se viva somente quando ela oferece uma estrutura teórica para questionamentos. A ciência oferece essa estrutura teórica também, mas para mim a "boa ciência" é por demais restritiva. Eu preferiria fazer perguntas que se endereçassem simultaneamente a múltiplos mundos — dos organismos vivos até a cultura, a ferrugem e o caos. Somente a arte pode me dar essa generalidade.

Norman T. White 


\section{ÍNDICE}

1 APRESENTAÇÃO $\quad 01$

2 Percurso para a Conceituação da PeSQuisa 04

2.1 Dos desenhos murais aOS aparelhos e estruturas: Conceitos, tÉCNicas E MATERIAIS

3 RefERÊNCIAS PONTUAIS NA PRODUÇÃO QUE ANTECEDE À PESQUISA 12

3.1 A obra como experiênCia de passagem: "Duas Nottes de Sol", 1987

3.2 O lugar da obra e o lugar do observador: "Bico de Diamante", 1990

3.3 A escultura COMO APARELHO PARA O CAMPO DO CORPO E ARMADIlHA PARA O olhar: "Alguns Pássaros (Those IN Flight)", 1991

\section{ARMADILHAS PARA OS SENTIDOS: A EXPERIÊNCIA NO ESPAÇO-TEMPO} DA ARTE. ESTRUTURAS, APARELHOS E O SITE-SPECIFIC DESLOCADO

4.1 A ESCULTURA COMO ESTRUTURA DE SUPORTE PARA UM CORPO EM TRÂNSITO:

o conflito do sujeito - "Serpentinata", "Belmont Station" e "Rotatórias" 26

4.2 A escultura como aparelho para o Campo do Corpo -

"Alguns Pássaros (Those in Flight)", "Guarda-Corpo", "Visita Guiada COM AMIGO J9. PARA EDEMAR" E "EXIT"

4.3 O SITE, O SITE-SPECIFIC E O SITE-SPECIFIC DESLOCADO: O CONFLITO EXPANDIDO "Gambling", "Porto Pampulha" e "Relax'óvisions"

4.3.1 A EXPERIÊNCIA DO ESPAÇO

4.3.2 A EXPERIÊNCIA DO ESPELHAMENTO

4.3.3 A EXPERIÊNCIA DO NÃO-LUGAR

73

4.3.4 A EXPERIÊNCIA DO SITE AO SITE-SPECIFIC DESLOCADO

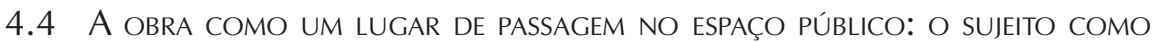
navegador - "Estação Panamericana" e "Estação II"

6 APÊNDICE: FICHA TÉCNICA DAS OBRAS

6.1 Produção Que AnteCede A PeSQuisa (1985-1994) 


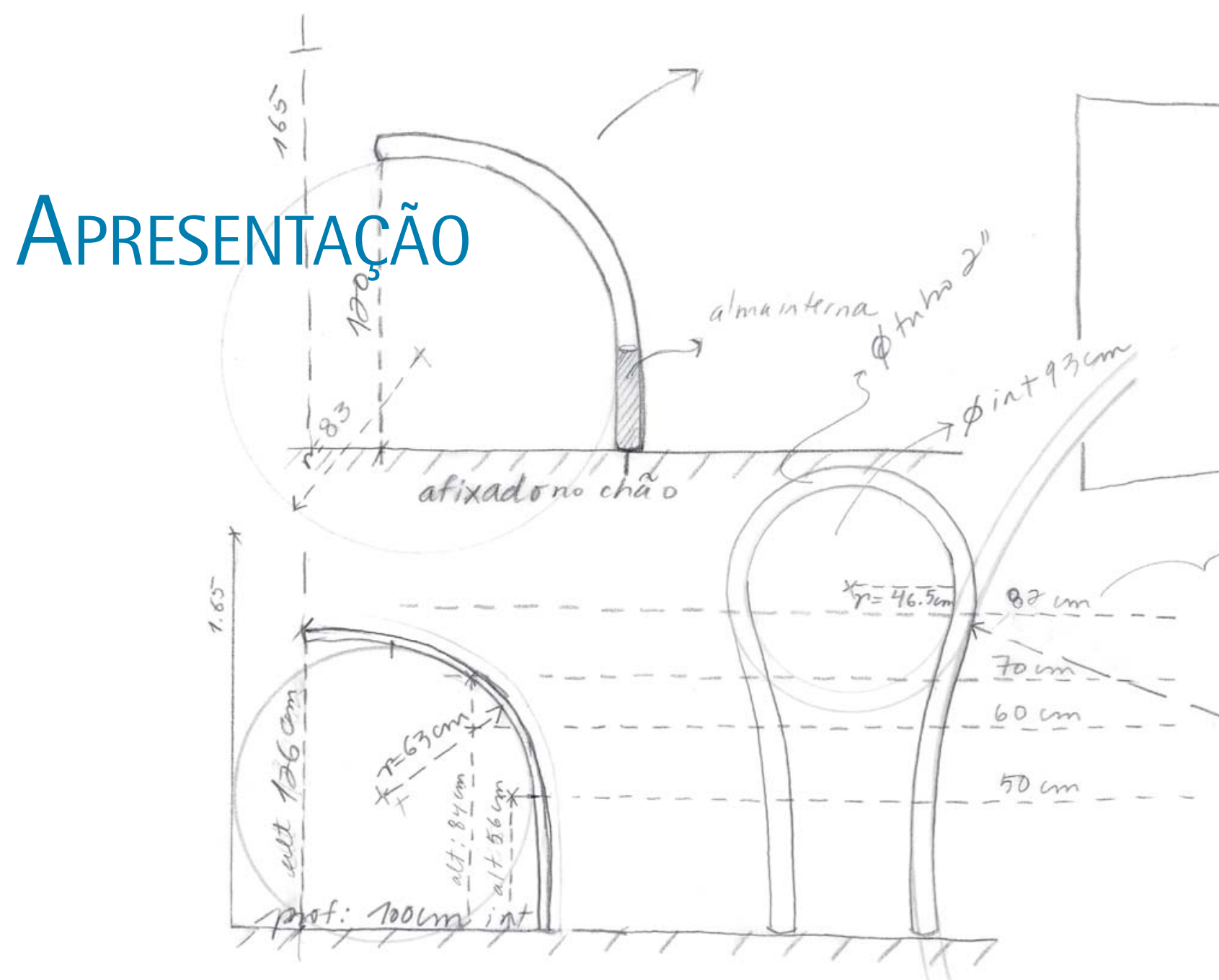


Esta pesquisa de doutorado teve sua origem nas reflexões contidas na obra "Alguns Pássaros (Those in Flight)" realizada em 1991. As direções toma das por este trabalho constam em um depoimento, onde o projeto de estudos já se definira como:

... o projeto pretende que as esculturas tenham como princípio a idéia de aparelhos com a função específica de relocar o espectador. Pretende expandir os vários significados da obra para seu exterior, para o confronto com seu entorno, a fim de que funcionem como aparelhos para o campo do corpo e armadilhas para o olhar

Desde então o trabalho artístico se expandiu, buscando aprofundar os conceitos inerentes àquela proposta inicial, bem como incluir aqueles advindos de outras áreas do conhecimento. Consequentemente, expandiu-se o escopo de todo o trabalho, inclusive no que diz respeito à reflexão teórica e aos objetivos estéticos implicados em sua produção.

Contudo, esta ampliação só foi possível na medida em que se passou a observar, no contexto da vida contemporânea, situações análogas àquelas que estavam sendo propostas nas obras realizadas até então. Entre elas, as mais relevantes à pesquisa se referem à condição de passagem do indivíduo contemporâneo e ao trânsito que caracteriza o seu contexto, questões essas que já fundamentavam obras anteriores.

O estudo e o entendimento das abordagens teóricas que analisam as transformações na vida contemporânea e o homem como um ser de passagem passaram a iluminar as discussões intrínsecas às obras e suas referências no terreno da arte. Além disso, a noção de relocar o observador passou a ser a principal estratégia da produção e recurso fundamental para discutir o espaçotempo do observador/passageiro dentro do sistema da arte.

1 Trecho extraído do projeto apresentado para ingresso no programa de Pós Graduação da ECA/USP em 1995. 
As formulações teórico-conceituais presentes nesta tese derivam, finalmente, de um conjunto de quarenta e sete obras exibidas em dez exposições (4 individuais e 6 coletivas $^{2}$ ), realizadas no período de 1995 a 2000. As características comuns a essas obras permitiram-me nomear esse conjunto como Armadilhas para os Sentidos: Uma Experiência no Espaço-Tempo da Arte.

Nesta tese procuro formalizar o percurso das reflexões que possibilitaram sua realização, no contexto de minha produção artística recente.

2 As individuais: "Rotatórias" (1996), "Porto Pampulha" (1997), "Relax'o'visions"(1998) e "Estação II", (2000); e as coletivas: "Entre o Desenho e a Escultura" (1995), "Arte e Espaço Urbano: Quinze Propostas" (1996), "Ao Cubo" (1997), "Il Semana Fernando Furlanetto: Fotografia"(1999), "Território Expandido", (1999), "Panorama 99" (1999). A ficha técnica das obras expostas está detalhada nas páginas 81 a 93. Com exceção de "Estação II", ainda inédita na ocasião da defesa desta tese, todas as obras foram produzidas e expostas publicamente durante o período de realização da pesquisa. 


\section{Percurso para a conceituação DA PESQUISA}
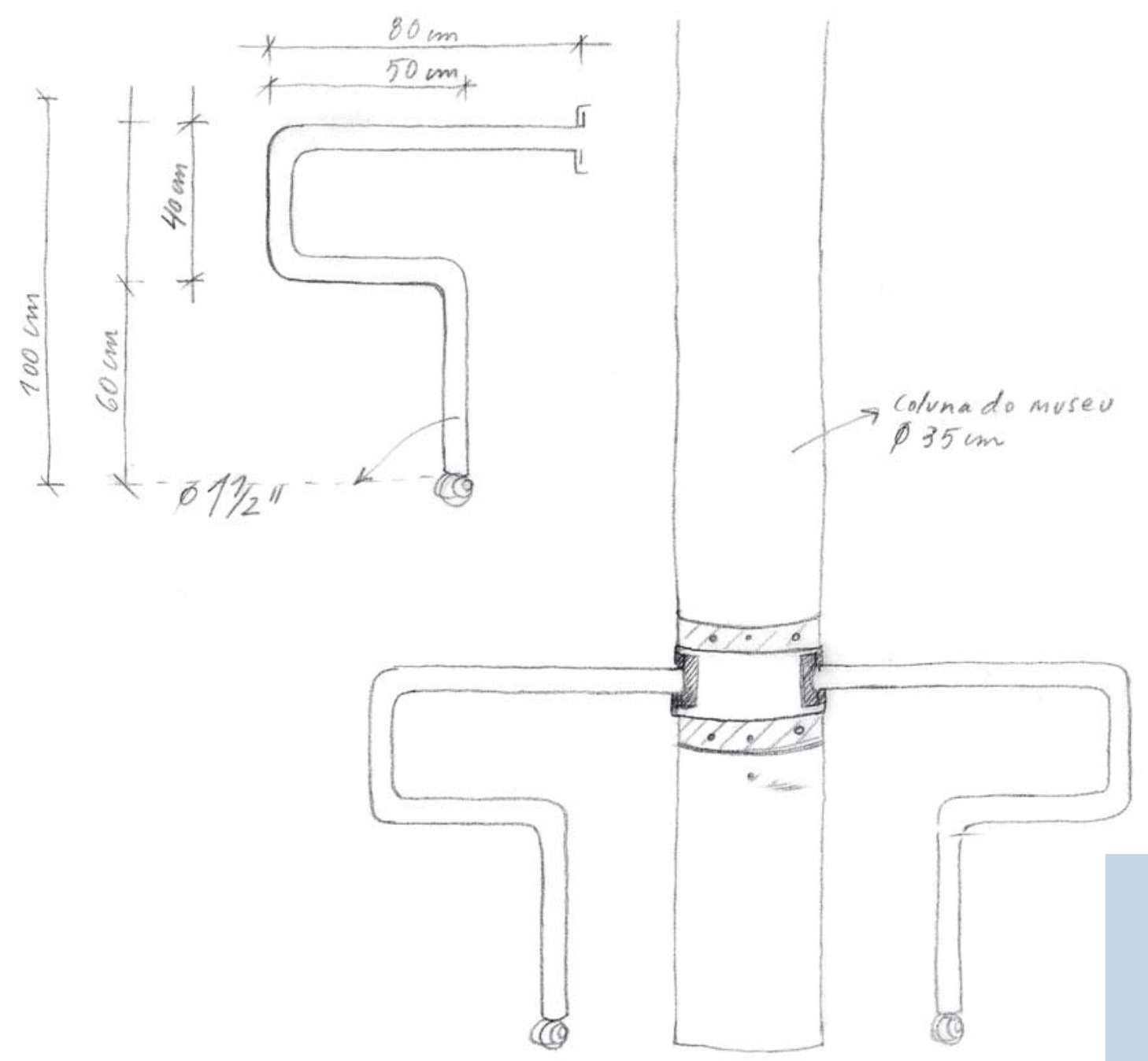
Otrabalho de pesquisa nasce de indagações germinais: a quem a obra se dirige? quem é o seu sujeito? Enfocar essas questões significou não só incluir o que é próprio da subjetividade do artista, mas, sobretudo, estar consciente do sistema no qual a arte se insere. Desde o início, as formulações provocadas por essas indagações estiveram sustentadas pela observação atenta do contexto da vida contemporânea e se nutriram do interesse por determinados momentos da História da Arte, moderna e recente, mais especificamente aqueles que produziram significativas transformações no entendimento da função, do uso e do lugar da arte.

No contexto de tais questionamentos não caberia privilegiar a produção de objetos estéticos com direcionamento apenas formal, isolados de seu entorno ou da experiência do fruidor. Ao contrário, o percurso da reflexão ligada a minha produção levou à constatação de que a resposta tem como condição, em primeiro lugar, uma abordagem da arte do ponto de vista da experiência, não só da própria obra e de seu espaço de inserção, mas também a experiência contemporânea do sujeito imerso no contexto urbano.

\subsection{Dos desenhos murais aOS aPARELHOS E estruturas: Conceitos, TÉCNICAS E MATERIAIS}

Em seu desenvolvimento, o trabalho cumpriu uma trajetória, sempre caracterizada pelo diálogo com o desenho, o design e a arquitetura.

A produção realizada de 1982 até 1984 procurou enfocar o confronto do espectador com a obra, enfatizando a necessidade de um deslocamento físico para a total apreensão do trabalho proposto. A situação arquitetônica, seja ela dada ou construída para o trabalho, funcionava como suporte e fonte de inspiração para as obras criadas. 
Nos desenhos-instalações elaborados em Chicago entre 1985 e $1986^{3}$, o registro do gesto, obtido através da sobreposição de linhas contrastantes, contribuia para o surgimento de formas densas que sugeriam, através de seus volumes vazados, uma ação dinâmica no plano das paredes. A noção de desenho estava aqui submetida, em primeiro lugar, à consciência de um determinado espaço arquitetônico. Ao pensar a arquitetura como suporte para os desenhos murais, pressupunha-se considerar um outro tipo de expressão gráfica: o desenho arquitetônico que estrutura e define o espaço como ambiente. Com essas premissas, a obra se definiu a partir das particularidades dos ambientes escolhidos e da elaboração de uma trama linear constituida pela sobreposição de gestos repetidos. O aperfeiçoamento da técnica para a realização dos desenhos exigiu a confecção de lápis especiais e o uso de tintas de diferentes qualidades. Foi possível assim a obtenção de tramas cada vez mais densas, que transformavam a superfície plana da parede em espaços profundos, onde o agigantamento das formas tornava a experiência antes intimista do desenho em confronto do observador com o espaço. Nessas instalações a linha negra do desenho já manifestava sua vocação tridimensional e a possibilidade de sua tradução para o espaço real.

A passagem do desenho bidimensional realizado sobre paredes para o desenho no espaço implicou a escolha de materiais que pudessem traduzir as características gestuais até então presentes no trabalho. Esta etapa exigiu um aprofundamento no conhecimento dos materiais e ainda o aprendizado e o domínio de novas técnicas para a manipulação de metais (alumínio, aço carbono, inox e madeira, entre outros). Em 1986 foram realizadas as primeiras peças em aço carbono polido para serem organizadas sobre as paredes desenhadas. O objetivo aqui era efetivar a passagem das várias camadas de uma trama densa, originada na superfície da parede, para uma outra, constituída pela sobreposição de esculturas lineares no espaço real. A insatisfação com o

3 "Cantos", Oxbow, Michigan, 1985; "Sem Título", SAIC, Chgo, 1985, "Running Wall", Superior Street Gallery, Chgo, 1986, "Untameable Pocket", SAIC, Chgo, 1986, "North and South", SAIC Chgo, 1986. Essas obras foram realizadas durante os de dois anos do mestrado em Chicago (1984-86). 


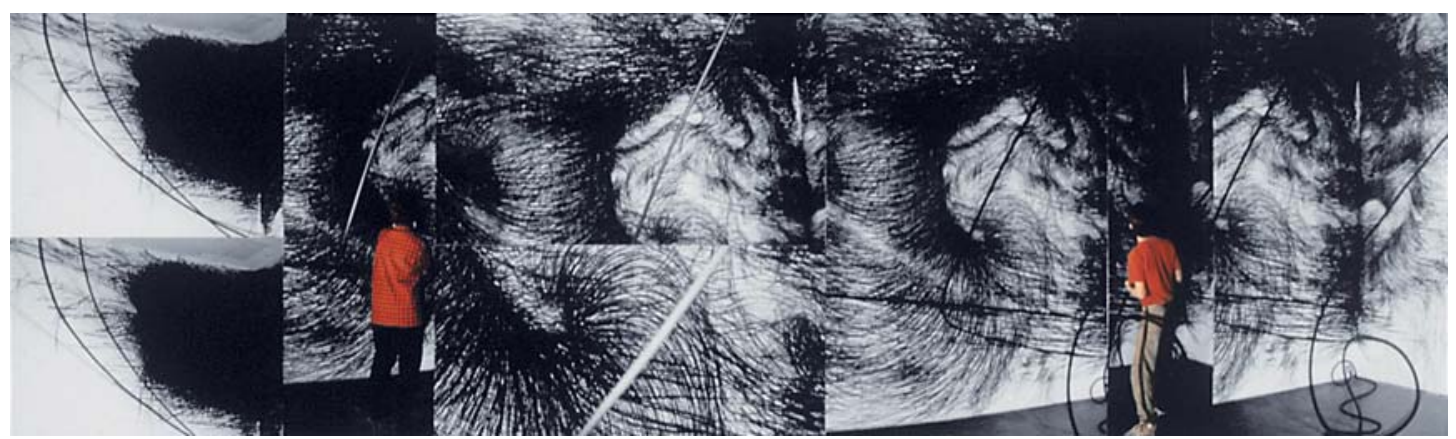

fig. 1 - "Sem Título", 1985

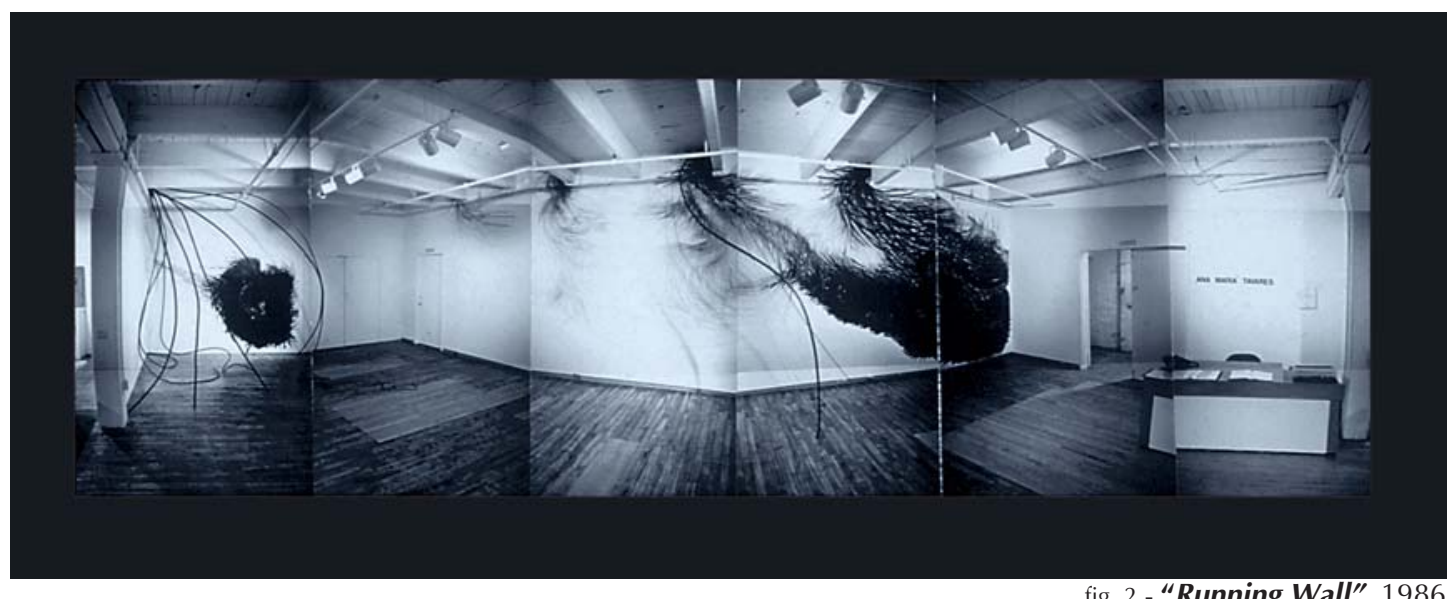

fig. 2 - "Running Wall", 1986

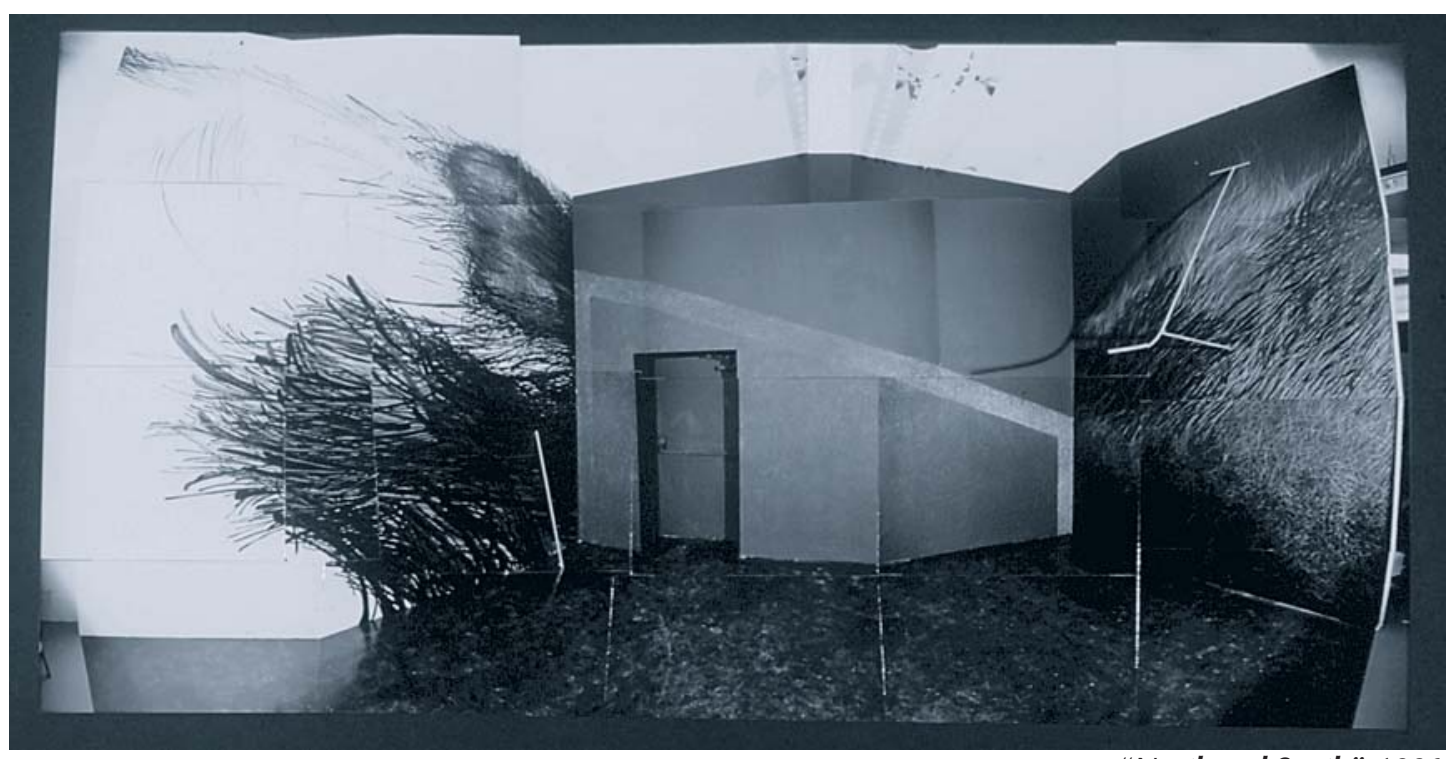

fig. 3 - "North and South", 1986 
resultado desta operação deu início a uma reflexão intensa acerca da conceituação da escultura como desenho no espaço.

Nesta ocasião, as esculturas em madeira, ferro e bronze de Júlio González (1876-1942), Pablo Picasso (1881-1973), Alberto Giacometti (1876-1966) e David Smith (1906-1965) foram exemplares para a autocrítica desses trabalhos ${ }^{4}$. Em especial interessava-me a noção de escultura como desenho no espaço, que aparecera inicialmente nas experimentações, em parceria, de González e Picasso. Usando técnicas de soldagem de metais (aprendidas durante os anos da I Guerra Mundial quando trabalhou na Renault), González aprimorara sua habilidade de criar peças mais delicadas e estáveis. A produção desses dois artistas significou uma grande mudança para o pensamento escultórico pois, através do emprego de arames e tarugos de ferro, das sobras de materiais e de objetos do cotidiano, González e Picasso conceberam esculturas lineares, transparentes e abertas. O objetivo de González, em suas próprias palavras, era o de "projetar e desenhar no espaço com a ajuda de novos métodos" e "utilizar esse espaço e construir com ele, como se estivéssemos lidando com algum material recém adquirido - nisso se resumem todas as minhas tentativas" ${ }^{5}$. Desta forma o espaço era transformado em elemento constituinte da obra e o desenho no espaço transformava em obra o que antes era entendido como estrutura.

De 1989 em diante dei prioridade à produção de uma série de esculturas centradas na idéia de estabelecer uma relação tensionada entre o universo dos objetos utilitários e um universo mais subjetivo, próximo à natureza do desenho expressivo, representado no trabalho por linhas de caráter convulsivo e muitas vezes desordenado. Essas esculturas, que aludiam a objetos do cotidiano, como os móveis e os utensílios domésticos, pretendiam apresentar duas possibilidades do desenho no espaço: aquela que remete a um programa

${ }^{4}$ Essa reflexão teve início em 1985, durante o mestrado na escola The School of The Art Institute of Chicago, EuA.

${ }^{5}$ Andrew, Ritchie C. Apud Krauss, Rosalind E. "Um Plano de Jogo: os termos do surrealismo" in Caminhos da Escultura Moderna São Paulo: Marins Fontes, 1998, p. 159. 
que é definido por sua função, ou seja, o design, e outra, da pura expressão do gesto que ativa o espaço. A fusão desses dois modos do desenho iria configurar um objeto híbrido que propunha ao mesmo tempo a reflexão a respeito da condição efêmera e transitória da obra, do gesto do artista e da experiência do observador, aspectos de extrema relevância no desenvolvimento posterior do trabalho.

Apesar de incorporar o design enquanto princípio estruturador da forma, os objetos criados subvertiam as noções de função, com a intenção de causar uma perturbação na sua experiência e de sugerir "uma irritante consciência de fracasso" ${ }^{\prime \prime}$ : fracasso dos objetos por seus atributos híbridos que os tornam incompetentes e fracasso do espectador, impossibilitado de realizar a função sugerida pela obra. As esculturas-objetos eram também, nesse momento, esculturas-desenho amparadas pelas paredes brancas das salas onde eram instaladas. Ou seja, na medida em que essas obras eram estruturas lineares com acabamento preto-fosco, mantinham uma relação de dependência com as paredes brancas. Nesse sentido, a série composta pelas mesas e plataformas e outras esculturas do mesmo período continham certa ambigüidade pois, se por um lado foram pensadas como esculturas autônomas, por outro ainda mantinham uma clara dependência do plano branco das paredes, revelando ainda as heranças do desenho.

Com a criação do primeiro "beiral"7, em 1990, mudam novamente os termos da relação da obra com a arquitetura e o lugar onde se situa. Não se tratava mais da simples alusão a objetos utilitários. A linha negra no espaço assumia nova configuração, abandonando a tarefa de se caracterizar como um gesto expressivo. Como um elemento arquitetônico, o "beiral" compõe e demarca um limite para o corpo, prevê e determina uma ação específica para seus

\footnotetext{
${ }^{6}$ A "irritante consciência de fracasso" é a uma expressão usada por Maurice Nadeau em 1931, para qualificar a experiência de "Bola Suspensa" de Alberto Giacometti. Apud KRAUSS, Rosalind E. Caminhos da Escultura Moderna. São Paulo: Martins Fontes,1998, p. 137. Tomo emprestada a expressão de Nadeau para ressaltar a importância que o pensamento de Giacometti teve para o desenvolvimento de meu trabalho.

${ }^{7}$ O termo "beiral" é popularmente utilizado no contexto da serralheria artística para designar os guarda-corpos utilizados na arquitetura para proteger e amparar o corpo em varandas, sacadas, mezaninos.
} 
usuários, ampara e protege o corpo.

Introduzido no contexto da escultura, faz com que a ação "distraída" do espectador, que se apoia no "beiral", seja incorporada ao contexto da obra, resgatando-o para dentro dela. Configura-se então como um anteparo ${ }^{8}$ para o corpo e, ao mesmo tempo, lugar para a contemplação de tudo aquilo que se apresenta para o olhar.

O abandono de um pensamento puramente gráfico, que aludia à

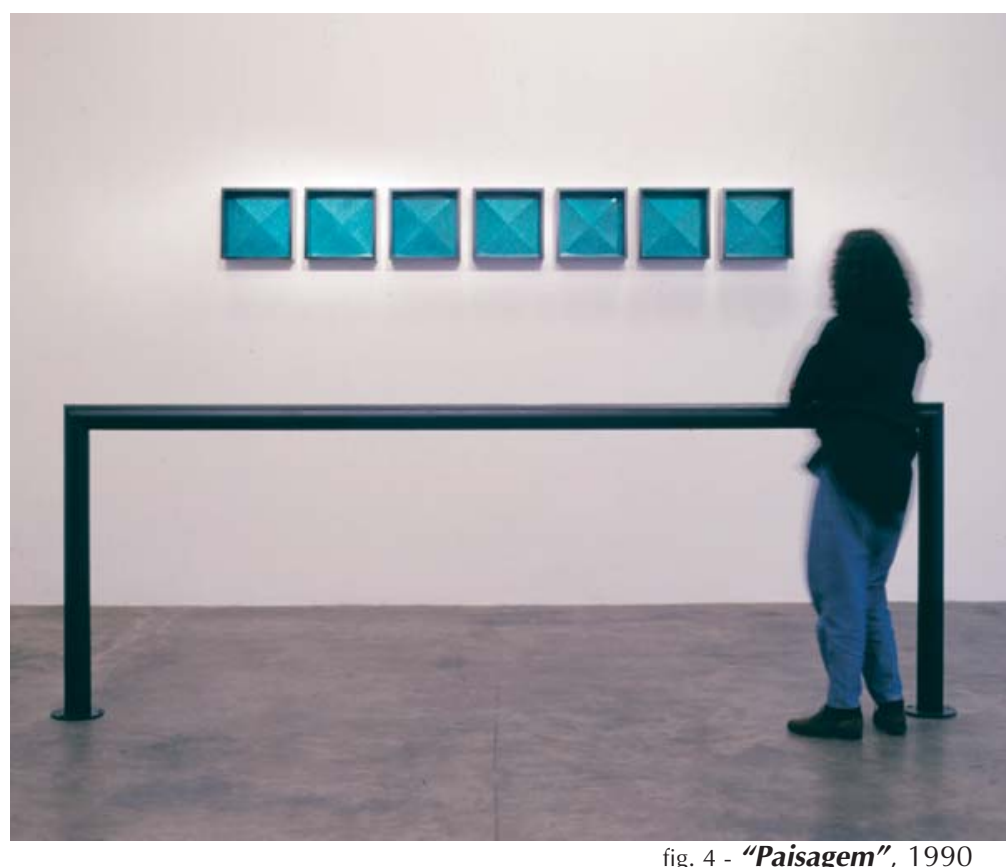

fig. 4 - "Paisagem", 1990 representação no campo bidimensional, em favor de outras especulações, mais próprias ao universo da escultura, foi marcado pela criação dos "beirais" e, posteriormente, de "Alguns Pássaros (Those in Flight)" em 1991. O desenho passou então a ser entendido como programa e a incorporar os métodos de planejamento e produção característicos do universo do design. A partir daí, as esculturas assumiram características de estruturas para o apoio do corpo, apropriadas a partir da observação meticulosa dos espaços públicos, do universo do mobiliário urbano, de hospitais e academias de ginástica, lugares esses que incluem a arquitetura de grandes lobbies, dos aeroportos ou rodoviárias e estradas, entre outros. A consideração destes espaços públicos caracterizados pelo fluxo constante de pessoas, está na base da conceituação das esculturas tratadas como estruturas de suporte para um corpo em trânsito. Esse conceito pressupõe a obra como âncora para um corpo em deslocamento e tem como objetivo a reflexão sobre as relações que este corpo que caminha e se desloca no espaço e no tempo estabelece com os contextos nos quais se insere. Refiro-

${ }^{8}$ Opto pelo uso da palavra "anteparo" ao invés de, por exemplo, "escora", para salientar que o "beiral" tem a função de proteger o observador de uma imediata dissolução na obra, o que seria o equivalente à empatia. A presença do "beiral" é essencial para detonar a consciência do ato de fruição da obra. 
me aqui a dois contextos em particular: o contexto urbano, habitado pelos "usuários" em trânsito, e o da arte e suas relações com o observador. A superposição dos dois dá origem à pesquisa nucleadora desta tese, que trata de pensar, através da produção artística, o indivíduo em seu tempo, e que acaba por localizar, na vida contemporânea, as questões que conduzem à conceituação do homem como um ser de passagem e, enfim, a objetos de arte que pretendem funcionar como armadilhas para os sentidos. 
REFERÊNCIAS PONTUAIS NA

PRODUÇÃO QUE ANTECEDE À

PESQUISA

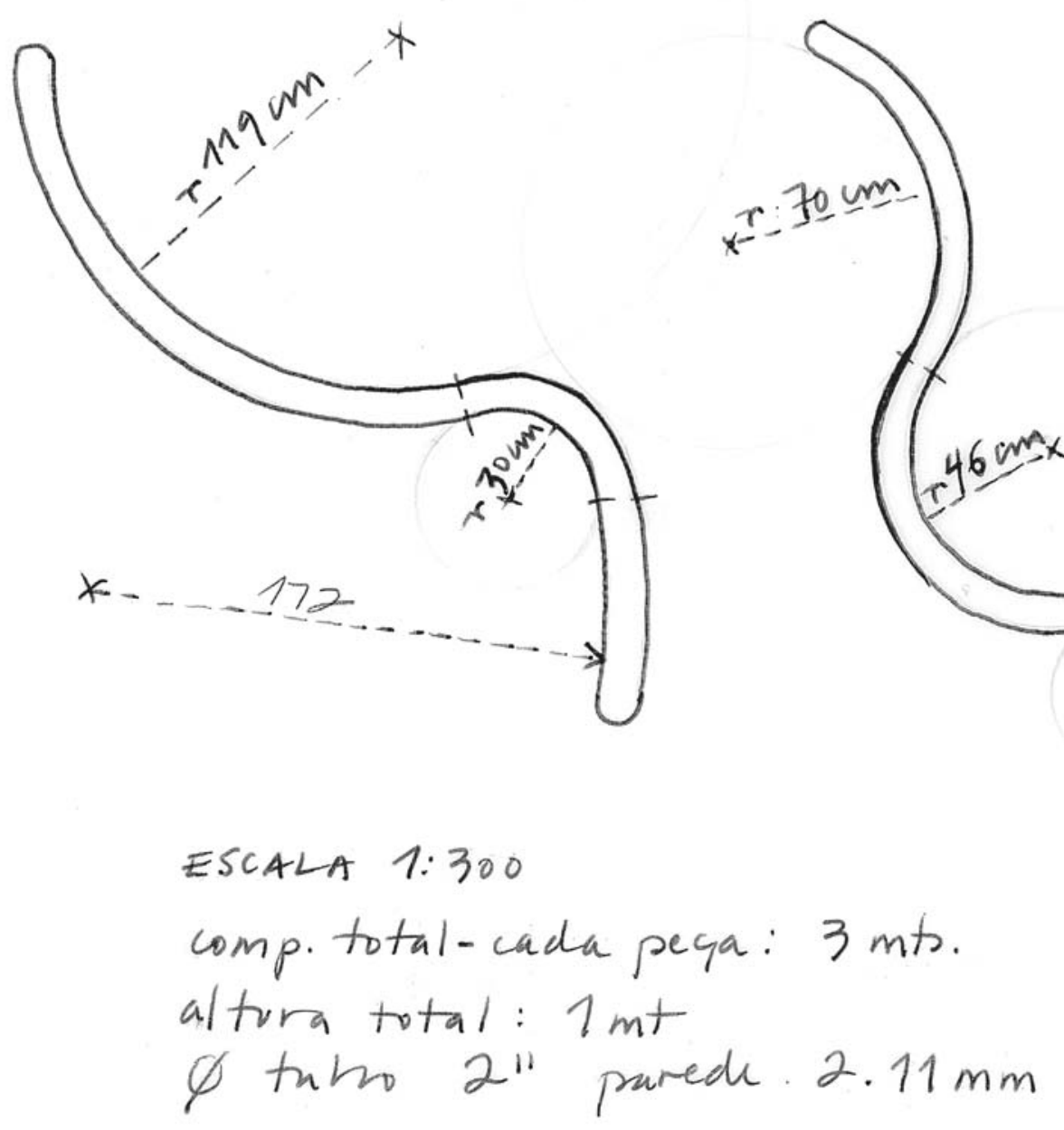


Três obras realizadas entre 1987 à 1991 podem fornecer referências mais próximas aos conjuntos de esculturas que constituem o corpo desta pesquisa. "Duas Noites de Sol", 1987, onde se efetua a transição do conceito de observador para o de passageiro/viajante; "Bico de Diamante", 1990, onde, pela primeira vez se demarcou o lugar do observador no momento de fruição da obra e "Alguns Pássaros (Those in Flight)", 1991, que, finalmente, revelou a possibilidade de atribuir à escultura a função de aparelho para o campo do corpo e armadilha para olhar.

\subsection{A obra como experiência de passagem: "Duas Nottes de Sol", 1987}

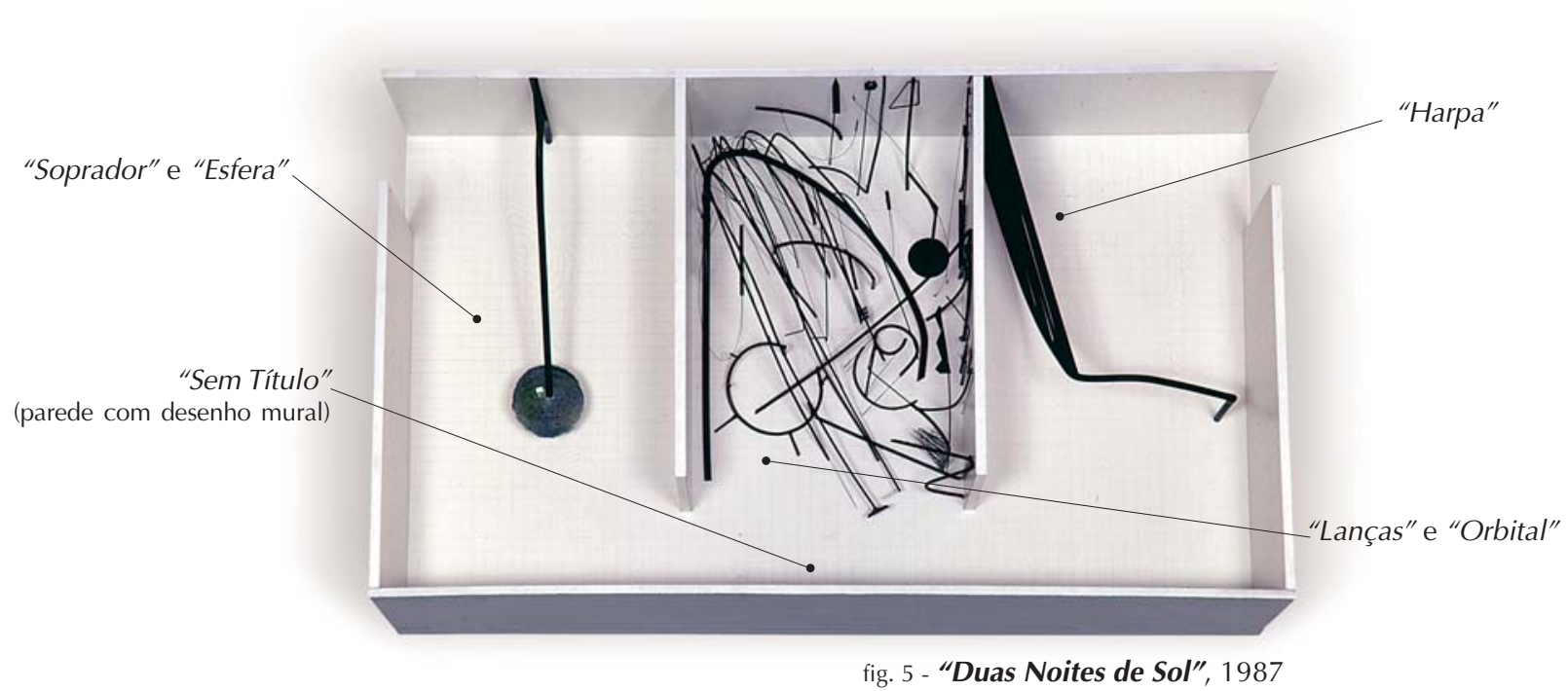

"Duas noites de Sol" foi concebida com o objetivo de conduzir o espectador a uma experiência de deslocamento espaço-temporal, explicitando a obra como lugar de passagem. A instalação abrigava três salas com esculturas, bem como um desenho mural ao longo do corredor que interligava os três ambientes. $\mathrm{O}$ primeiro era constituído pela escultura "Harpa", que se projetava em arco e 

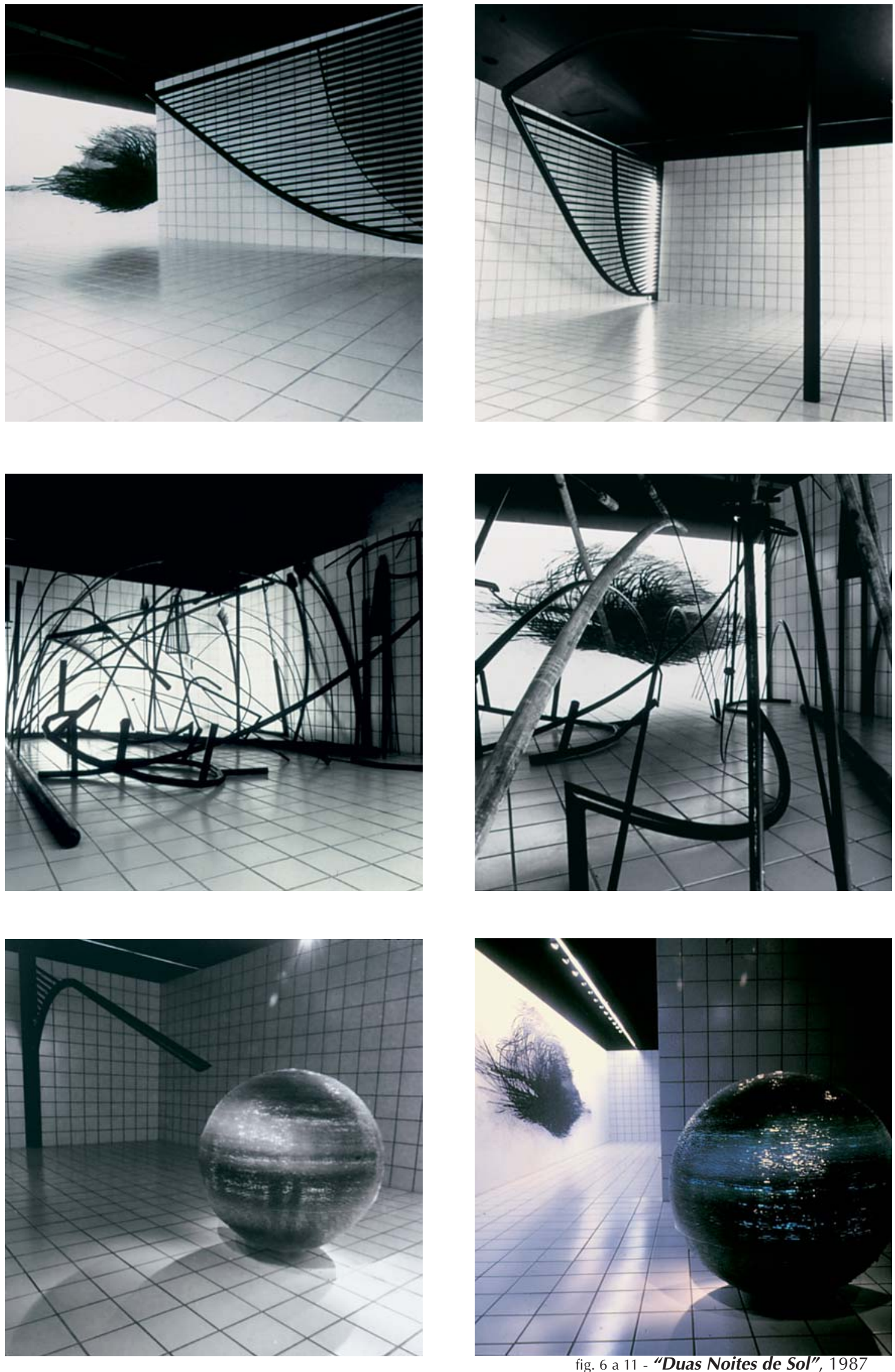
introduzia o espectador aos espaços subsequentes. Na sala do meio, "Lanças" e "Orbital" ocupavam todo o ambiente, dificultando a entrada e a interação do visitante, a fim de propor uma experiência puramente visual. Em percurso de uma única direção, o visitante alcançava a última sala com "Soprador" e "Esfera". Enquanto as linhas aparentemente desordenadas do desenho e das esculturas pareciam se projetar convulsivamente no espaço e na superfície da parede, estabelecendo um contraste com a malha reticulada das lajotas cerâmicas, "Esfera" e "Soprador" proporcionavam uma experiência de repouso e de contemplação, ocasionada pelo emprego da luz e da qualidade dos materiais escolhidos. O visitante, ao realizar o seu percurso, passava à condição de passageiro, viajante: aquele que, através do deslocamento físico, percorria o espaço-tempo da obra.

Aqui estaria talvez uma das origens da idéia de relocar o observador. Ao adentrar a instalação o visitante percorria um espaço subjetivo e, ao mesmo tempo, auto-referente, colocando o espaço institucionalizado da Bienal temporariamente em suspensão. Porém, se por um lado a obra concretizava a experiência do observador como passageiro e proporcionava uma suspensão do espaço-tempo real, por outro, o excesso de subjetividade e auto-expressão se revelaram, posteriormente, como desvios indesejáveis.

"Duas Noites de Sol" marcou um momento de transição importante para o trabalho, ao apontar a necessidade premente de repensar, de maneira crítica, a instalação e a escultura, a fim de ampliar os significados que esses modos de produção poderiam ainda gerar. Um primeiro passo tomado nesse sentido foi o de priorizar a produção de objetos autônomos, isto é, de obras que não estabelecessem uma dependência da arquitetura. Tornou-se então essencial sublimar estrategicamente o espaço do "cubo branco"9, transferindo as significações deste campo arquitetônico para o da própria obra, e assim criar

\footnotetext{
9 "Cubo branco" é uma expressão que denota o espaço idealizado para constituir o lugar da arte. As suas implicações serão discutidas nas páginas 60-68, tendo como referência, principalmente, o livro de Brian O'DOHERTY, intitulado Inside the White Cube: The Ideology of the Gallery Space (San Francisco: The Lapis Press, 1986).
} 
uma escultura que fosse em si mesma um lugar: a plataforma, o palco, o tableau ${ }^{10}$.

Ao conceber a escultura como tableau, pretendia fazer com que a obra se constituísse como um lugar que mantivesse o observador à distância, para inviabilizar a experiência física sugerida e privilegiar apenas a fruição através do olhar. Tomo como primeiro exemplo desta passagem a obra "Aquário", pertencente à série Mesas, formada por esculturas que são plataformas suspensas por pernas alongadas com rodas industriais, à altura média do olhar. Sobre essas plataformas foram organizados tarugos de alumínio anodizado em diversas configurações sugestivas, quando relacionadas com seus títulos: "Mesa Curva", "Aquário", "O Beijo"11. Pretendia-se aqui estabelecer o contraste entre as referências do universo objetivo do espectador, evidenciado na escultura pela forma de objeto utilitário (a mesa com rodas) e um outro universo, mais subjetivo, emoldurado e ativado por filetes de alumínio que remetiam ao desenho. Porém, é importante ressaltar que, na série mesas, as rodas cumpriam um papel de grande importância na medida em que sugeriam, mesmo que metaforicamente, o suposto deslocamento do desenho mural para o espaço real. O caráter "móvel" conferido à obra
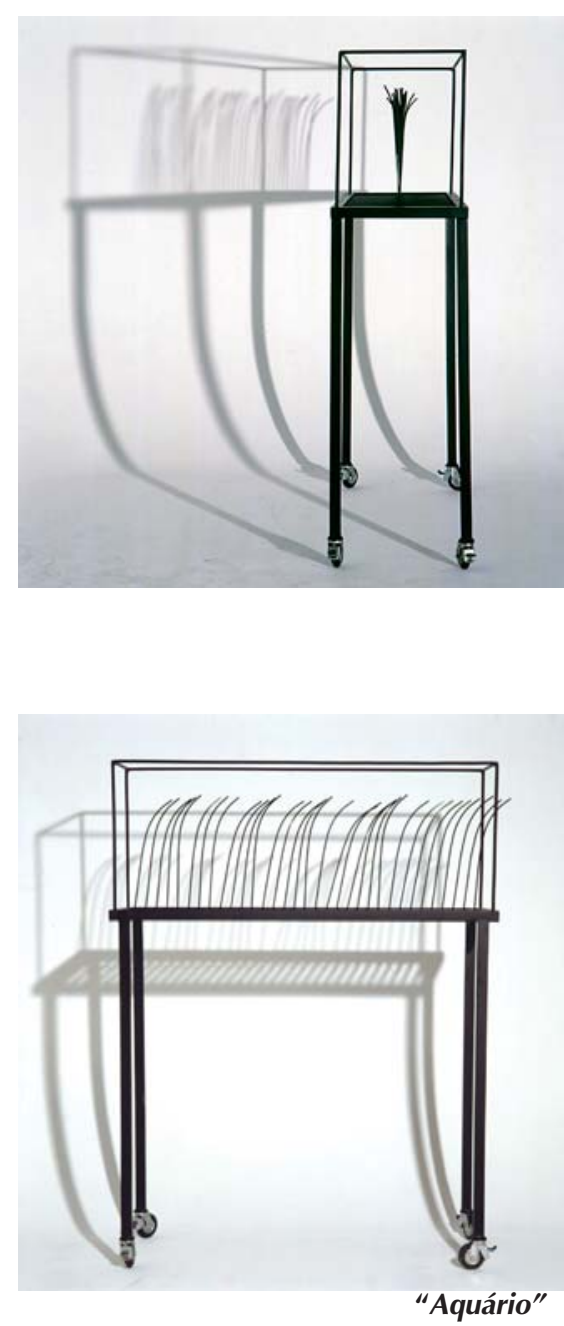

fig. 12 e 13 - série "Mesas",1989

\footnotetext{
${ }^{10}$ Esse termo alude à pintura tradicional ilusionista (representação fiel de um espaço real) que constitui um espaçotempo autônomo, proporcionando ao espectador uma experiência distanciada. O'DOHERTY faz uma interessante relação entre esse tipo de pintura e as instalações dos anos sessenta. Para ele, a "collage ambiental e a assemblage se esclarecem com a aceitação do tableau como gênero. Com os tableaux (Segal, Kienholz), o espaço ilusionista contido na imagem tradicional é realizado na caixa da galeria. A paixão para realizar inclusive a ilusão é a marca —até um estigma— da arte dos anos sessenta". (O'DOHerTy. Opus cit., p. 49). Porém, no contexto da minha produção não se trata da alusão a uma experiência ilusionista tornada real, mas da constituição de um outro espaço-tempo distanciado do espectador — nesse sentido ela se aproxima menos da arte dos anos sessenta que da pintura ilusionista tradicional, só que sem o ilusionismo.

${ }^{11}$ Obras criadas para Arte Híbrida, exposição coletiva com a participação de Sérgio Romagnolo (curador), Mônica Nador, Leda Catunda e Ana Maria Tavares em 1987, no Rio de Janeiro, São Paulo, Porto Alegre e Caxias do Sul.
} 


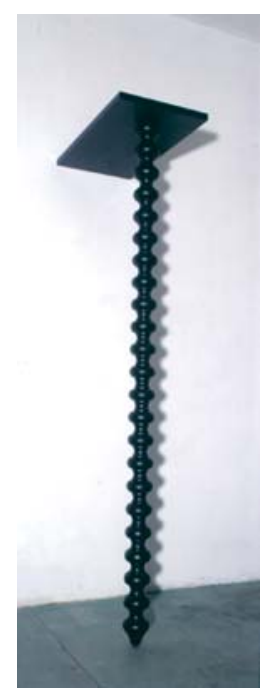

"Plataforma"

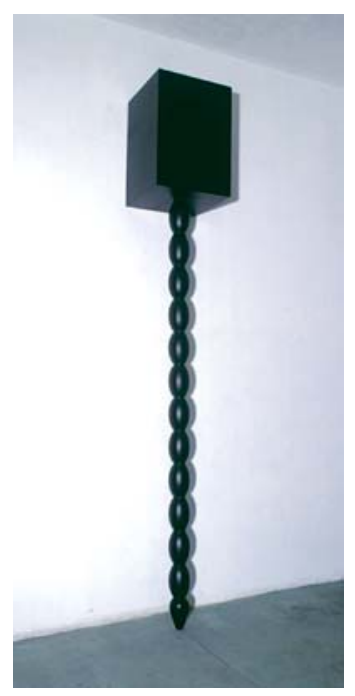

"Logbook/Caixa Preta"

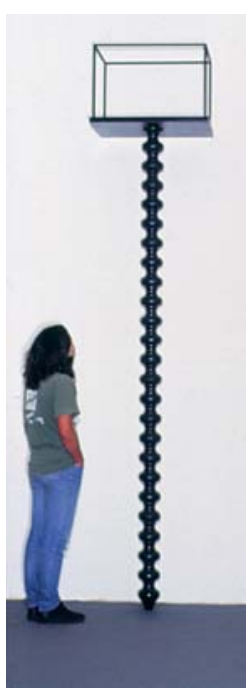

"Container"

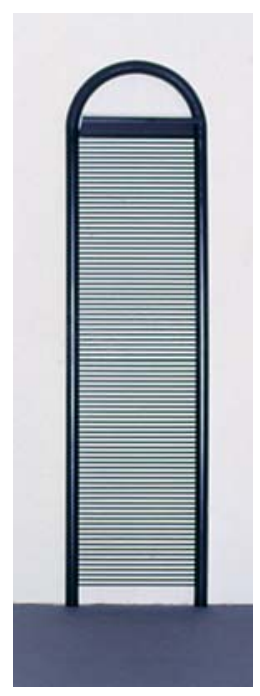

"Escada" fig.14 a 17 - série "Plataformas",1991

pela presença das rodas pretendia sinalizar o forte desejo de fazer com que o trabalho assumisse, mais definitivamente, sua condição tridimensional. Desta forma, elas poderiam ser entendidas como um comentário irônico e até bem humorado, a respeito da autonomia da obra e de sua permanência no contexto da arte.

A conceituação da escultura como um lugar distanciado e, ao mesmo tempo ativo em relação ao universo do espectador, nutre-se dos conceitos de algumas obras dos artistas surrealistas, mais especificamente as de Alberto Giacometti. Tratando a obra como uma "projeção do desejo", Giacometti pensa a escultura como uma imagem pronta. Nas séries "Gaiolas" e "Tabuleiros", Giacometti subverte a relação de espaço-tempo na medida em que cria pequenos ambientes que se caracterizam como "outros" territórios descolados do espaço tempo do observador. Estes, por sua vez, são interrompidos pela inclusão do movimento literal e do tempo real, como nota Rosalind Krauss: "ao mesmo tempo em que seu movimento é obviamente literal, seu lugar no mundo está confinado ao palco especial de uma gaiola- está isolado das coisas à sua volta ${ }^{12}$.

\footnotetext{
${ }^{12}$ Krauss, Rosalind E. Opus cit., pp. 137-138.
} 
Assim, nesta etapa, passei a considerar a escultura não apenas como uma suspensão espaço-temporal mas, concordando com KRAUSS, como uma "fenda na realidade contínua do espaço" ${ }^{\prime 13}$, e a obra como um lugar aberto para as projeções subjetivas do espectador. As esculturas da série plataformas ( "Container", "Escada", "Plataforma" e "Logbook/Caixa Preta") são exemplos de obras que pretendem explicitar essa experiência. Em todas elas é imediato o reconhecimento de um objeto de uso, porém fica simultaneamente patente a sua inviabilidade funcional. São ambientes elevados a uma altura de três metros e meio do chão ${ }^{14}$, lugares inacessíveis ao corpo, acessíveis apenas ao olhar.

Posso finalmente resumir assim a significância desses trabalhos: "Duas Noites de Sol" (1987) já trazia em si a possibilidade de explorar a experiência do espectador como uma experiência relativa à passagem e ao trânsito. No entanto —é importante ressaltar_, somente a partir de "Alguns Pássaros (Those in Flight)" (1991) essa possibilidade pôde consumar-se. Isso porque era necessário, antes, desfazer-me do excesso de subjetividade que ainda pesava sobre o processo de concepção das esculturas (e de sua organização) em "Duas Noites de Sol", o que só foi possível depois dos experimentos de distanciamento (inclusive físico), implicados na proposta da escultura como tableau. Nesse período a obra se abriu e se tornou lugar para a projeção de uma subjetividade que não era mais tanto do artista quanto do espectador.

\footnotetext{
${ }^{13}$ Idem, p. 139. Expressão usada por KRAUSS, tratando dos escultores surrealistas, que define a experiência de descontinuidade do espaço e do tempo na obra de GIACOMETTI.

${ }^{14}$ A prateleira, em "Escada", a plataforma, em "Plataforma", a caixa vazada, em "Container" ou caixa lacrada, em "Logbook/Caixa Preta".
} 


\subsection{O lugar da obra e o lugar do observador: "Bico de DIAMANTE", 1990}

A obra "Bico de Diamante"15, idealizada para a exposição "Apropriação de Espaço" no Paço das Artes, pretendia criar um tensionamento entre o lugar demarcado para o espectador e o lugar destinado para a "obra". A primeira era composta por um "beiral" que dividia o espaço e demarcava um suposto território de domínio para o visitante posicionado à distância daquilo que deveria

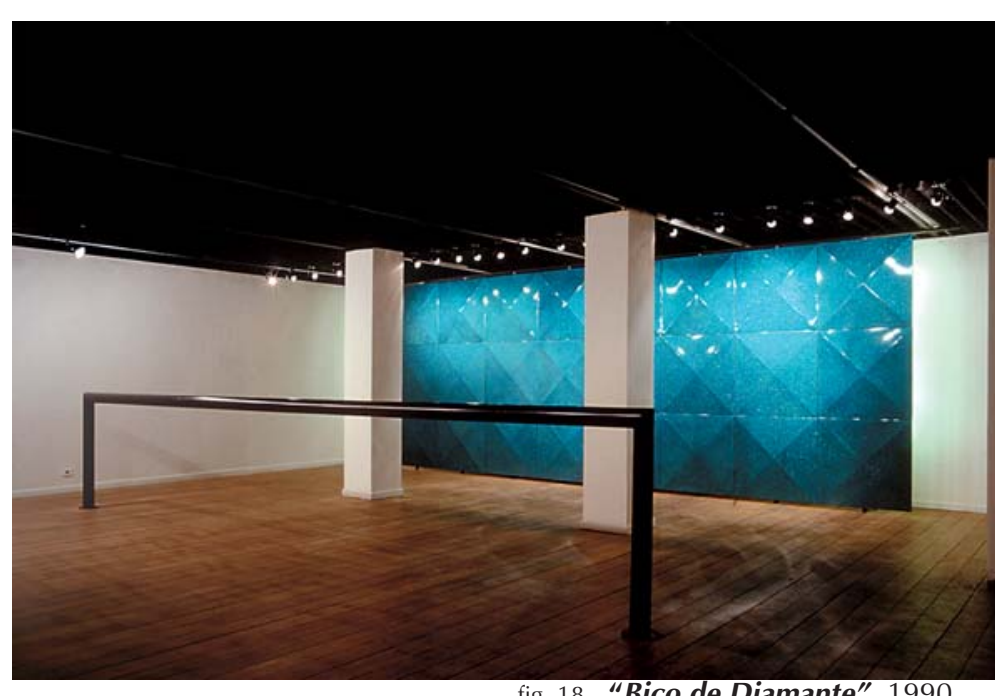
contemplar. A segunda área, composta por chapas de metal que revestiam a parede de maior extensão do ambiente, tinha a função de capturar o olhar do espectador e the proporcionar a contemplação de vários planos de "cor/luz verdemetálica" (sic) ${ }^{16}$ quase hipnóticos, provenientes da aplicação de uma tinta especialmente fabricada para a obtenção desse efeito.

Como superfície plana, "Bico de Diamante" aludia à pintura tradicional ilusionista, ao "tableau" e este, por sua vez, à paisagem, conduzindo o espectador à uma experiência puramente visual que pretendia colocar em

\footnotetext{
${ }^{15}$ Exposição idealizada por Tadeu CHIARELl com a participação de Artur Lescher, Iran do Espírito Santo e Ana Maria Tavares. Inicialmente "Bico de Diamante" teria o título de "Paisagem" (o mesmo dado à obra de menor porte que deu origem à instalação "Bico de Diamante"), e seria composto a partir de um único painel de chapa metalizada verde. Finalmente foi necessário optar por uma superfície modulada para viabilizar a pintura, o transporte e a montagem. Utilizou-se um tipo específico de corte e dobradura de chapa $(82,0 \times 82,0 \times 0,3 \mathrm{~cm})$, comum na montagem de portões industriais, chamada Bico de Diamante, que permite maior estruturação das chapas finas de metal para a construção de portões de grande escala. A curiosa relação entre Bico de Diamante e o pigmento metalizado — glitter utilizado para a confecção da tinta, determinou o título final da obra.
}

${ }^{16}$ Expressão usada por Tadeu CHIARELL no catálogo da exposição individual realizada em 1990, no Gabinete de Arte Raquel ArnaUd, São Paulo, SP. 
suspensão a sua experiência do espaço-tempo real. A noção de paisagem advinha principalmente da articulação dos vários elementos do trabalho e, mais especificamente, do grande painel pintado na cor verde-azul, que banhava todo o espaço, produzindo um contraste complementar alaranjado e proporcionando uma atmosfera incomum ao ambiente.

Intermediando essas duas áreas, a do "beiral" preto e a do painel verde-azul, duas colunas brancas (parte da arquitetura da sala) assumiam, no contexto da obra, a função de estabelecer o ponto de fuga e reposicionar frontalmente o observador em relação ao plano da

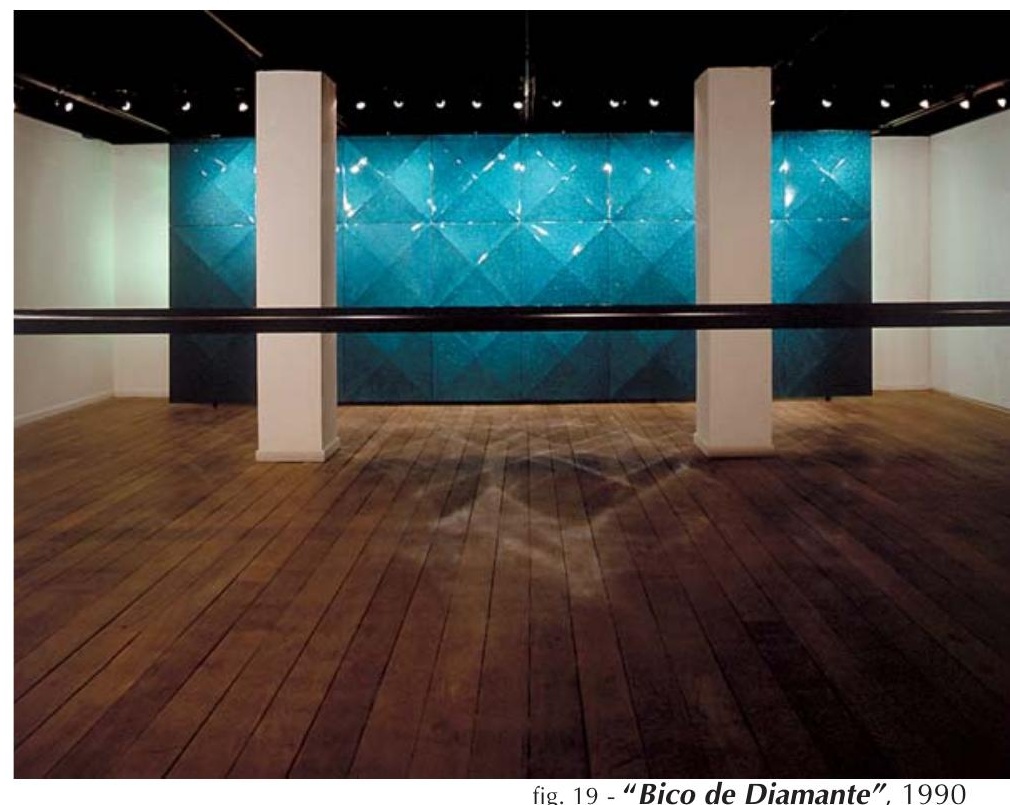
pintura/paisagem criada. Assim como o "beiral" instalado a alguns metros de distância das colunas, essas serviam para reorientar o acesso do olhar em relação ao campo luminoso verde-azul e se configuravam como uma moldura ampliada para essa "paisagem". Neste arranjo, onde "beiral" e colunas são reconhecidos primeiramente como estruturas que constituem o espaço arquitetônico, o visitante não hesita e busca o apoio para o corpo, já então rendido à fruição do espaço de cor-luz. Pressupõe-se que tanto o "beiral", como os para-peitos e uma série de outros elementos próprios da arquitetura, não implicam qualquer tipo de instrução de uso para que a interação seja estabelecida, pois já fazem parte do repertório do cotidiano do espectador. Estando o "beiral" fixado no piso da sala, de maneira a integrar-se completamente à arquitetura, restaria ao visitante somente duvidar se tais estruturas pertencem à obra ou à arquitetura, uma característica que o trabalho iria assumir deste momento em diante.

Olhando em retrospecto, este trabalho parece conter vários níveis de relações. A mais paradoxal delas reside no fato de se pretender, com esta articulação, que a obra contenha dois tempos e dois lugares distintos, que simultaneamente 
se opõem e se superpõem: o do observador e o da "arte". Atribuo ao elemento tridimensional, neste caso o "beiral" preto, a função específica de garantir ao observador o conforto necessário para que a experiência de contemplação da "arte" seja ilimitada. Crio impedimentos (o "beiral" e as colunas) para que o momento da experiência de contemplação seja retardado e a distância entre o universo real do observador e o universo metafórico da "obra" esteja claramente demarcado. Faço uma distinção entre o tempo da ação do observador (caminhar pela sala até se dirigir ao "beiral") como "anterior à arte" e o tempo da contemplação (apoiado no "beiral") como o "da própria arte". Porém este momento da ação é rapidamente dissolvido na experiência de contemplação e o observador, que se coloca imóvel diante daquilo que contempla, não é mais capaz de vivenciar o tempo "anterior à arte", pois é inteiramente absorvido no domínio do tempo "da própria arte". Nessa altura o beiral já perdeu toda a substância e só recuperará sua condição no instante em que o observador, já afastado, for capaz de ver "Bico de Diamante" em sua totalidade. ${ }^{17}$

\footnotetext{
${ }^{17}$ Cabe ressaltar aqui o papel importante que o trabalho do artista americano Robert Irwin (1928) teve, desde os anos 80, para a minha produção. Pintor expressionista abstrato até 1964, passou a se dedicar às investigações de uma "arte sem artifícios", na qual as relações entre espaço, luz e a percepção do observador são elementos constituintes de cada trabalho proposto. Para Irwin, o que mais interessava na obra era sua "presença" e não a autonomia da imagem ou do objeto.
} 


\subsection{A eSCUltura COMO APARELHO PARA O CAMPO DO CORPO E ARMADILHA para o olhar: "Alguns Pássaros (Those in Flight)", 1991}

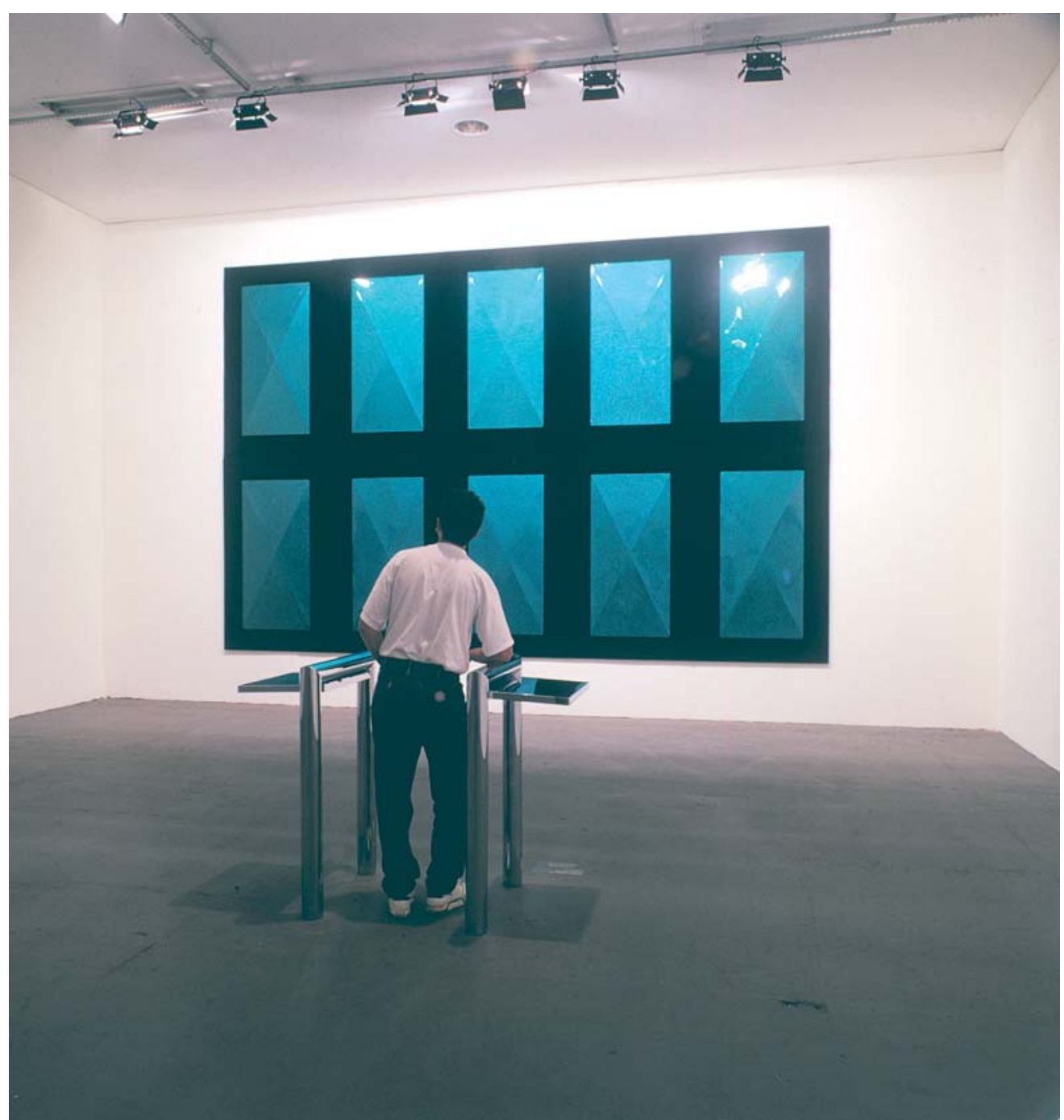

fig. 20 - "Alguns Pássaros (Those in Flight)" e "Tapete", 1991

"Alguns Pássaros (Those in Flight)" tratou de introduzir, de forma mais definitiva, o caráter da obra como um lugar para o observador, cuja função primeira seria interromper a realidade contínua de seu espaço-tempo. Na medida em que definia um espaço para a contemplação no interior da própria obra, ampliava os objetivos almejados com a introdução dos "beirais". Nesse sentido, o trabalho poderia ser entendido como um mirante, lugar que propicia a experiência distanciada da realidade ou mesmo um aparelho de transporte para outro espaço-tempo. 
"Alguns Pássaros (Those in Flight)" foi projetado tendo em vista a medida exata do corpo; sugere que o espectador ocupe este lugar. No título da obra, alguns é pronome indefinido, plural que significa mais de um, diversos, vários (entre maior número $)^{18}$ e refere-se àqueles que optarem por participar do trabalho; pássaros, ou a palavra em inglês flight (vôo), sugere a idéia de uma situação transitória, ou seja, a experiência do olhar atingindo outras paragens. No entanto, a sugestão de deslocamento, que se efetiva apenas virtualmente, é paradoxal: o espectador deve ser capturado pela escultura por meio de seus atributos hipnóticos. A superfície cromada dessa escultura absorve e reflete o seu entorno e as duas bandejas acopladas nas laterais da obra funcionam como espelhos que capturam o espectador ao refletir sua imagem. A passagem de um revestimento preto-fosco (característico das esculturas até então) para uma superfície cromada, foi a opção por uma dissolução da obra no seu entorno bem como o rebaixamento de sua presença como desenho expressivo, a fim de privilegiar outros conteúdos.

A noção da obra como armadilha para o olhar e aparelho para o campo do corpo surge aqui, pela primeira vez. Com inspiração nos "beirais", o arranjo dessas estruturas verticais fixadas no chão para apoiar o corpo tinha por objetivo afirmar a obra como um lugar protegido, para uma experiência que só poderia ser vivenciada através do corpo capturado e do olhar

Aproximar a obra às características do objeto utilitário, bem como introduzir materiais e técnicas análogas àquelas usadas para o apoio dos usuários de espaços públicos, foi fundamental para o surgimento das reflexões que, a partir de "Alog"unspađsássámnãa dófinòr lugar mas também o sujeito a quem a obra se refere, inaugurando-se assim uma série de novas considerações e significados para a produção que se seguiu.

\footnotetext{
${ }^{18}$ Ferreira, Aurélio Buarque de Holanda. Novo Dicionário Aurélio da Língua Portuguesa. Rio de Janeiro: Nova Fronteira, 1986.
} 
Armadilhas para os Sentidos: A EXPERIÊNCIA NO

ESPAÇO-TEMPO DA ARTE -

ESTRUTURAS, APARELHOS E O

SITE-SPECIFIC DESLOCADO

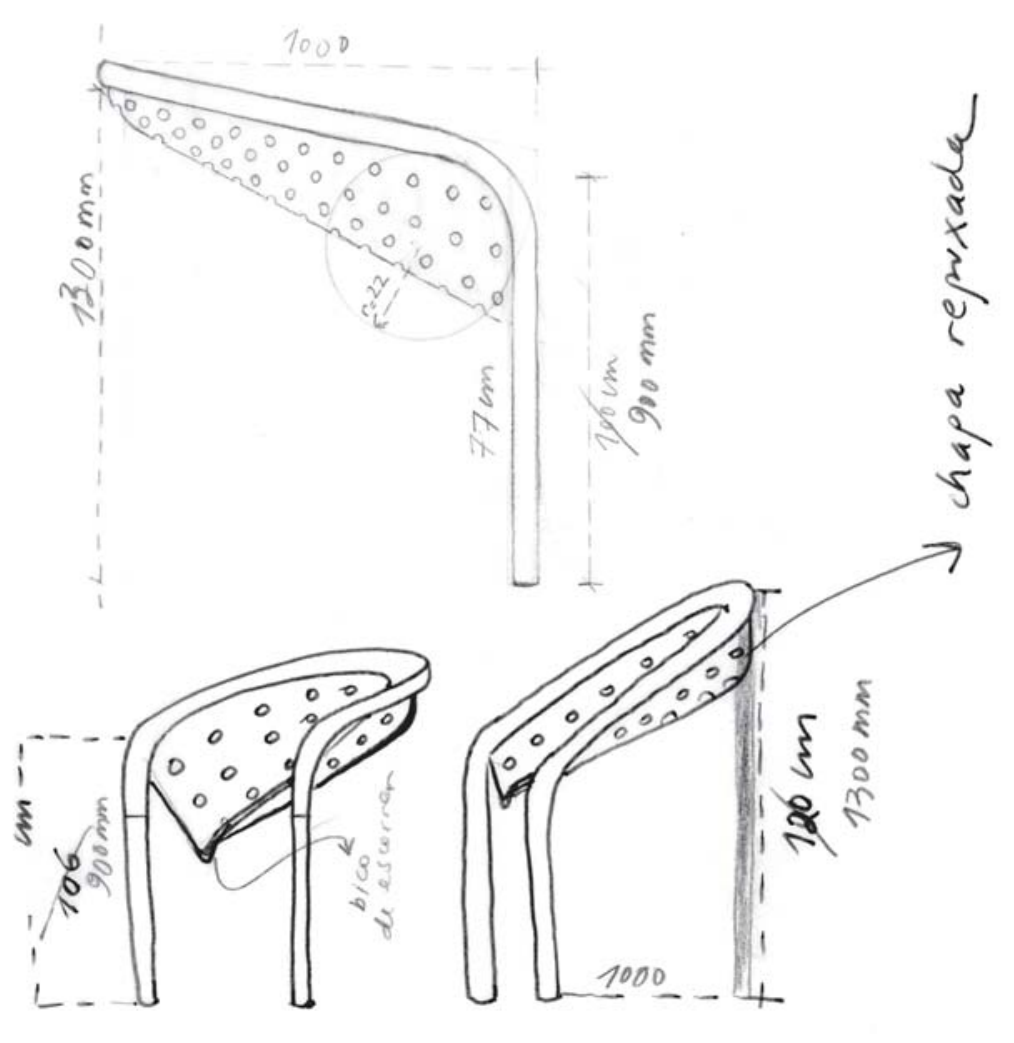


Nas séries da tese, a noção da obra como armadilha para o olhar, proposta inicialmente, ampliou-se para uma proposição mais complexa, a de armadilha para os sentidos. Privilegiar os sentidos e não apenas o olhar significou deixar de considerar a obra somente como um lugar para a contemplação daquilo que se apresentava fora dela (como no caso de "Alguns Pássaros" em sua primeira apresentação ${ }^{19}$ ou de "Bico de Diamantes") para propor uma relação sinestésica do espectador com a obra. Esta passagem ocorre a partir da introdução de novos recursos tais como a criação de áudios e o emprego de espelhos. Esse será um dos assuntos abordados neste capítulo.

Uma outra mudança conceitual de que este capítulo irá tratar ocorre a partir da incorporação dos espaços de passagem da vida contemporânea como referência para a produção. "Serpentinata" e "Belmont Station" bem como o conjunto de obras da exposição "Rotatórias" em 1996, são os primeiros exemplos desse novo direcionamento do trabalho, que possibilitou, posteriormente, a realização de dois conjuntos distintos de esculturas: as estruturas e as aparelhos.

Juntos, as estruturas e os aparelhos irão propor a experiência da obra como uma ação crítica. A alusão aos espaços urbanos através da apropriação e do deslocamento de elementos ou de situações que remetam a esse contexto, possibilitou estabelecer um vínculo estreito com o repertório imediato do espectador. Porém, esse deslocamento para dentro do espaço institucionalizado da arte tratou de transformar uma experiência antes corriqueira —a do "usuário" dos espaços públicos da cidade- em uma outra, de caráter pertubador. Assim desorganizam-se as referências do sujeito na tentativa de produzir uma suspensão espaço-temporal e uma dilação do momento de fruição da arte. Em conseqüência, foi possível formular o site-specific deslocado, que tem o objetivo

\footnotetext{
${ }^{19}$ Refiro-me aqui à situação proposta por ocasião da XXI Bienal Internacional de São Paulo em 1993, onde "Alguns Pássaros" foi exposta pela primeira vez. Neste contexto, pretendia-se privilegiar o uso da obra como um mirante para a contemplação daquilo que se encontra fora e distante dela, nesse caso, os "Tapetes".
} 
de capturar o sujeito, num jogo onde, como veremos, arte e arquitetura se deslocam mutuamente para desestabilizar as noções que poderiam tradicionalmente definir a escultura, a relação entre espectador e obra, e a própria arquitetura que Ihe serve de suporte.

\subsection{A escultura como estrutura de suporte para um corpo em trÂNSito: O CONflito do SUJeito — "Serpentinata", "Belmont StATION" E "Rotatórias"}

O termo estrutura foi escolhido a partir da observação do mobiliário urbano para conotar um tipo de elemento tridimensional cuja função é apoiar o corpo em situação de deslocamento. Geralmente confeccionadas a partir de barras tubulares de alumínio ou aço inox, essas estruturas são fixadas na arquitetura dos espaços públicos ou no espaço interno dos meios de transporte, tais como metrôs ou ônibus, e seu design é determinado por sua função —a saber: garantir segurança e conforto durante o deslocamento espaço-temporal. Nesta pesquisa elas pressupõem uma relação individualizada com o usuário e, uma vez inseridas no contexto da arte, as estruturas ambiguamente aludem também a uma possível experiência de vertigem.

Pensada como uma estrutura que remete aos corrimãos, a obra "Serpentinata" de 1995 poderia ser considerada como um momento de transição, pois apesar de avançar os conceitos introduzidos em "Alguns Pássaros", caracteriza-se pelos atributos originados no desenho ou, mais especificamente, no desenvolvimento de um gesto no espaço ${ }^{20}$.

Dois aspectos importantes estão presentes em "Serpentinata". O primeiro deles é a constituição da obra como um corredor para a passagem, transformando o sujeito em passageiro e participador que é convidado a atravessar a obra.

${ }^{20}$ Poderíamos fazer aqui um paralelo desta obra com a série "Chicotes" (1989-93) que também pretendia se caracterizar como desenho no espaço. 

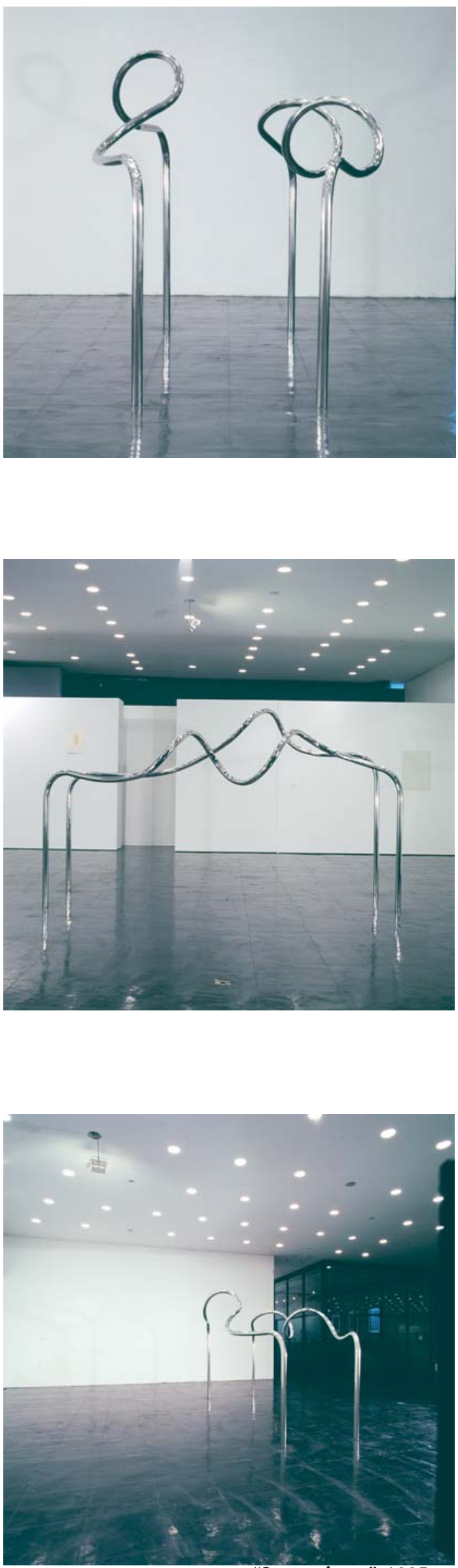

fig. 21 a 23 - "Serpentinata", 1995 
O segundo consiste na opção pelo uso do aço inox, implicando a manipulação e o domínio de uma nova técnica, bem como a incorporação dos significados provenientes desse material. Dentre todos os metais, o inox é o menos suscetível à corrosão devido à presença de cromo em sua composição. Em contato com o oxigênio do ar, o cromo forma uma camada extremamente fina, não porosa, contínua, estável e resistente que protege esse metal da contaminação do meio ambiente. Por possuir tais atributos é altamente indicado para a indústria alimentícia e hospitalar pois além de não desprender suas partículas, não contamina nem se deixa contaminar. Portanto, poderíamos concluir que é um material "indiferente" e a indiferença seria, do ponto de vista das relações, uma curiosa característica compartida entre espaços públicos de passagem e seus usuários, um dado de extrema importância na concepção dos trabalhos aqui expostos.

Pensada a partir desses pressupostos, "Belmont Station" tem como referência os bancos de metrô e o objetivo de definir um espaço interno para o descanso de um visitante/passageiro. A obra possui uma altura correspondente a dos corrimãos e seu comprimento determina um pequeno espaço/corredor. Ao contrário de "Serpentinata", articula os elementos apropriados do mobiliário urbano excluindo qualquer possibilidade de redefinição expressiva de suas partes. Uma vez reorganizados e inseridos no contexto da arte esses elementos, já então constituídos como obra, configuram um "meta-utilitário" cuja função não se define objetivamente. Nesse processo de deslocamento de contexto e de função é que se instaurará a "dúvida" ou o que escolhi definir como o "conflito do sujeito" e que passou a nortear a articulação conceitual proposta na exposição "Rotatórias" de 1996.

A escolha seletiva de elementos e situações próprias dos espaços urbanos de passagem implicou uma observação atenta do comportamento coletivo. No trato com tais espaços, os usuários, fechados em seus universos pessoais, executam com eficiência os comandos que são regulados pela arquitetura e pelo design 
e incorporados pelo hábito. Esses usuários são especialistas ${ }^{21}$ que transformam seus gestos individuais em fluxo coletivo caracterizado pela "distração", pela "anestesia" e pela "indiferença". Juntos, esses três conceitos irão se interrelacionar, caracterizando a condição do usuário desses espaços públicos.

Vale observar que a experiência do sujeito contemporâneo que transita pela cidade difere daquela do flâneur de Baudelaire, pois este, de plena posse de sua individualidade, mantém ativamente o seu contato com o mundo externo, enquanto o sujeito contemporâneo figura nos espaços públicos desconectado. Como observa Walter Benjamin, "no flâneur, o desejo de ver festeja o seu triunfo. Ele pode concentrar-se na observação — disso resulta o detetive amador; pode se estagnar na estupefação — nesse caso o flâneur se torna um basbaque" 22 .

A "distração" não é entendida aqui como uma desatenção ou uma ação descuidada. Ela deve ser vista como um alheamento ou um desvio, um estado de espírito que possibilita a abstração do contexto e, conseqüentemente, um deslocamento mental no espaço e no tempo. Mas a "distração" não congela a ação competente e o usuário permanece potencialmente ativo.

A "anestesia" e a "indiferença" seriam manifestações dos sentidos que remetem à capacidade dos indivíduos de lançar mão de recursos próprios para se resguardar das condições ameaçadoras da vida na atualidade. Exposto ao contexto urbano, o indivíduo está em constante situação de alerta devido à sua consciência de risco: risco de ser irreversivelmente seduzido pela mídia e pelo consumo, risco advindo da crescente violência urbana, risco da perda da individualidade, ou do individualismo exacerbado de nossos tempos, risco da

\footnotetext{
${ }^{21}$ O termo especialista refere-se aqui ao fato de que o usuário domina com precisão e competência as práticas e o funcionamento dos equipamentos disponíveis no espaço público.

22 Benjamin, Walter "Paris do Segundo Império" in Charles Baudelaire: Um Lírico no Auge do Capitalismo. São Paulo: Brasiliense, 1989, p. 69. Em nota de rodapé o autor alerta, citando Victor Fournel, para a diferença entre o flâneur e o basbaque: a individualidade no basbaque desaparece — "foi absorvida pelo mundo exterior...; este o inebria até o esquecimento de si mesmo. Sob a influência do espetáculo que se oferece a ele, o basbaque se torna um ser impessoal; já não é um ser humano; é o público, é a multidão". Apesar das semelhanças dessa descrição do basbaque com o sujeito contemporâneo, as diferenças prevalecem: assim como Narciso, o basbaque se perde de si mesmo na contemplação, enquanto o sujeito contemporâneo nada contempla fora de si mesmo, e permanece indiferente ao mundo circundante.
} 
contaminação, etc. Somos todos indivíduos frágeis e essa fragilidade nos transforma em seres cautelosos e ágeis para calcular e prever as conseqüências futuras de nossas ações do presente ${ }^{23}$.

A “anestesia" e a "indiferença" poderiam ser também vistas a partir do que Keneth Gergen sugere como definição do indivíduo contemporâneo: o "saturated self" ou o "populated self"24. "Saturar" e "povoar" pressupõem um excesso que resulta no esgotamento físico e emocional do indivíduo frente às condições sociais e ao bombardeamento das tecnologias da informação. Sem perder os sentidos, porém insensível ao próximo e ao outro, o indivíduo contemporâneo faz da "indiferença" e da "anestesia" o salvo-conduto que possibilita o tráfego por entre as múltiplas ações que regem os espaços das grandes cidades.

É nesse contexto que o design se potencializa. Concebidos como objetos funcionais estruturados segundo uma lógica utilitária e mais ainda, que suscita o uso, esses objetos de design são transmissores de "certezas" pois colaboram para revelar os objetivos de um dado contexto arquitetônico e afirmar a competência de seus usuários. Portanto, o "conflito do sujeito" somente se efetivará enquanto for possível estabelecer uma relação dialética entre a "certeza" (do design) e a "dúvida" (da arte) no contexto das experiências do sujeito.

A interdependência entre a "dúvida" e a "certeza" é exposta de forma clara e sintética por Vilém FLUSSER e podemos aqui considerá-la:

A dúvida é um estado de espírito polivalente. Pode significar o fim de uma fé, ou pode significar o começo de uma outra. Pode ainda, se levada ao extremo, ser vista como "ceticismo", isto é, como uma espécie de fé invertida. Em dose excessiva paralisa toda atividade mental. A dúvida, como exercício intelectual, proporciona um dos poucos prazeres puros, mas como uma experiência moral ela é uma tortura.

\footnotetext{
${ }^{23}$ Para uma abordagem mais aprofundada a respeito da relação entre corpo e risco ver VAZ, Paulo. "O Corpopropriedade" in Neto Fausto e M. J., Pinto. Mídia e Sociedade: Rio de Janeiro: Diadorim, 1997.

${ }^{24}$ GerGen J., Kenneth. The Saturated Self: Dilemmas of Identity in Contemporary Life. Estados Unidos: Basic Books, 1991, pp. 48-80.
} 
A dúvida, aliada à curiosidade, é o berço da pesquisa, portanto de todo conhecimento sistemático. Em estado distilado, no entanto, mata toda curiosidade e é o fim de todo o conhecimento.

O ponto de partida da dúvida é sempre uma fé. Uma fé (uma "certeza") é o estado de espírito anterior à dúvida. Com efeito, a fé é o estado primordial do espírito. O espírito "ingênuo" e "inocente" crê. Ele tem "boa fé". A dúvida acaba com a ingenuidade e inocência do espírito e, embora possa produzir uma fé nova e melhor, essa não mais será "boa". A ingenuidade e inocência do espírito se dissolvem no ácido corrosivo da dúvida. O clima de autenticidade se perde irrevogavelmente. O processo é irreversível. As tentativas dos espíritos corroídos pela dúvida de reconquistar a autenticidade, a fé original, não passam de nostalgias frustradas. São tentativas de reconquistar o paraíso. As "certezas" originais postas em dúvida nunca mais serão certezas autênticas. A dúvida metodicamente aplicada produzirá, possivelmente, novas certezas, mais refinadas e sofisticadas, mas estas novas certezas nunca serão autênticas. Conservarão sempre a marca da dúvida que thes serviu de parteira. ${ }^{25}$

O objetivo da exposição "Rotatórias" formada por seis esculturas — "Corrimão", "Cabine", "Guarda-Corpo", "Escorredor", "Coluna com duas alças" e "Rotatória" — era ampliar a experiência do "conflito do sujeito" e criar uma situação espacial que estimulasse o percurso do visitante pelas duas salas da mostra.

Composta de esculturas em aço inox (com detalhes em couro e teflon), essas obras pareciam ter um denominador comum: uma clara relação com os equipamentos do espaço urbano. Porém, observando mais atentamente, o visitante perceberia a necessidade de adequar sua experiência aos pressupostos de dois conjuntos distintos de objetos.

O primeiro deles, formado por "Corrimão", "Cabine", "Guarda-Corpo" e "Coluna com duas alças" estava claramente relacionado ao que

\footnotetext{
${ }^{25}$ FluSSER, Vilém. A Dúvida. Rio de Janeiro: Relume Dumará, 1999, pp. 17-18.
}
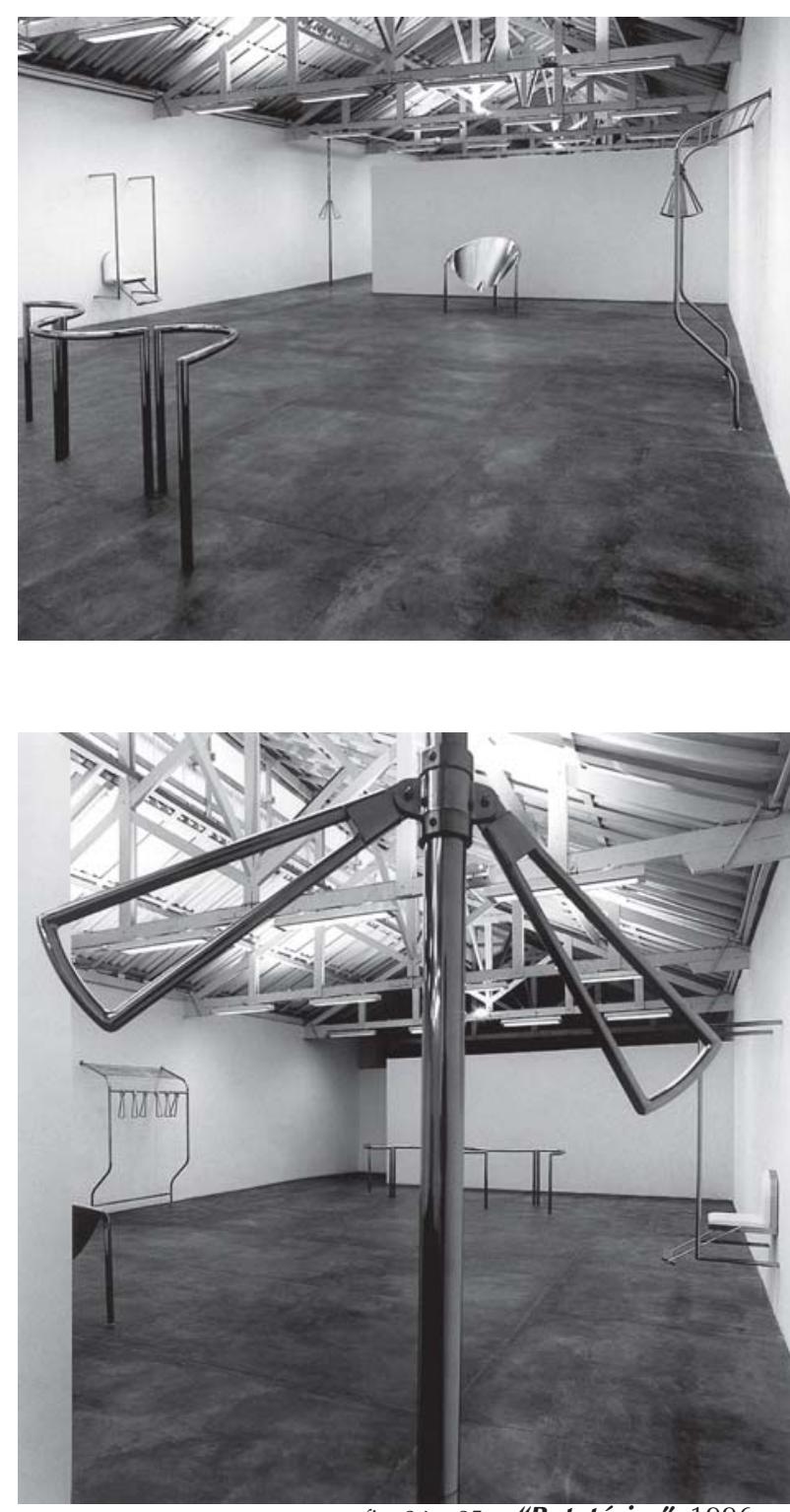
passei então a denominar estruturas de suporte para o corpo, inspirados no mobiliário urbano. Aqui, o apelo para o uso incorporava recursos como o rigor ergonométrico e o trato cuidadoso dos materiais e das técnicas industriais empregadas. A "distração" ou o hábito poderiam conduzir ao uso imediato em obras tais como "Corrimão" ou "Coluna com Alças". Porém, o contexto neutralizador desse espaço de arte, a galeria, gerava um estranho congelamento das funções desses objetos utilitários que, por fim, pareciam se apresentar como "meta-máquinas", "meta-passagens" ou "meta-apoios". Desta forma se instaurava a "dúvida" a respeito da condição desses objetos. Tendo sido removidos de seus supostos contextos de origem, o que caberia ao visitante, uma vez que os objetos pareciam ter sido destituídos de seus significados e funções originais?

Responder a tal questionamento implicava porém o entendimento das articulações conceituais presentes em duas outras obras, "Escorredor" e "Rotatória" que, ao contrário das outras, eram esculturas cuja natureza visava somente a fruição estética do todo. Em "Escorredor" a função é apenas aludida e parece inviabilizada pelas alterações de escala e, sobretudo, pela carga metafórica que revela em sua forma. Nesse sentido, poderia ser considerada como um "objeto incompetente", pois nega qualquer possibilidade de uso efetivo. Mesmo remetendo ao uso, "Escorredor" e "Rotatória" assumem os desígnios de uma escultura que privilegia e mantém a contemplação e a subjetividade como essência de sua relação com o público (característica recorrente na produção até 1991) para interromper abruptamente o apelo à ação proposto em outras obras. "Escorredor" e "Rotatória" parecem atuar na contramão dos conceitos tratados no primeiro conjunto de obras pois proporcionam um ruído na compreensão do todo e ampliam ainda mais o sentido do "conflito", colaborando para redefinir a experiência a partir de indagações a respeito da natureza e significado dos objetos.

Neste contexto, a obra "Guarda-Corpo" é ambivalente, pois além de conter características de uma estrutura para o apoio do corpo, pode ser entendida também como um aparelho que irá possibilitar o deslocamento do sujeito no espaço e no tempo. 


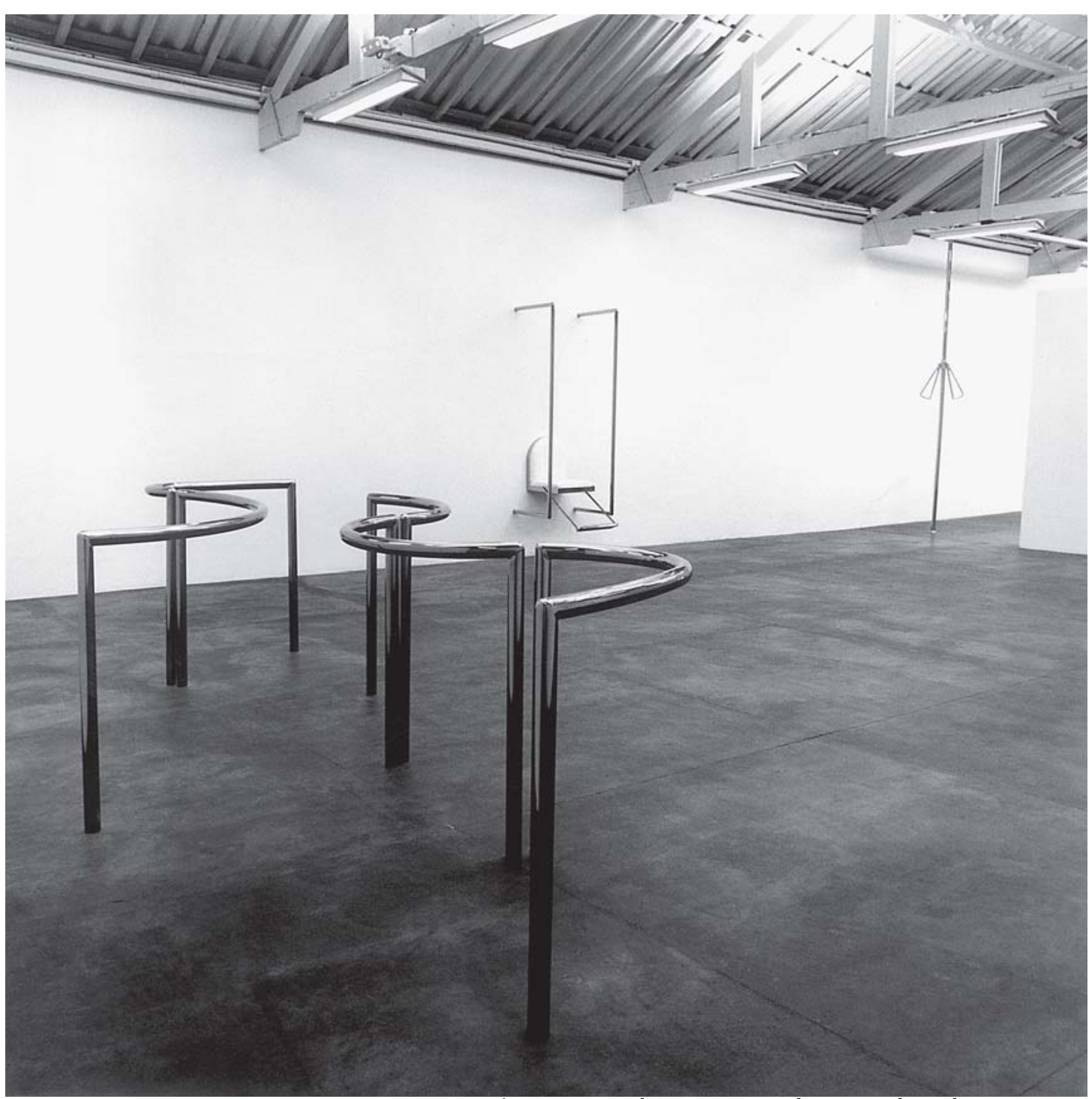

fig. 26 - "Corrimão", "Guarda-Corpo" e "Coluna com duas alças", 1996 
Ana Maria Tavares

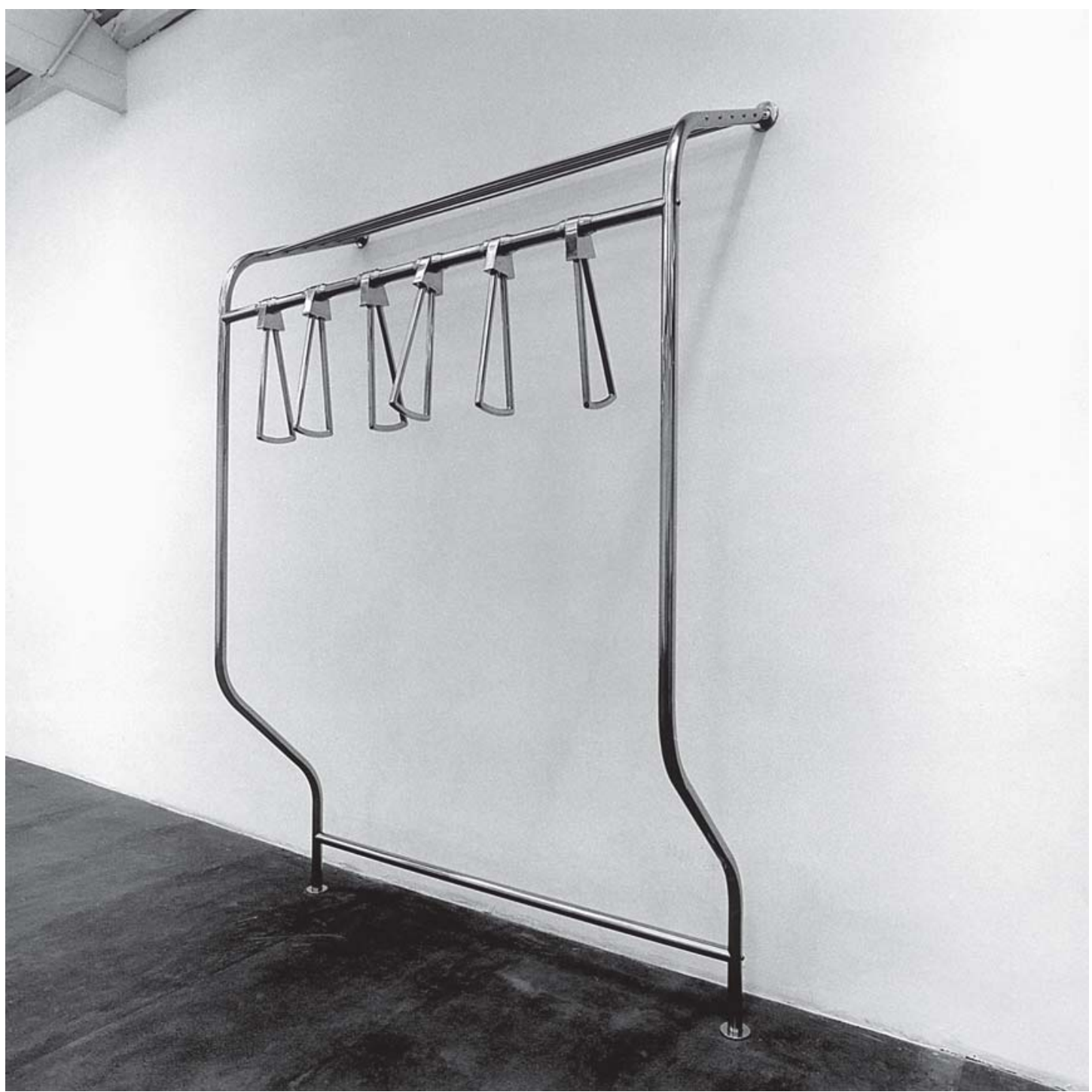

fig. 27 - “Cabine", 1996 

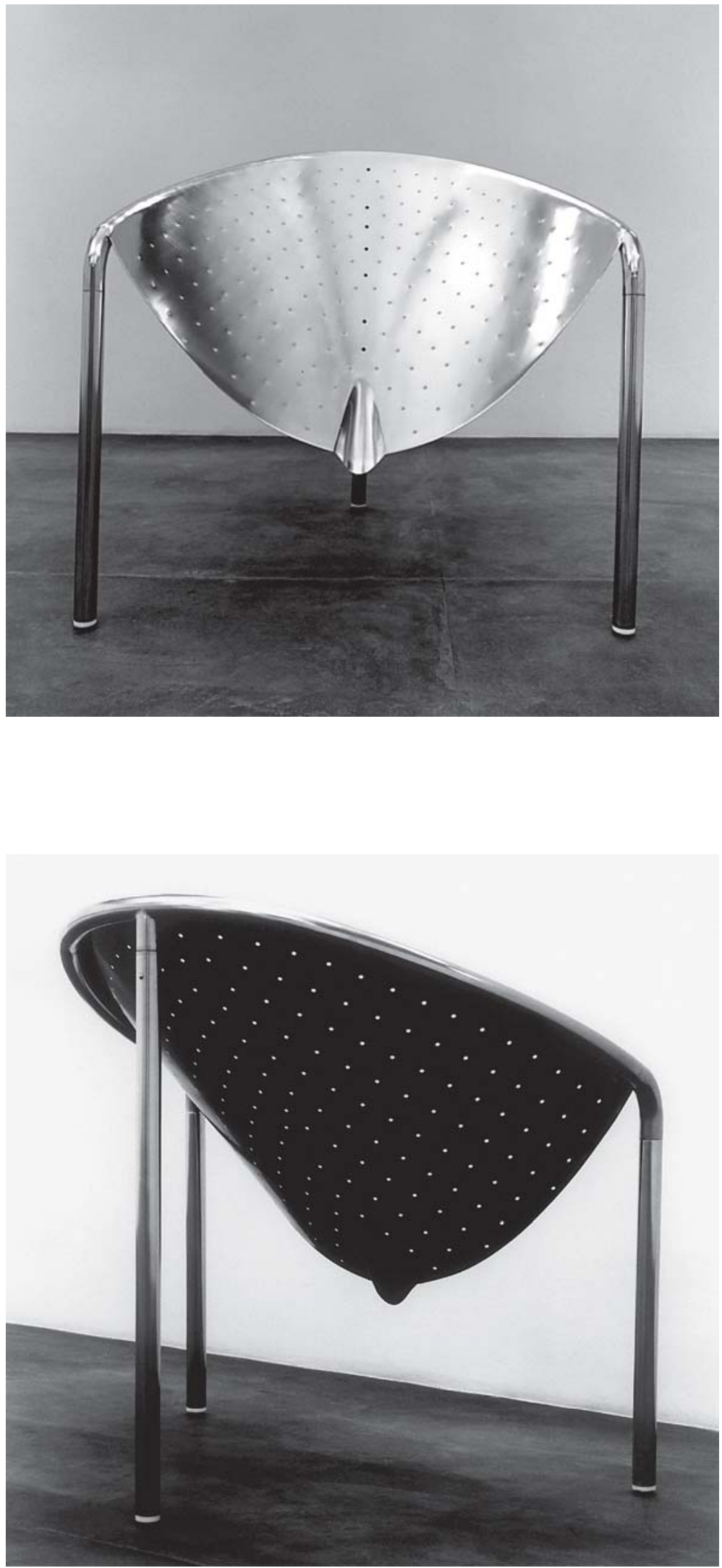

fig. 28 e 29 - "Escorredor", 1996 


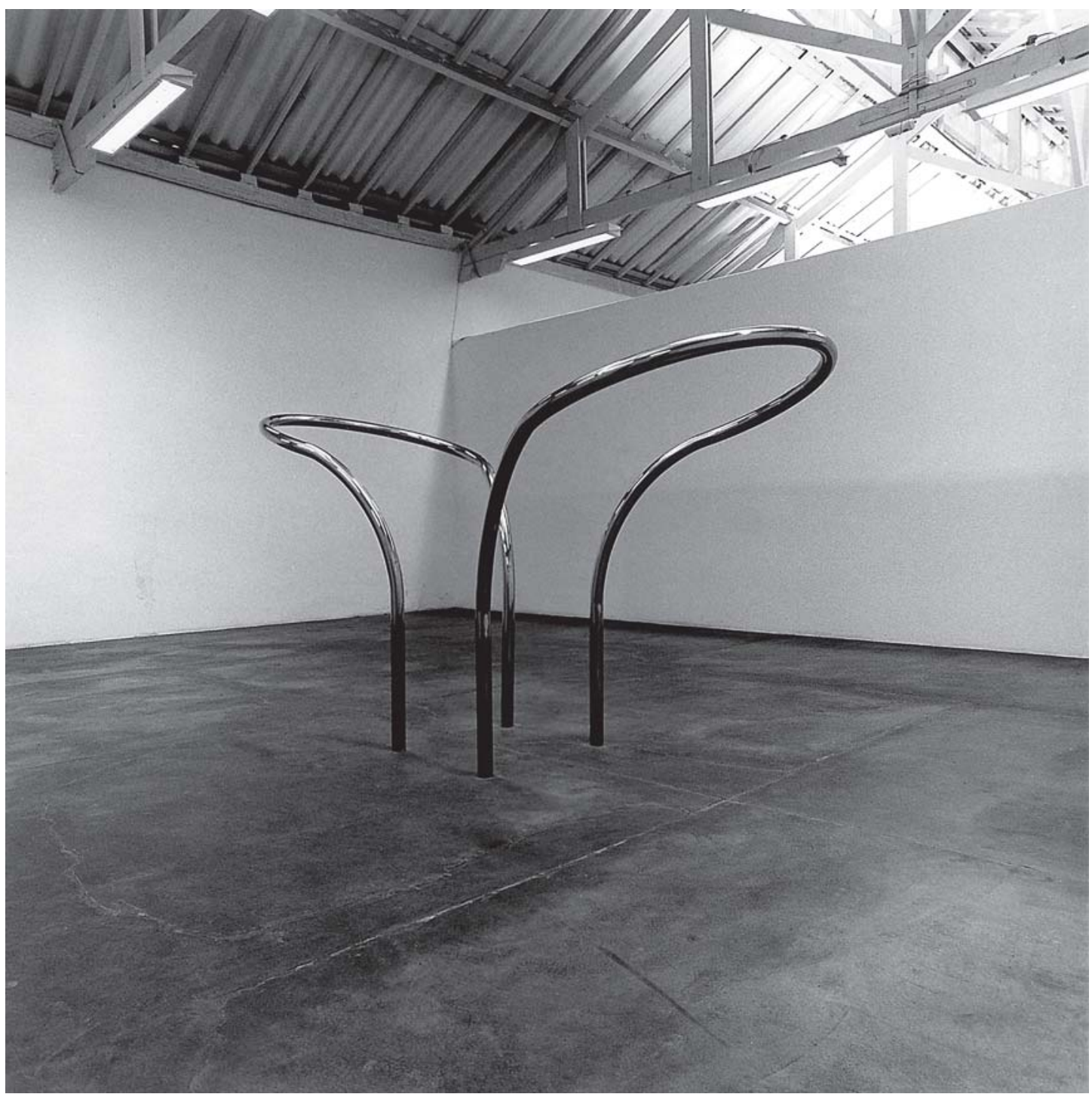

fig. 30 - "Rotatória", 1996 


\subsection{A escultura como aparelho para o campo do corpo - "Alguns Pássaros (Those in Flight)", "Guarda-Corpo", "Visita Guiada com Amigo J9. Para EDemar" e "Exit"}

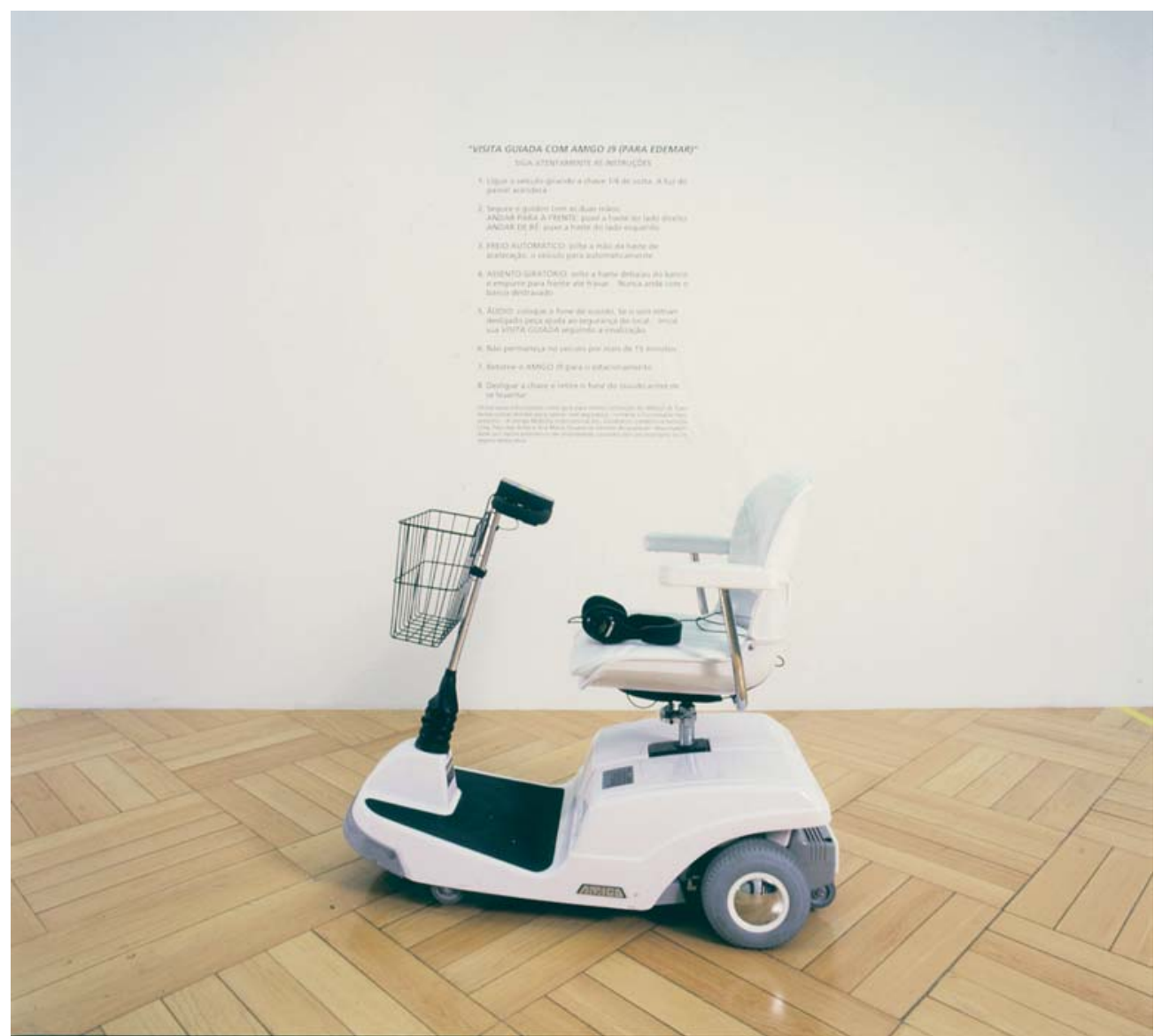

fig. 31 - "Visita Guiada com Amigo J9. Para Edemar", 1997

O termo aparelho é empregado aqui para caracterizar a escultura como um conjunto de "mecanismos"26 cuja finalidade específica seria funcionar como espécies de próteses $^{27}$ para o campo do corpo. O aparelho instituirá portanto um território de domínio do sujeito submetido ao espaço-tempo da obra. Trata-

${ }^{26}$ Refiro-me aqui às obras nas quais os processos de funcionamento determinam uma série de fases subordinadas e dependentes umas das outras ou àquelas em que cada etapa de interação é determinada por condições antecedentes invariáveis, conforme definição de aparelho no Novo Dicionário Aurélio da Língua Portuguesa. Rio de Janeiro: Nova Fronteira, 1986.

${ }^{27}$ Idem. A definição de prótese pressupõe a relação de dependência com o sujeito uma vez que sua função seria a de suprir uma falta, de "substituir artificialmente uma parte" ou "aumentar uma função natural". 
se, dessa forma, de uma prótese para o território de domínio do sujeito e não simplesmente uma prótese para o corpo. Assim definidos, os aparelhos têm, em sua essência, a característica de prolongar a experiência da obra e amplificar os sentidos, a fim de estimular a consciência crítica do sujeito submetido à experiência da arte. A arquitetura é o contexto apropriado para a constituição dos significados de um aparelho pois é na relação entre obra e espaço que se estabelecerão as premissas indispensáveis para a potencialização da experiência crítica.

Incrementar o potencial natural do homem através da invenção de objetos que Ihe sirvam como prolongamento do corpo é uma atividade característica da humanidade desde tempos remotos. Tal atividade está geralmente associada a uma idealização da capacidade intelectual e operante do homem.

Sigmund Freud, em O Mal Estar na Civilização, 1930, discorre a respeito da habilidade do ser humano de ampliar suas capacidades naturais definindo-o como um "deus protético": uma vez tendo acoplado todas as suas "extensões", torna-se um ser "magnificente":

Com todo instrumento o homem está aperfeiçoando seus próprios órgãos, quer sejam motores ou sensoriais, ou está ampliando os limites de seu funcionamento. A potência de motores [motor power] coloca forças gigantes à sua disposição, as quais, como seus músculos, ele pode empregar em qualquer direção; graças aos navios e aviões nem a água nem o ar pode impedir seus movimentos; através de óculos ele corrige os defeitos nas lentes de seus próprios olhos; através do telescópio ele enxerga a longa distância, e através do microscópio ele ultrapassa os limites da visibilidade determinados pela estrutura de sua retina. Com a máquina fotográfica ele criou um instrumento para fixar as efêmeras impressões visuais, tal como o disco de gramofone retém impressões igualmente fugazes; ambos são, no fundo, materializações do poder que ele possui de recordar, sua memória. Com a ajuda do telefone ele pode ouvir à distâncias que seriam consideradas inatingíveis mesmo nos contos de fadas. A escrita era em sua origem a voz de uma pessoa ausente; e a residência um substituto do útero materno, o primeiro alojamento, pelo qual, com toda probabilidade, o homem ainda anseia, e no qual ele estava seguro e sentia-se à vontade. O homem tem, por assim dizer, se transformado em um deus protético. Quando ele coloca todos os seus órgãos auxiliares ele é verdadeiramente magnificente; mas esses órgãos não se desenvolveram nele e às vezes ainda the causam muito trabalho ${ }^{28}$.

\footnotetext{
${ }^{28}$ Freud, Sigmund. Apud. Wigley, Mark "Prosthetic Theory: The Disciplining of Architecture" in Assemblage A Critical Journal of Architecture and Design Culture", vol 15, Agosto, 1991, p. 24. Todas as traduções das citações são de minha autoria.
} 
Assim como pensa FREUD a respeito da residência, para Le Corbusier, a arquitetura moderna seria também vista como extensão tecnológica do corpo, como prótese. Eis o que observa Mark Wigley a respeito desse arquiteto moderno:

Deslocada do artifício para o artificial, a arquitetura moderna tornou-se uma extensão tecnológica do corpo que não é nem natural nem cultural. A Arquitetura moderna é o espaço do artificial. Como Le Corbusier argumenta:

"Todos nós precisamos de meios para suplementar nossas capacidades naturais, visto que a natureza é indiferente, desumana (extra-humana), e inclemente; nascemos nus e com armadura insuficiente... O barril de Diógenes, já uma melhora notável em nossos órgãos naturais de proteção (nossa pele e couro cabeludo), nos deu a célula primordial da casa; arquivos e copy-letters corrigem as inadequações de nossa memória; guarda-roupas e aparadores são os 'containers' nos quais guardamos os membros auxiliares que nos protegem contra o frio ou calor, fome ou sede.... O que nos interessa é o sistema mecânico que nos rodeia, que nada mais é senão uma extensão de nossos membros; seus elementos, de fato, membros artificiais" $29^{29}$

\section{WigLey cita Le Corbusier novamente:}

Ferramentas são as extensões úteis dos braços e pernas dos homens. Essa definição pode ser estendida para abranger certos produtos da genialidade humana os quais também têm a intenção de secundar a pessoa como tal: a residência é um ferramenta, como também o são a estrada, a oficina, e assim por diante..$^{30}$

Nas referências citadas podemos verificar que uma das características do homem moderno, tal como apontadas por FREUd e Le CORBUSIER, parece ser sua capacidade de transformar a si próprio em um ser mais que perfeito, fazendo de suas próteses um meio para dominar e subordinar a natureza à sua própria existência. Essa seria uma visão positiva da prótese pois implica, em primeira instância, que as "extensões do corpo" servem para "equipar" o homem como um ser completo, "magnífico", um homem-máquina, aquele que irá idealizar um futuro promissor e ilimitado.

\footnotetext{
${ }^{29}$ WIGLEY, Mark. "Prosthetic Theory: The Disciplining of Architecture" in Assemblage A Critical Journal of Architecture and Design Culture", vol 15, Agosto, 1991, p. 7.

${ }^{30}$ Le Corbusier. Apud Wigley, Mark "Prosthetic Theory: The Disciplining of Architecture. in Assemblage A Critical Journal of Architecture and Design Culture" 15, Agosto, 1991, p. 24.
} 
Ao analisar o período que compreende os séculos XVIII a XX, Lúcia SANTAELLA ${ }^{31}$ aponta em $\underline{\mathrm{O} \text { Homem e as Máquinas }}{ }^{32}$ a distinção entre os utensílios, as ferramentas e as máquinas ${ }^{33}$ e faz um mapeamento da relação homem-máquina em três níveis essenciais: 1) o nível muscular-motor, 2) o nível sensório, 3) o nível cerebral. A partir dessa classificação define três tipos de máquinas, criadas pelo homem, que viriam alterar a imagem de si mesmo e sua relação com o mundo. O primeiro tipo seriam as "máquinas musculares" definidas como "servis" e "tarefeiras". Surgidas com a Revolução Industrial (ou revolução eletromecânica que transformava energia química em energia cinética), caracterizam-se pela possibilidade de substituir os movimentos musculares por outros, mecânicos, repetitivos e grosseiros, ampliando em velocidade e quantidade aquilo que poderia ser realizado pelo homem. O segundo tipo de máquina determinaria o surgimento do que a autora descreve como "máquinas sensórias", cuja característica fundamental é o fato de terem sido criadas a partir de estudos científicos precisos a respeito do funcionamento de, fundamentalmente, dois sentidos humanos: a visão e a audição. Por estarem intimamente ligadas ao que Santaella aponta como "especialização dos sentidos ou aparelhamentos da visão e da escuta humanas", essas máquinas são um prolongamento dos órgãos dos sentidos, são aparelhos capazes de

\footnotetext{
31 Na sua análise SANTAella mostra afinidade teórica com Edward T. Hall e McLuHAN. Basta ver que, em "Laws of Media", McLuhan cita Edward T. Hall que, já em 1959, descrevia os artefatos feitos pelo homem como extensões do corpo: "Hoje o homem desenvolveu extensões para praticamente tudo que ele costumava fazer com seu corpo. A evolução de armas começa com o dente e o punho e termina com a bomba atômica. Roupas e casas são extensões dos mecanismos biológicos de controle de temperatura do homem. Móveis tomam o lugar de ficar de cócoras e sentar no chão. Ferramentas elétricas, óculos, TV, telefones, e livros que carregam a voz através tanto do tempo quanto do espaço são exemplos de extensões materiais. Dinheiro é uma maneira de estender e armazenar trabalho. Nossa rede de transporte agora fazem o que estávamos acostumados a fazer com nossos pés e costas. De fato, todas as coisas materiais feitas pelo homem podem ser tratadas como extensões daquilo que o homem uma vez fez com seu corpo ou alguma parte especializada do seu corpo". (HaLL, Edward T. Apud McLuHAN, Marshall and Eric. "Laws of Media" in Laws of Media: The New Science. Toronto: University of Toronto Press, 1988, p. 94.)

32 Santaella, Lúcia. "O Homem e as Máquinas" in Domingues, Diana. Arte no Século XXI: A Humanização das Tecnologias. São Paulo: UNESP, 1997, pp. 33-44.

${ }^{33}$ Idem, p. 33. De acordo com SANTAELLA, os utensílios são objetos criados especificamente para o uso e as ferramentas são artefatos inventados para cumprir uma determinada tarefa. Assim sendo, as ferramentas seriam então "extensões ou prolongamento das habilidades, na maior parte das vezes manuais, o que explica porque as ferramentas são artefatos do tipo engenhoso". A adaptação ao corpo é uma característica fundamental das ferramentas, na medida em que têm a finalidade de ampliar o "movimento físico-muscular humano". Desta forma, as máquinas estariam diretamente relacionadas às ferramentas na medida em que são criadas com o mesmo objetivo, porém suplantandoas pois apresentam ainda "um nível de autonomia no seu funcionamento".
} 
simular o funcionamento humano e captar registros do mundo, reproduzindo-o em signos tais como as imagens e os sons. A máquina fotográfica ou o telefone poderiam ser exemplos de tais aparelhos. O terceiro e último tipo seria constituído pelas "máquinas cerebrais", que têm no computador seu melhor representante. Conforme SANTAElla, a investigação de processos humanos internos culminou na substituição da palavra máquina "pelas conexões mais fluidas das interfaces, através das quais os computadores vão crescentemente se potencializando para novas interações". Finalmente, a autora conclui que, "se as máquinas musculares amplificam a força e o movimento físico humano e as máquinas sensórias dilatam o poder dos sentidos, as máquinas cerebrais amplificam as habilidades mentais, notadamente as processadoras e as da memória".

Pensar as esculturas-aparelhos como "máquinas sensórias que dilatam o poder dos sentidos" significa equipar o sujeito com os meios adequados que o possibilitem "produzir e reproduzir entidades inauditas que viriam provocar modificações profundas na própria paisagem do mundo". Poderíamos aqui considerar não só as "entidades inauditas", referidas por SANTAELLA, mas também aquelas jamais vistas por um olho não equipado. Esses aparelhos, além de produzirem modificações na paisagem do mundo (da arte), provocariam também modificações na percepção que o indivíduo tem de si mesmo quando submetido ao espaço-tempo da arte.

Tais como as máquinas especializadas, os aparelhos "Alguns Pássaros (Those in Flight)", "Guarda-Corpo", "Visita Guiada com Amigo J9. Para Edemar" e "Exit", funcionam a partir da interação e do uso operado por um sujeito participador $^{34}$ e ativo, nessa pesquisa denominado usuário. Proporcionar a participação implica em instituir uma parceria entre autor e fruidor e,

\footnotetext{
${ }^{34}$ Apresentadas sob várias formas e através de inúmeros meios, a ênfase na participação do espectador abrange grande parte da produção artística do século XX. A idéia de atribuir ao espectador essa qualidade nos remete à produção artística das primeiras décadas desse século e pode ser claramente notada nas preocupações de $E I$ Lissitzky e seus contemporâneos russos. Influenciados pelo movimento das novas máquinas da indústria e da ação característica do teatro, buscavam compelir o espectador à ação: "Havia comparações freqüentes da nova arte com
} 
consequentemente, promover uma constante renovação da obra, noções estas que já são esboçaçadas na produção de escultores desde o final do século XIX e amplamente exploradas por artistas até o momento atual ${ }^{35}$. Porém, é a partir das atitudes implicadas nas obras e nos textos de Marcel Duchamp que a noção de transformar a experiência da arte em ação participativa se reformula radicalmente, estabelecendo novos parâmetros para a relação entre o artista, obra e espectador.

Para Marcel Duchamp o ato criativo não cabe apenas ao artista, "o espectador traz a obra para o mundo externo ao decifrar e interpretar suas qualidades interiores, adicionando assim sua contribuição ao ato criativo ${ }^{\prime \prime 36}$. Ao esvaziar o objeto de seus significados, criando o que definiu como objetos indiferentes, Duchamp desvia a atenção da obra (produto) e do artista (gênio) para a relação entre obra, artista e espectador. Juntos, esses três elementos passam a constituir o novo contexto no qual a experiência será transformada em ação crítica e consciente do próprio sistema que estrutura a arte. Esta seria então uma "net-art", conforme define Martin GrossmanN ${ }^{37}$, arte em que o significado da obra é determinado pela interrelação das partes que compõe o contexto e seu sistema.

o maquinário e com o teatro, os quais se caracterizavam pelo movimento e um sentido de drama. (...) Em toda volta Lissitsky se deparava com a visão de que a essência dos tempos se encarnava nos eventos. Ele revelava essa posição no seu desejo de criar um espectador apropriadamente ativo (...) mas com o desejo adicional de "controlar a ação do espectador e não deixá-las ao acaso". BIRNHOLz, Alan C. "El Lissitzky and the Spectator: From Passivity to Participation" in Barron, S. \& Tuchman, M. (org.) The Avant-Garde in Russia, 1919-1930: New perspectives. Cambridge, Massachusetts: The Mit Press, 1980, pp. 98.

${ }^{35}$ Dois exemplos relevantes, talvez os primeiros a demonstrarem o comprometimento com um espectador ativo, seriam as obras de Auguste Rodin e Merdado Rosso. Para esses artistas, a escultura deixa de revelar a articulação de um interior idealizado - anatomia, noções de proporção e equilíbrio, etc - cujo resultado deveria culminar em uma narrativa linear, um assunto ou tema que se completaria antes mesmo da experiência do espectador. Em Rodin, a escultura passa a se constituir como uma superfície ativa que resgata o espectador numa experiência cuja natureza atualiza a obra no momento mesmo de sua fruição. Ao invés de se definir como uma realidade autônoma e independente, a obra passa a gerar significados na medida em que o espectador a vivencia visualmente. Para uma análise aprofundada a respeito da transição dos significados da escultura do interior privado para o exterior público, que implica a participação do espectador no espaço-tempo da obra, ver Krauss, Rosalind. E. Opus cit.

${ }^{36}$ Duchamp, Marcel. "The creative Act"(1953) in Sanolllet \& Peterson. The Writings of Marcel Duchamp. Oxford: Da Capo,1973, p. 140.

${ }^{37}$ Grossmann, Martin. Item-3 Rio de Janeiro. Vol 3, fevereiro 1996, pp. 29-37. 
A obra denominada "Guarda-Corpo", que foi projetada para ser afixada na superfície branca da parede, reserva um assento para o visitante e tem como complemento duas barras de proteção instaladas ao alcance das mãos. Um pequeno suporte para o apoio dos pés, acoplado à parte inferior do assento, faz com que o visitante fique confortavelmente posicionado a uma altura de, aproximadamente, oitenta centímetros acima do nível do chão. Esse pequeno deslocamento parece ser o suficiente para nomear um espaço diferenciado de onde o visitante observa.

Além de provocar uma
experiência similar àquela que
KRauss, ao tratar a obra de
Giacometti, denomina como
uma "fenda na realidade
contínua do espaço"38, "Guarda-
Corpo" pretende transformar o
espectador em uma espécie de
usuário/analista e capacitá-lo a
reconhecer o "momento-arte" 39
ao qual está submetido. Como
um aparelho/prótese, "Guarda-
Corpo" cumpre a função de
amplificar a capacidade
perceptiva e mental de seu
usuário através da dilação da
experiência no interior da obra.

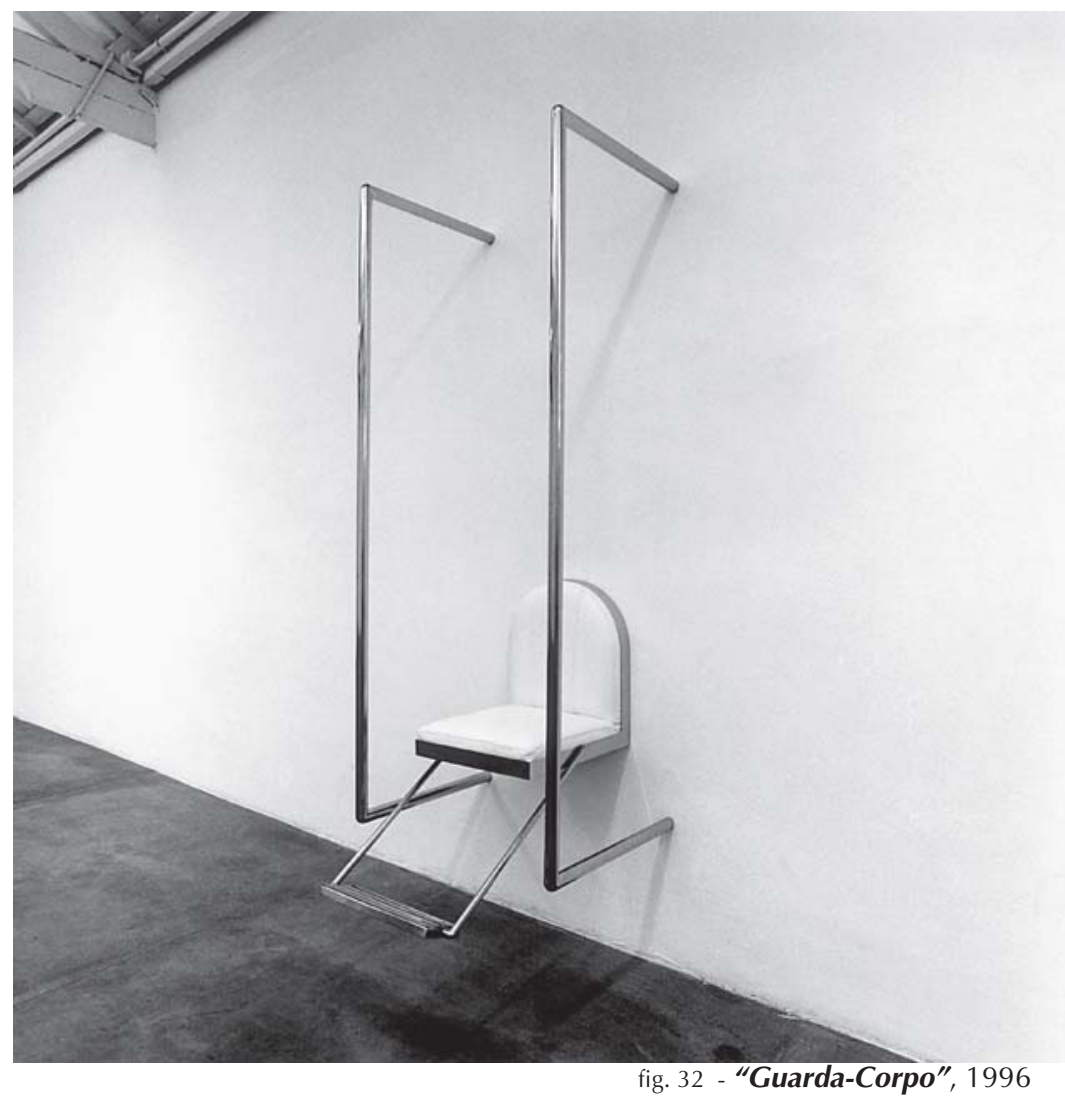

\footnotetext{
${ }^{38}$ KRAUSS, Rosalind E. Opus cit., pp. 137-138.

${ }^{39}$ Como sugere Martin Grossmann, "(...) arte não é apenas um objeto (quadro, escultura, gravura), mas uma criação coletiva formadora de espaços-tempos sincrônicos (interfaces). O momento-arte é (re)criado quando há uma interação entre a proposta-arte do artista, a disposição/presença (estética) do(s) objeto(s) e a participação efetiva (consciente/ intelectual) do usuário (não mais observador). A arte é modelada ou formalizada quando existe uma conectividade entre estas três instâncias mencionadas acima: trata-se de uma net-art". Grossmann observa que o "observador transformado em participante provoca uma reversibilidade epistemológica", e modela o que Hélio Oiticica denominou como totalidade ambiental. "(...) "o participante ao vestir o objeto-arte transforma-se no núcleo central de uma experiência no espaço-tempo, subvertendo assim os a priori do sistema-arte". GROSSMANN, Martin. Opus cit., pp. 3536.
} 
"Visita Guiada com Amigo J9. Para Edemar", resulta da apropriação e adaptação de um carrinho elétrico — do tipo usado para deficientes físicos- bem como da elaboração de uma trilha sonora que inclui os sons e ruídos de aeroportos, restaurantes e outros espaços públicos de passagem. Idealizada para a exposição coletiva "Ao Cubo" (SP 1997) ${ }^{40}$, proporcionava uma visita guiada transformando a obra em um "aid" ou, como aponta o título, um Amigo personificado, o J9, ou espécie de assistente solidário para eventuais "deficiências" ou impossibilidades de seu condutor. Uma vez disponibilizada para o uso, "Visita Guiada" permite que o usuário percorra o espaço da exposição à uma velocidade adaptada para simular uma travelling-camera, tal como as usadas no cinema, especialmente nos documentários. O áudio reproduzido através de cd player e fones de ouvido acoplados ao carrinho, toca continuamente até que o usuário termine sua jornada. O repertório musical escolhido para a trilha sonora é formado por melodias características de lounge-music e pela musak, que são arranjos "light" especialmente criados para compor o acervo de músicas usadas em elevadores, salas de espera e aeroportos.

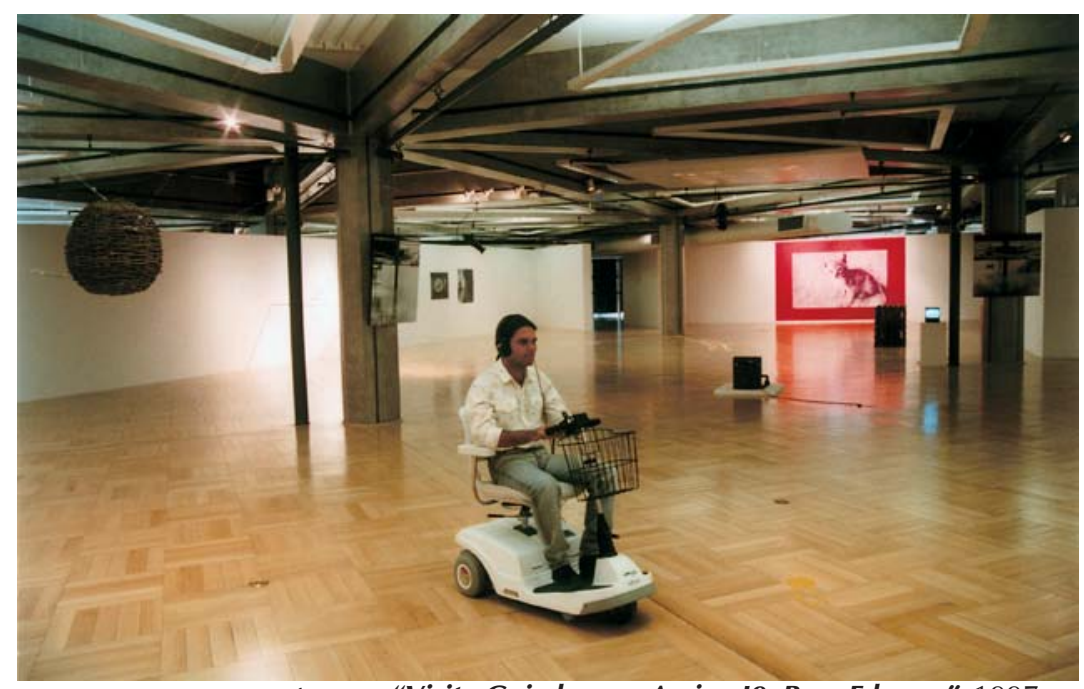

fig. 33 - "Visita Guiada com Amigo J9. Para Edemar", 1997

${ }^{40}$ Exposição coletiva idealizada e organizada por Martin Grossmann e Luciana Brito no Paço das Artes, São Paulo, SP, em março de 1997, cujo objetivo era o enfoque na reflexão a respeito da relação entre arte e contexto, vista a partir dos significados gerados pelo "cubo branco", o espaço neutro e protegido, instituído pelo Modernismo. 
O movimento motorizado do carrinho e a trilha sonora tinham a função de promover, principalmente, dois tipos de deslocamento: o primeiro real, obtido através de uma "máquina motora", que substitui o esforço físico pelo passeio confortável do usuário e, o segundo, virtual, proporcionado pelo áudio que simula uma experiência locada em um espaço de trânsito —o aeroporto. A partir desses deslocamentos simultâneos, "Visita Guiada" possibilita a fusão de três paisagens distintas: a do ambiente real, percebido sobretudo através do olhar, a paisagem sonora que é proporcionada através da experiência virtual de um espaço de trânsito, e a "paisagem" da memória, resgatada do acervo de experiências pessoais do usuário. Ao colocar a realidade objetiva temporariamente em suspensão, a obra proporcionava uma experiência prolongada de espaço-tempo.

Como "Visita Guiada", o aparelho "Exit"41 tem no áudio o elemento destinado a propiciar a experiência virtual de deslocamento. Inspirado nas escadas de aviões habitualmente usadas nos aeroportos para o embarque dos passageiros, "Exit" reposiciona o olhar do usuário a, aproximadamente, quatro metros do chão. É desse lugar, uma pequena plataforma, que se poderá ouvir, através de fones de ouvidos, um repórter aéreo sobrevoar São Paulo, com informações precisas sobre o trânsito caótico da cidade. Colocados no ar nos intervalos das programações das estações de rádio, esses repórteres do espaço urbano cumprem a função de facilitar a vida da população em trânsito, oferecendo possíveis saídas ou meios de se evitar um pior congestionamento em locais críticos. A condição paradoxal dessa escultura-aparelho foi reforçada através da montagem do áudio. Elimina-se o contexto - a programação musical, as propagandas e os comentários do locutor-para que o usuário, através de uma experiência de caráter sinestésico, produza mentalmente um mapeamento visual da cidade, a partir da paisagem sonora que é dada de maneira compulsiva e initerrupta, apenas modelada pelos fragmentos de uma música new age.

\footnotetext{
41 "Exit" foi exposta pela primeira vez em "Território Expandido", mostra idealizada por Angélica de Moraes como homenagem aos finalistas do "Prêmio Multicultural Estadão" e realizada no SESC Pompéia, em São Paulo, 1999.
} 


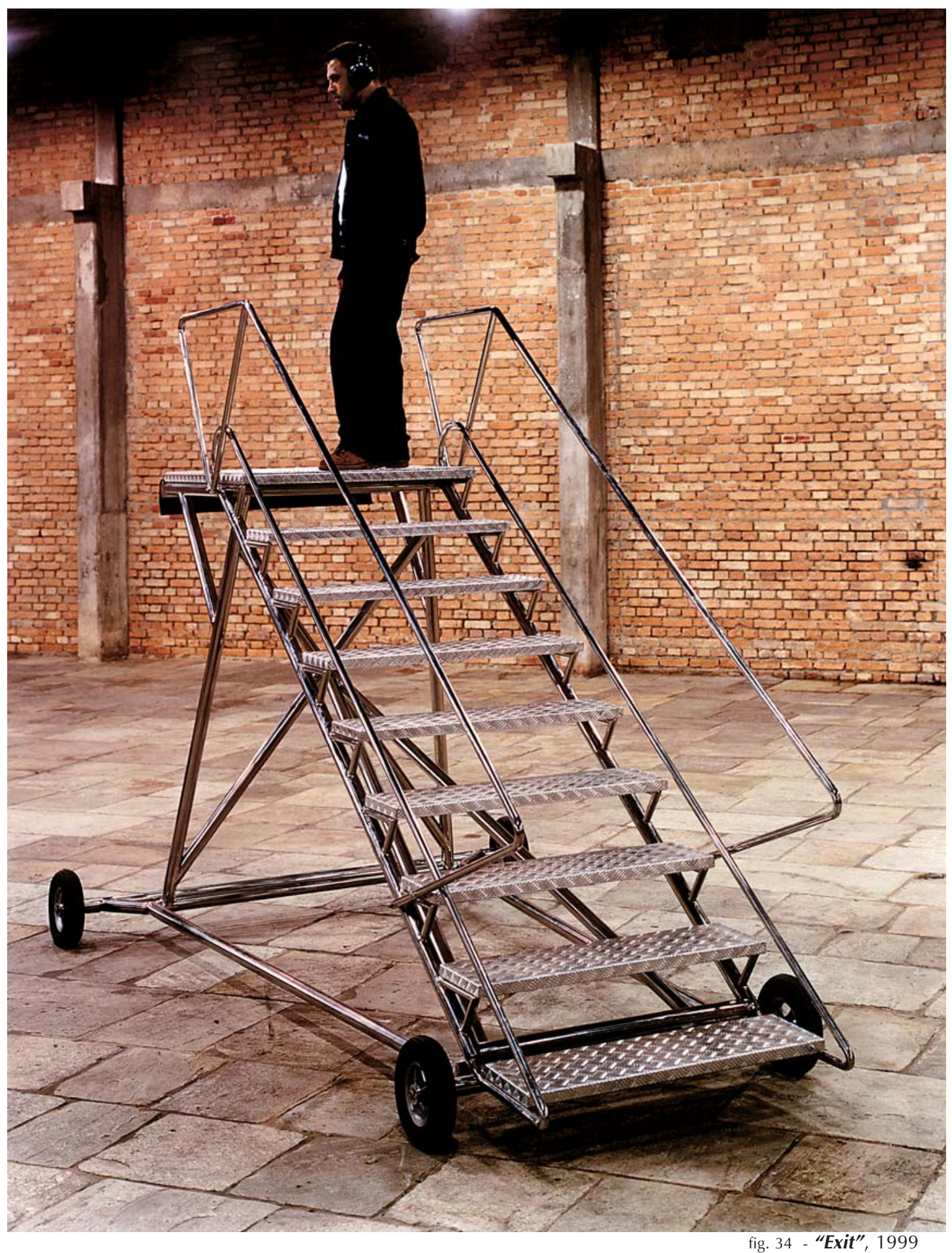


Contudo, em oposição à crença moderna de que era possível equipar o homem para que ele se fizesse o "mais que perfeito" ou "magnificente" através de próteses que o tornariam abundantemente habilitado, temos hoje consciência plena de nossa própria limitação e submetemos cada ação a um cálculo preciso dos riscos implicados. ${ }^{42}$ É nesse sentido que "Exit" irá retomar a "sensação de fracasso" sugerida em obras anteriores. Ao invés de afirmar a escada como uma possibilidade de saída ou de acesso, sua descontextualização (do campo de pouso para o espaço institucional da arte) aliada ao deslocamento proporcionado pelo áudio, tem o objetivo de possibilitar a experiência de uma situação quase claustrofóbica, pois o usuário perceberá que não há saídas e, embora o título anuncie "Exit", ele será flagrado no espaço-tempo da obra em uma situação de risco e de fracasso: a obra não pretende oferecer amparos.

${ }^{42} \mathrm{~A}$ idéia do risco relativa à vida experiência contemporânea foi tratada anteriomente (supra 30-30). 


\subsection{O SITE, O SITE-SPECIFIC E O SITE-SPECIFIC DESLOCADO: O CONFLITO expandido — "Gambling", "Porto Pampulha", e "Relax'o'visions"}

Para tratar das exposições "Gambling", "Porto Pampulha" e "Relax'o'visions" será preciso antes fazer uma análise de como a noção que temos hoje de espaço é relevante para a compreensão da produção artística de nosso tempo e, em especial, daquela que se constitui como o núcleo central dessa tese. Para tal, irei estabelecer relações entre o pensamento de Michel Foucault, Marc AuGÉ, e de autores que analisaram a arte produzida nesse século, bem como uma visão poética de Robert Musıl a respeito do espaço na vida moderna e contemporânea. Subdividindo o tema aqui apresentado em quatro partes —a experiência do espaço, do espelhamento, do não-lugar e, finalmente, o leque das experiências que levam do site ao site-specific deslocado-, tenho como objetivo apresentar as idéias que iluminaram minha prática artística e proporcionaram as bases conceituais para uma reflexão a partir de um ponto de vista que extrapola os parâmetros da própria arte. Esse exercício teórico serviu para adensar o que já havia sido batizado, através da produção prática, como o site-specific deslocado.

\subsubsection{A EXPERIÊNCIA DO ESPAÇO}

"A era atual será talvez e sobretudo a era do espaço". Com essa afirmação Foucault coloca o espaço como a questão central e modeladora dos aspectos mais significativos da cultura do século XX, contrariando a noção historicista e a visão diacrônica de mundo que tanto caracterizou o século anterior. Em um ensaio chamado "Of Other Spaces", Foucault nos fala de maneira sintética:

Estamos na era da simultaneidade: estamos na era da justaposição, do perto e do longe, do lado-a-lado, do disperso. Estamos em um momento, acredito, em que nossa experiência do mundo é menos aquela de uma vida longa que se desenvolve através do tempo, do que a de uma rede que conecta pontos e se intercepta em seu próprio emaranhado. ${ }^{43}$

${ }^{43}$ Foucault, Michel. "Of Other Spaces" in MirzoefF, Nicholas (org.) The Visual Culture Reader. London: Routledge, 1998, p. 237. 
Nesse ensaio, Foucault analisa o desenvolvimento histórico da noção de espaço. A primeira grande mudança rumo à concepção moderna de espaço teria sido conseqüência da descoberta de que a terra se move num espaço contínuo (Galileu) ao invés de permanecer estável no centro do universo. Não se deve subestimar as repercussões que teria essa nova concepção da ordem cósmica para o entendimento, principalmente a partir do século XVIII, da natureza e da organização da vida como um todo. A conseqüência mais radical do pensamento de Galileu é, conforme Foucault, a instituição de um infinito, isto é, a percepção de que o espaço é infinitamente aberto. A partir de então o espaço passaria a ser percebido como extensão, substituindo a noção medieval de espaço como localização (emplacement), que era baseada nas hierarquias, nas oposições e na concepção do lugar como um ponto fixo e estável. O espaço como extensão implica a dissolução do lugar como tal, uma vez que "o lugar de uma coisa nada mais era que um ponto de sua trajetória" ${ }^{44}$.

Mas Foucault observa ainda que para chegarmos à noção que temos hoje de espaço seria necessária ainda outra transformação radical: o espaço deixa de ser entendido como extensão e passa a ser visto como um conjunto de interrelações entre os pontos de um sistema que se constitui em rede. A tais pontos chamamos sites. Segundo Foucault, o espaço contemporâneo pode ser definido "pelas relações de proximidade entre pontos ou elementos" 45 . No mundo moderno, o espaço indiferenciado e homogêneo sofre um processo de diferenciação que o compartimentaliza. No entanto essa compartimentalização não restaura o lugar medieval pois a especificidade do site decorre de uma especialização e individualização que se baseia em critérios funcionais/ utilitários, enquanto a especificidade do lugar se funda em oposições de caráter moral (lugares sagrados e profanos, seguros e expostos, celestiais e terrestres, etc $\left.^{46}\right)$. Além disso, por ser espaço de localização o conjunto dos lugares na

\footnotetext{
${ }^{44}$ Idem, p. 238.

${ }^{45}$ Idem, Ibidem.

${ }^{46}$ Idem, pp. 237-238.
} 
Idade Média não se constituía como uma rede mecanicamente estruturada ${ }^{47}$ simplesmente a cada coisa se atribuía um lugar.

O que Foucault mostra em sua análise da estruturação do espaço na vida atual (note-se que seu ensaio data de 1967) é explicitado poeticamente em $\underline{\mathrm{O} \text { Homem }}$ $\underline{\text { sem Qualidades }}^{48}$, romance escrito em 1938, por Robert Musil, que dá conta com precisão de nossa experiência de mundo. Ao descrever uma cidade superamericana MUSIL nos mostra ironicamente a estruturação espacial de uma cidade supermoderna, que submete o indivíduo e suas relações afetivas a uma organização setorizada para privilegiar a produção e a especialização. Devido às relações tão afinadas que esse texto estabelece com as conceituações decorrentes de minha produção artística, optei pela transcrição integral de um parágrafo do capítulo intitulado "Kakânia":

$\mathrm{Na}$ idade em que ainda se levam à sério coisas como alfaiate e barbeiro e se gosta de olhar no espelho, muitas vezes nos imaginamos em algum lugar onde gostaríamos de passar a vida, ou pelo menos um lugar onde é elegante viver, mesmo sentindo que, pessoalmente, não seria tão bom estar lá. Uma dessas obsessões é há muito tempo uma espécie de cidade superamericana, onde todo mundo corre ou pára com cronômetro na mão. Céu e terra formam um formigueiro varado pelos diversos andares de ruas sobrepostas. Trens aéreos, trens terrestres, trens subterrâneos, pessoas transportadas por correio pneumático, comboios de automóveis disparam na horizontal, ascensores rápidos bombeiam verticalmente massas humanas de um nível de trânsito a outro; salta-se de um meio locomotor a outro nos pontos de junção, sem pensar, sugado e arrebatado pelo ritmo dos veículos, que entre duas corridas trovejantes fazem uma síncope, uma pausa, uma pequena brecha de vinte segundos; trocam-se algumas palavras nos intervalos desse ritmo geral. Perguntas e respostas articulam-se como peças de máquina, cada pessoa tem apenas tarefas bem determinadas, as profissões estão agrupadas em lugares certos, come-se em pleno movimento, as diversões estão reunidas noutras partes da cidade, e em outros locais encontram-se as torres onde ficam esposa, família, gramofone e alma. Tensão e distensão, atividade e amor são minuciosamente separadas no tempo, e equilibradas segundo experiências de laboratório. Caso haja dificuldade em qualquer dessas ações, simplesmente se larga tudo; pois encontra-se outra coisa, ou eventualmente algum caminho melhor, ou outro encontrará o caminho que nós não achamos; não tem nenhuma importância, uma vez que nada causa tanto desperdício da força comum quanto presumir que se

\footnotetext{
${ }^{47}$ Estas redes mecanicamente estruturadas são o oposto de uma organização de caráter orgânico que define as relações dos indivíduos da Idade Média, ou seja, os espaços não se organizavam pelas especificidades de suas funções, mas por uma inter-relação entre indivíduos, suas atividades e os lugares que delas resulta.

${ }^{48}$ MusIL, Robert. O Homem Sem Qualidades. Rio de Janeiro: Editora Nova Fronteira, 1989.
} 
tem missão de não largar determinado objetivo pessoal. Numa comunidade através da qual correm energias, todo caminho leva a um bom objetivo, desde que não se hesite nem reflita demais. Os objetivos são a curto prazo; mas também a vida é curta, e assim conseguimos arrancar dela o máximo de realização. A pessoa não precisa mais do que isso para ser feliz, pois aquilo que se obtém modela a alma, enquanto aquilo que se deseja, sem conseguir, apenas a deforma; para a felicidade importa muito pouco o que se deseja, mas apenas que seja obtido. Além disso, a zoologia ensina que de uma soma de indivíduos reduzidos pode resultar um todo genial. ${ }^{49}$

No texto de MusıL, percebemos que não se trata de um futuro distante, mas que o século XX inventa e reinventa, desde cedo e de forma acelerada, uma estrutura que organiza e regula os espaços e a vida de forma mecânica, como uma engrenagem que visa não mais suprir as necessidades de indivíduos, mas modelar o fluxo cada vez mais veloz e o funcionamento da coletividade. Perdemos assim a capacidade de perceber o espaço como infinito e homogêneo (Galileu) e só nos damos conta dos sites especializados e das relações entre eles: "Nossa época é uma na qual espaço toma para nós a forma de relações entre os sites" 50

Segundo Foucault, a questão que se coloca em relação ao site não se refere apenas a um problema de demografia, à distribuição das pessoas no espaço do mundo, mas de "sabermos quais relações de proximidade, quais tipos de armazenagem, circulação, marcação e classificação de coisas humanas deveriam ser adotados em uma situação dada a fim de alcançar a meta esperada" ${ }^{\prime \prime 1}$. É interessante comparar essa colocação de FOUCAULT com o trecho citado de MusıL — note-se o pressuposto utilitário presente em ambos.

Não é novidade que "espaço" é também a palavra-chave para arte do século $X X$, a qual parece refletir o modo como ele se organiza para nós na contemporaneidade. Conforme descreve Brian O'Doherty em uma série de

${ }^{49}$ Idem, pp. 24-25.

${ }^{50}$ Foucault, Michel. Opus cit., p. 238.

${ }^{51}$ Idem. Ibidem. "coisas humanas", no inglês: "human elements". 
ensaios a respeito da relação entre arte e espaço,

a história do modernismo está intimamente emoldurada pela história do espaço (da galeria); ou ainda, a história da arte moderna pode ser correlacionada às mudanças nesse espaço e na forma com que o vemos. Chegamos a um ponto tal que não vemos a arte mas o espaço primeiro. ${ }^{52}$

Como bem caracterizou Rosalind KRAUSS ${ }^{53}$, o desenvolvimento da escultura do século XX é exemplar para mostrar que a experiência da arte está intimamente ligada àquela do espaço ${ }^{54}$. Segundo a autora, a passagem dos significados da escultura, da sua estrutura interior, privada e idealizada, para as relações que estabelece com seu espaço externo, público, acaba por determinar que a obra não se completa nela mesma mas estará sempre em relação com seu entorno. Ao contrário de privilegiar o objeto como um circuito fechado de significações, a produção artística caminhou rumo à definição daquilo que conhecemos hoje como o site-specific, ou seja, a obra cuja origem e significação está intimamente ligada às características intrínsecas do lugar.

Bem, se Foucault nos fala que a organização da vida passa a ser regulada por conjuntos de sites especializados formando uma rede, é interessante perceber como na arte também é o específico, as relações entre obra e espaço, que será tematizado. Dessa forma, quando a arte se "cola" no site, ela começa a fazer parte da rede, tal como explicada por FoucAult, e a experiência da arte se sobrepõe à da vida e vice-versa.

Com efeito, na medida em que o espaço se especializou, a obra de arte deixou de ser indiferente à essa especialização, e passou a incorporar os atributos originais de seu contexto. Além disso, o sujeito submetido à experiência da

\footnotetext{
${ }^{52}$ O’Doherty, Brian. Opus cit., p. 14. O itálico é meu.

${ }^{53}$ Krauss, Rosalind E. Opus cit.

${ }^{54}$ A experiência de espaço implica uma relação com o tempo, mas ainda assim a experiência do espaço parece predominar. Em relação à experiência do tempo em nosso século FoucAult comenta: "o espaço tem uma história na experiência ocidental e não é possível desconsiderar a interseção fatal do tempo com o espaço". (...) "De qualquer forma eu acredito que a ansiedade de nossa era está relacionada fundamentalmente com espaço, sem dúvida muito mais do que com tempo. O tempo provavelmente aparece para nós somente como uma das várias operações distributivas que são possíveis para os elementos espalhados no espaço". Foucault, Michel. Opus cit., pp. 237-238.
} 
arte, acabou assimilando a noção de especialização a partir de sua experiência de mundo e, certamente, traz essa referência para o campo da arte. Como conseqüência o artista, de uma forma ou de outra, tende a não mais deixar de levar em consideração as especificidades do site que the serve de contexto. Como observa Thomas McEvilley: "tem sido genialidade especial de nosso século investigar as coisas em relação ao seu contexto, chegar a ver o contexto como formativo da coisa, e, finalmente, ver o contexto como a própria coisa" ${ }^{55}$.

\subsubsection{A EXPERIÊNCIA DO ESPELHAMENTO}

Essas considerações sobre o site e o site-specific são extremamente importantes para a compreensão do meu trabalho pois, aliadas ao entendimento de como se constitui o site que se especializa em arte (galeria/museu e outros), servirão como instrumental crítico para refletir sobre as exposições "Porto Pampulha" e "Relax'o'visions". No entanto, no trabalho, a experiência do site está intimamente ligada à experiência do espelho e, assim sendo, é essa última aquela a ser analisada em primeiro lugar. Para o entendimento de ambas experiências, será útil recorrer ainda a conceitos formulados por FoUCAULT. Ele identifica dois tipos fundamentais de sites na vida contemporânea, que estão em relação a todos os demais mas que, a seu ver, possuem a curiosa característica de:

suspeitar, neutralizar ou inverter o conjunto de relações que eles pretendem designar, espelhar, ou refletir. Esses espaços, por assim dizer, que estão ligados a todos os outros, que no entanto contradizem todos os outros sites, são de dois tipos. ${ }^{56}$

A esses dois tipos, Foucault denominou sites utópicos e sites heterotópicos. As utopias são fundamentalmente espaços irreais; são sites que não se constituem a partir de um lugar concreto, que se caracterizam por estabelecer com a sociedade uma analogia direta ou inversa, a apresentar a realidade de forma perfeita, ou mesmo a sociedade ao revés.

\footnotetext{
${ }^{55}$ McEvilley, Thomas. "Introduction" in O'DoherTy, Brian, cit., p. 7.

${ }^{56}$ Foucault, Michel. Opus cit., p. 239.
} 
As heterotopias podem ser definidas como contra-sites, ou seja, lugares reais que se caracterizam pela exclusão do conjunto de todos os demais sites reais de uma dada cultura e têm a característica de, simultaneamente, "representálos, contestá-los ou invertê-los". São "utopias efetivamente atuadas" 57.

Mas, em que consistiria afinal, a experiência especular? A meu ver, o mais peculiar a respeito do espelho seria sua capacidade de provocar a experiência do "eu me vejo vendo, exposto à mim mesmo" ou, "eu me vejo sendo visto; flagrado", ou ainda, "eu revejo o que já vi antes". Trata-se portanto, de uma experiência potencialmente crítica. De maneira geral, o espelho pode ser entendido como um site, um lugar reservado para a projeção do sujeito e que transforma sua própria noção de espaço e tempo; é, segundo FouCAULt, uma experiência mista e intermediária entre a utopia e a heterotopia. Vejamos a descrição do autor:

O espelho é, afinal uma utopia, pois que é um lugar sem lugar. No espelho eu me vejo lá onde eu não estou, em um espaço virtual, irreal, que se abre por trás da superfície; eu estou do lado de lá, lá onde eu não estou, uma espécie de sombra que fornece a minha própria visibilidade para mim mesmo, que me habilita a verme lá onde estou ausente: tal é a utopia do espelho. Mas é também uma heterotopia na medida em que o espelho existe na realidade, onde ele provoca um tipo de reação na posição que eu ocupo. Do ponto de vista do espelho, eu descubro minha ausência do lugar de onde estou, pois eu me vejo do lado de lá. Começando por este olhar, que é, por assim dizer, dirigido em minha direção, do fundo desse espaço virtual que está do outro lado do vidro, eu retorno em direção a mim mesmo; eu torno a dirigir meus olhos em direção a mim mesmo e a me reconstituir lá onde estou. O espelho funciona como uma heterotopia nesse sentido: ele torna esse lugar que eu ocupo no momento em que eu me olho no vidro ao mesmo tempo absolutamente real, conectado com todo o espaço que o circunda, e absolutamente irreal, pois para ser percebido ele tem que passar através desse ponto virtual que está do lado de lá. ${ }^{58}$

A experiência do espelho poderia ser vista de outras perspectivas. A primeira referência para se pensar o espelho é, provavelmente, o mito de Narciso. MCLUHAN, por exemplo, lança mão dele para argumentar que mergulhar no espelho corresponde a um ato de auto-amputação —Narciso foi paralisado pelo

${ }^{57}$ Idem. p. 239. No original, "effectively enacted utopia". Enacted é difícil de traduzir, o verbo to enact significa "desempenhar o papel de".

${ }^{58}$ Foucault, Michel. Opus cit., p. 239-240. 
anestesiar de suas percepções "até que ele se tornou um servo-mecanismo 59 de sua própria imagem estendida ou repetida. (...) Ele estava entorpecido. Ele tinha se adaptado à sua extensão de si mesmo e tinha se transformado em um sistema fechado" 60 . Neste caso, o sujeito perde o contato com o real.

O raciocínio é coerente; no entanto, é preciso tomar cuidado com a incorporação da explicação mítica em assuntos contemporâneos. Qualquer mito é a representação simbólica de um aspecto da experiência humana. Sua natureza é analógica - o mito de Narciso simboliza o risco de uma perda da própria identidade, é manifestação da tomada de consciência desse risco. A questão é: será que o simbolismo do espelho permanece inalterado em relação ao que era na Grécia há três mil anos? Não é à toa que o nome escolhido para o personagem do mito é Narciso —narkê, em grego, quer dizer "estupor".

Ocorre que o espelhamento é para nós hoje um fenômeno bem mais complexo, capaz de proporcionar, a meu ver, toda uma gama de experiências intermediárias entre o estupor e a auto-consciência. O espelho não é mais apenas mergulho, é também, como já disse, "ver-se vendo" e "ver-se sendo visto". O olhar de Narciso no espelho é um olhar ingênuo, não "informado". Ora, como seria possível, hoje, tal perspectiva? Como diz Mário Perniola, a experiência do sentir na contemporaneidade já não é mais de primeira mão e essa me parece ser a diferença entre o indivíduo contemporâneo e o homem grego que, ao lado da fogueira, contava o mito de Narciso-, nosso sentir é o sentir do já sentido e, portanto, o sujeito "se torna o espelho em que o mundo se olha". Assim o autor define a experiência do sentir:

Todavia, na noção de narcisismo toma-se geralmente em consideração apenas uma orientação da energia psíquica virada para a própria imagem do indivíduo: além de que, muitas vezes, ele é entendido como uma privatização da experiência, como um declínio da dimensão social e pública. Escapa assim o aspecto mais importante e mais inquietante: não só a imagem de nós próprios não

\footnotetext{
${ }^{59}$ Servo-mecanismo ou servo, é um mecanismo de controle automático que tem esse nome pelo fato de estar subordinado à uma fonte de comando externo.

${ }^{60}$ McLuHAn, Marshall. Understanding Media: The Extensions of Men.London: Sphere Books Limited, 1967, p.51.
} 
nos pertence completamente, mas até o modo como a sentimos nos parece de algum modo estranho e, por assim dizer, prefixado. Se para o narcisista o mundo é um espelho em que ele se olha a si próprio, a experiência do já sentido parece ligada ao facto de se tornar o espelho em que o mundo se olha. Por isso, talvez seja menos oportuno falar de narcisismo do que de um especularismo que reflete experiências já prefiguradas.(...) O especularismo é, na verdade, algo de substancialmente diferente da imitação, do conformismo, da heterodireção: não se trata mais de seguir a moda, de adequar-se a um comportamento sugerido pelo ambiente, nem tão-pouco de depender da aprovação dos outros, mas de sentir-se o lugar em que o exterior se espelha. (...) Ser espelho não implica todavia uma absoluta dependência do que se reflete nele: podemos virar o espelho em diferentes direcções, manobrar a sua inclinação, movê-lo de modo a reflectir o que está diante ou atrás de nós. Nesse horizonte afectivo, passado e futuro têm ambos o caráter do já sentido, independentemente dos seus conteúdos. O presente do espelho é o encontro vertiginoso com um outro espelho, a instauração de uma visão em abismo, que reproduz ao infinito a especularidade. ${ }^{61}$

Note-se que trazer o pensamento de Perniola para esta discussão tem também o objetivo de completar a reflexão sobre a experiência do espelho, ao acrescentar às considerações de Foucault justamente o que Ihe falta -levar em conta as especificidades do sentir contemporâneo.

Em minha produção, a primeira experiência relativa ao espelhamento se deu com "Alguns Pássaros (Those in Flight)", em 1991. A obra, além de absorver o seu entorno, reflete a imagem do sujeito em sua superfície cromada. Há um encontro do sujeito consigo mesmo e, a partir daí, essa noção do encontro consigo mesmo se estendeu para a arquitetura, tornando a experiência do espelho muito mais radical em obras posteriores: "Porto Pampulha" (1997), "Relax'o'visions" (1998), "Gambling" (1999) e "Exit com Parede Niemeyer" (1999).

Os espelhos em "Gambling"62 foram pensados para funcionar como uma

\footnotetext{
${ }^{61}$ Perniola, Mário. Do Sentir. Lisboa: Editorial Presença, 1993, p. 19-20. Os negritos são meus. A “instauração de uma visão em abismo", refere-se à expressão "en abîme" que significa que uma parte repete o todo; por exemplo, num romance em abismo o todo figura em uma de suas partes.

62 "Gambling" é o título da obra realizada para exposição coletiva "Il Semana Fernando Furlanetto: Fotografia", realizada no Teatro Municipal de São João da Boa Vista (São Paulo), pela prefeitura local, em 1999. A mostra, coletiva, contou com a apresentação de trabalhos realizados em suportes variados. O Teatro, que foi inaugurado em 1914, é um 'modelo clássico de teatro de ópera, com $1130 \mathrm{~m}^{2}$ de área construída. Foi adquirido e parcialmente restaurado pela prefeitura municipal e tombado pelo CONDEPHAAT". (Trecho extraído do dossiê apresentado aos artistas para a idealização das obras). Ainda hoje não foi completamente restaurado e permanece fechado.
} 


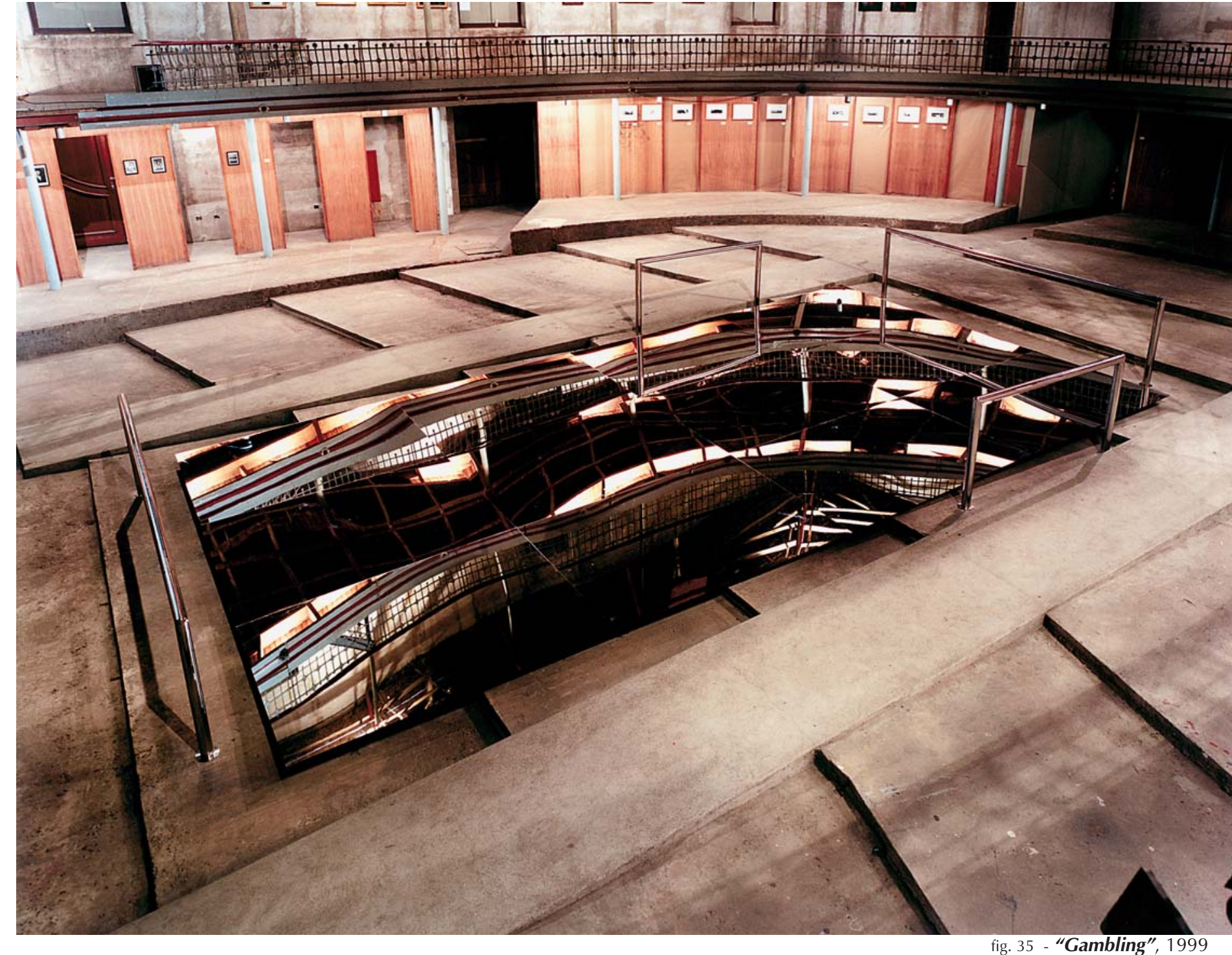

fig. 35 - "Gambling", 1999

armadilha que capturava dentro de si própria os vestígios de um teatro, as lembranças deixadas por uma estrutura arquitetônica desnudada. Ampliava, em uma superfície espelhada, toda extensão do teto e outros detalhes da arquitetura. Composta por $32 \mathrm{~m}^{2}$ de espelhos colocados em um plano inclinado do chão, tinha o objetivo de absorver a arquitetura e proporcionar ao visitante uma espécie de contemplação abismal. Ao redor desse plano espelhado foram instalados quatro corrimãos de aço inox, anteparos para uma experiência vertiginosa no interior do teatro. Inserida no contexto de uma exposição coletiva, cujo tema central era a fotografia, "Gambling" pretendia ampliar os conceitos inerentes a esse processo mecânico de registro do real, capturando o espaço dado para, ao mesmo tempo, revelar a condição daquele teatro: um monumento apagado pelo tempo e pela história. 


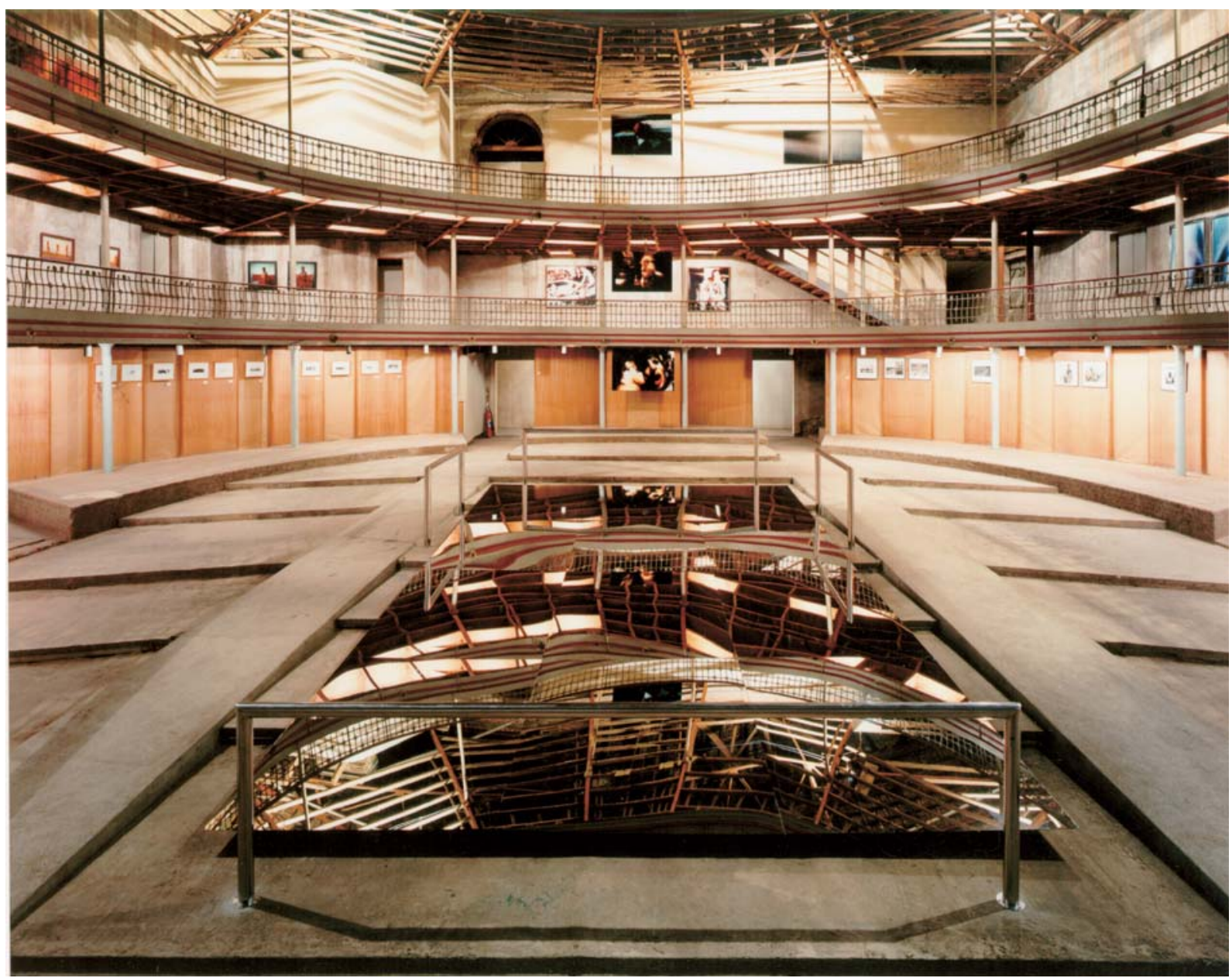




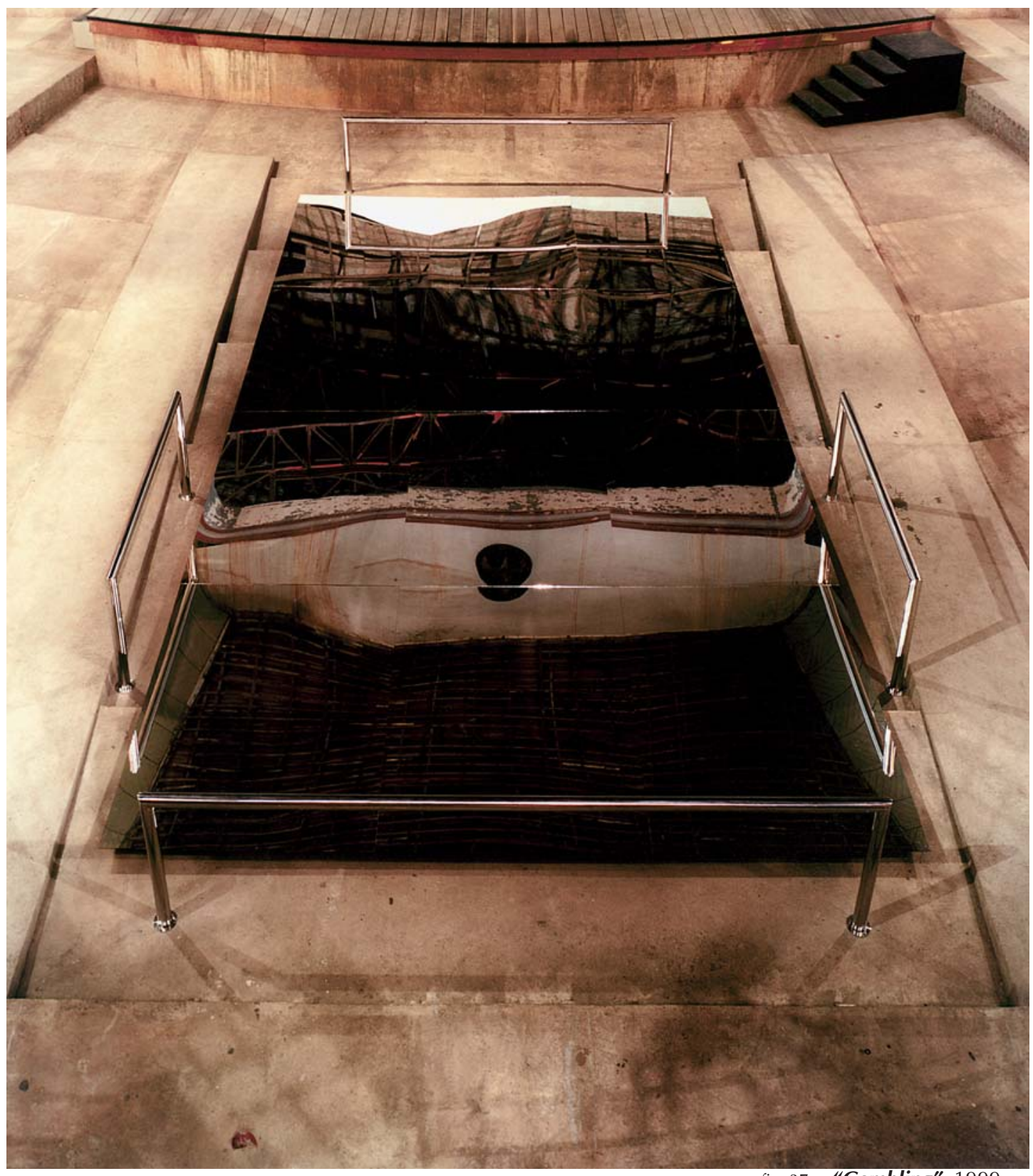

fig. 37 - "Gambling", 1999 
A exposição idealizada para o antigo Cassino da Pampulha, que abriga hoje o Museu de Arte da Pampulha, em Belo Horizonte ${ }^{63}$, pretendeu explorar amplamente os significados da experiência especular, através da apropriação dos significados e características daquele site. "Porto Pampulha" foi idealizada tendo como referência básica para sua conceituação o projeto arquitetônico e paisagístico do complexo Pampulha, de Oscar Niemeyer e Burle Marx, respectivamente. Por essa razão, se constituiu, tanto quanto "Gambling", como um site-specific.

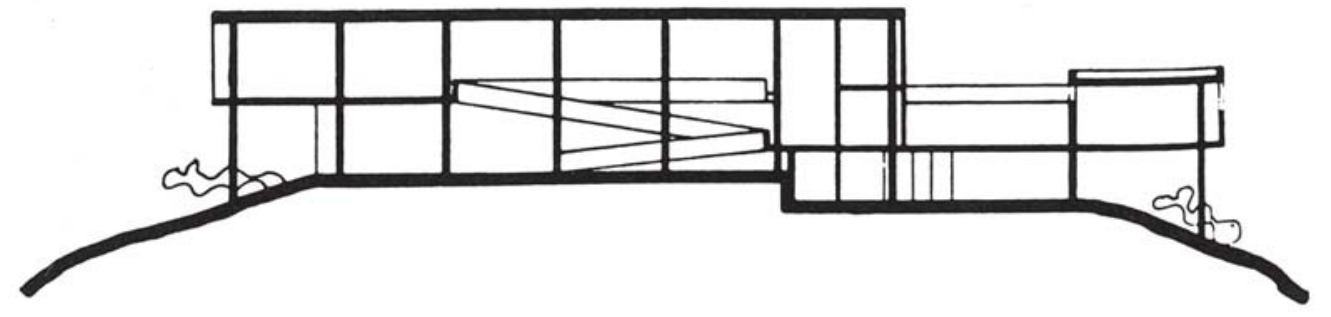

fig. 38 - Cassino da Pampulha (corte lateral)

\footnotetext{
${ }^{63}$ Projetada em 1939-40, a Pampulha é hoje formada por um Cassino, um late Clube, pela Casa do Baile e pela Igreja de São Francisco de Assis, locados ao redor de uma lagoa artificial. A construção de um hotel estava também prevista no projeto inicial, mas nunca se realizou. Anos mais tarde Niemeyer foi convidado a projetar o Pıc —Pampulha late Clube- que foi concebido também com paisagismo de Burle Marx. Localizada a quinze quilômetros do centro de Belo Horizonte, a Pampulha deveria ser, na visão do então governador Benedito Valadares e do prefeito Juscelino Kubitschek, um centro de lazer e diversão para uma elite industrial e de novos ricos da cidade.

Como esclarece David UNDERWOOD, é interessante notar que Juscelino Kubitschek, entusiasmado com o projeto de transformar a capital mineira, decide convidar o urbanista francês Alfred Agache para estudar a área da Pampulha e propor um projeto urbanístico. Ao fazê-lo, "Agache se surpreende com a monumentalidade clássica do planejamento do centro da cidade de Belo Horizonte mas, ao mesmo tempo se choca com o subdesenvolvimento dos distritos da periferia. Sua proposta foi então a de que a Pampulha fosse transformada em uma cidade satélite para abrigar a classe operária da cidade. Kubitschek, consciente da necessidade de um suporte político da burguesia industrial, rejeitou a proposta em favor de seu sonho (e daquela burguesia) de construir um bairro afastado para a elite. A modernidade na Pampulha veio a se constituir então de uma utopia artificial, um centro de prazer e diversão para a classes mais altas" (UNDERWOOD, David. Oscar Niemeyer and the Architecture of Brazil. New York: Rizzoli. 1994, pp. 50-51). Uma "utopia efetivamente atuada", diria Foucault —a Pampulha foi criada como uma "heteotopia de compensação". Considerada hoje como um núcleo turístico de Belo Horizonte, a Pampulha abriga, além dos espaços constituintes do projeto inicial, vários outros clubes de lazer, restaurantes, um estádio de futebol (Mineirão), um estádio poliesportivo (Mineirinho), além do campus da Universidade Federal de Minas Gerais. Foi ali que também se instalou o único aeroporto que administrou, com exclusividade, o tráfego aéreo da cidade de 1936 até 1984, ano em que foi inaugurado o Aeroporto Internacional de Confins, fora do município da capital mineira. Atualmente, além de casas luxuosas espalhadas por sua vizinhança, há também uma enorme quantidade de favelas e loteamentos ilegais sem
} 
O Cassino tem sua arquitetura sustentada por pilotis delgados que sugerem, ao visitante, uma extrema leveza e elegância, além de privilegiar a vista da lagoa de um ponto elevado. Uma das características especiais desse projeto é a relação que estabelece entre o ambiente interno, através de suas paredes de vidro e espelho, e o espaço externo, dominado pela água que circunda o prédio do cassino. É a

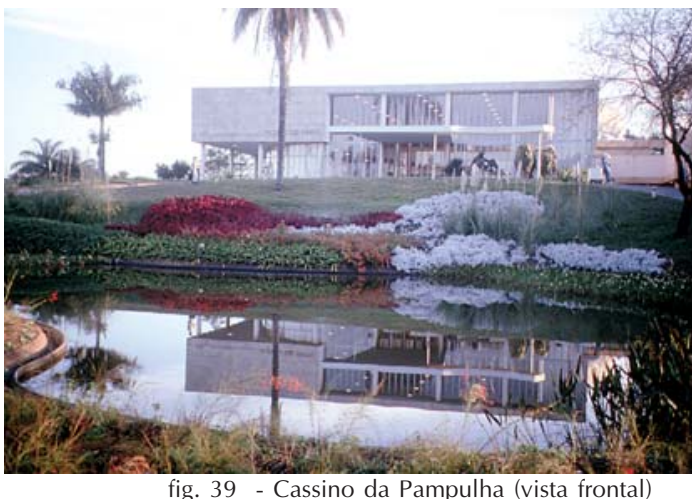
exaltação de uma "natureza artificial", construída e dominada pelo homem moderno. Os principais materiais de acabamento são o vidro, o aço inox, o alabastro e o mármore. A ressonância do espaço é percebida através dos inúmeros reflexos produzidos pelas superfícies espelhadas e pela enorme superfície de vidro que possibilita, de todos os cantos do espaço, uma visão para a água. As inúmeras colunas que se repetem desde o exterior sustentando a laje do mezanino e o teto, são multiplicadas na superfície da parede de espelho, projetada em módulos quadrados em tom rosado. Essa

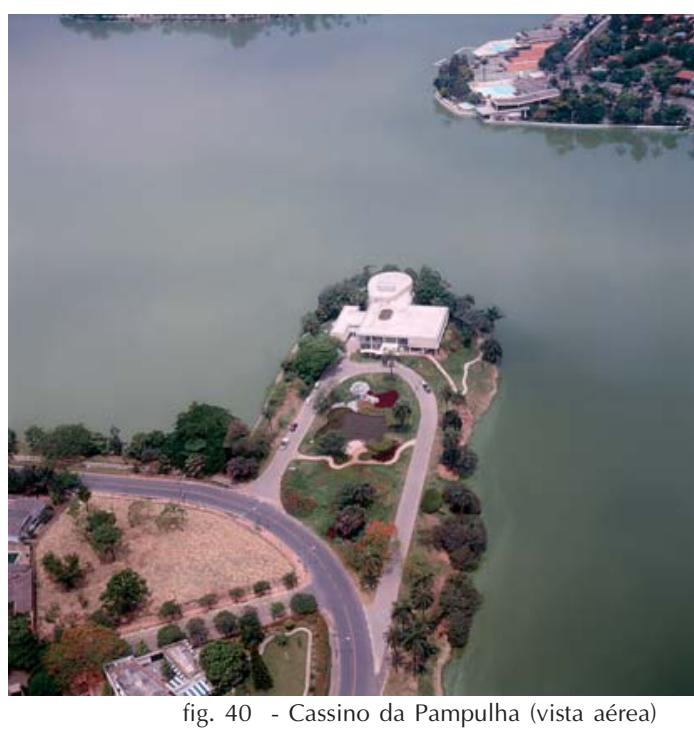
reverberação do espaço externo provocada pela repetição de elementos e pelo reflexo nos vidros e espelhos, provoca a experiência de uma arquitetura moderna de caráter barroco — Le Corbusier diria a respeito de Niemeyer: "Você faz barroco em concreto reforçado, mas você o faz muito bem" ${ }^{64}$.

infra-estrutura básica. A lagoa está poluída. Se, por um lado, a Pampulha ainda pretende ser o cartão postal da cidade, como desejaram seus idealizadores, esse projeto utópico fortemente associado à interesses políticos e à realidade brasileira da "era Kubitschek", é hoje porta-voz de uma falência dessa mesma utopia que a instituiu.

De acordo com David UnDeRWOOD, o projeto da Pampulha nunca se realizou como esperado. Além da proibição dos cassinos, em 1946, decretada pelo então presidente Eurico Gaspar Dutra, da interdição da Igreja, feita pela cúria metropolitana com o apoio da paróquia local, outros problemas surgiram em seguida: a constatação de falhas no planejamento de infra-estruturas básicas, a quebra da barragem e a contaminação das águas da lagoa, entre outros. Os problemas que a Pampulha enfrenta hoje são enormes, e todos eles, conseqüência de uma postura política voltada para a autopromoção. Apesar de tudo ela ainda é um patrimônio que marca o início da verdadeira arquitetura moderna brasileira.

${ }^{64}$ Idem, p. 65. 

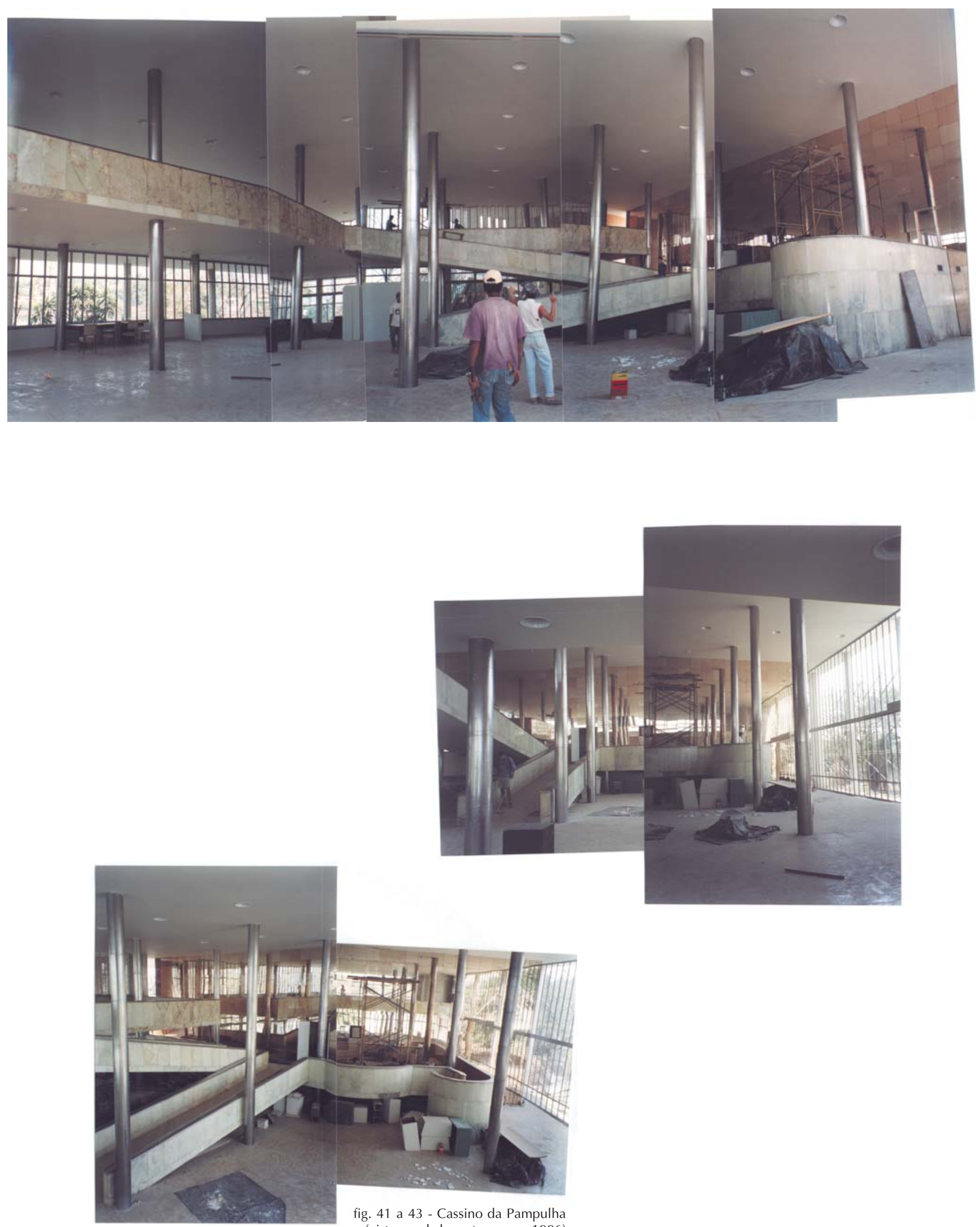

fig. 41 a 43 - Cassino da Pampulha

(vista geral do restauro em 1996) 
É a incorporação das condições próprias de todo o contexto que vai potencializar "Porto Pampulha". Instalada à beira da lagoa e nas proximidades do aeroporto, a exposição pretende propiciar ao visitante (viajante) mais um local de apoio em seu roteiro turístico. O site é transformado em "porto" que incorpora a idéia do deslocamento real e virtual realizados, principalmente, através da escultura-aparelho "Visita Guiada com Amigo J9. Para Edemar". A

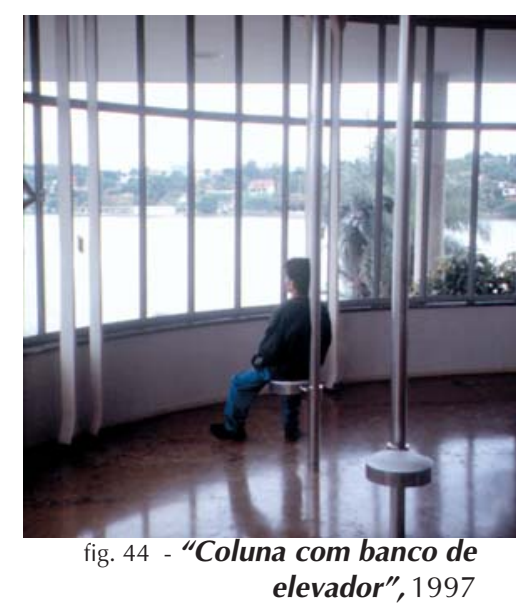
experiência do espelhamento é provocada não só pela arquitetura refletida na lagoa ou pelo enorme painel de espelhos locado no interior do prédio mas, sobretudo, pela repetição de esculturas utilitárias - as estruturas de suporte para o corpo em trânsito e os inúmeros espelhos retrovisores posicionados como se fossem elementos de segurança para a prevenção de acidentes, ou de vigilância (da arte, da arquitetura, do "porto" e de seus usuários) em pontos estratégicos de "Porto Pampulha".

A exposição era composta por vinte e seis obras, realizadas em aço inox, vidro, couro branco, espelho, carro motorizado e áudio, todas conceituadas como estruturas de suporte para o corpo, exceto uma, definida como aparelho. Às colunas originais da arquitetura foram acopladas alças, catracas e espelhos. Além delas, outras colunas (produzidas para a exposição) foram instaladas no espaço: "Coluna com três alças", "Coluna com banco de elevador", "Coluna com roleta". Os títulos das obras ora aludiam aos equipamentos urbanos, ora faziam um comentário a respeito da ambiguidade de suas funções: "Collector's Item", "Museum's Piece", "Carroussel (Para Duchamp), "Visita Guiada com Amigo 19. Para Edemar". Seriam esses objetos de arte para exposição ou equipamentos de um "Porto"? Essas obras ficavam de tal maneira mimetizadas na arquitetura (devido à similaridade dos materiais e ao forte apelo ao design de equipamento urbano), que arte e arquitetura se fundiam, proporcionando estranha experiência de "vazio". 


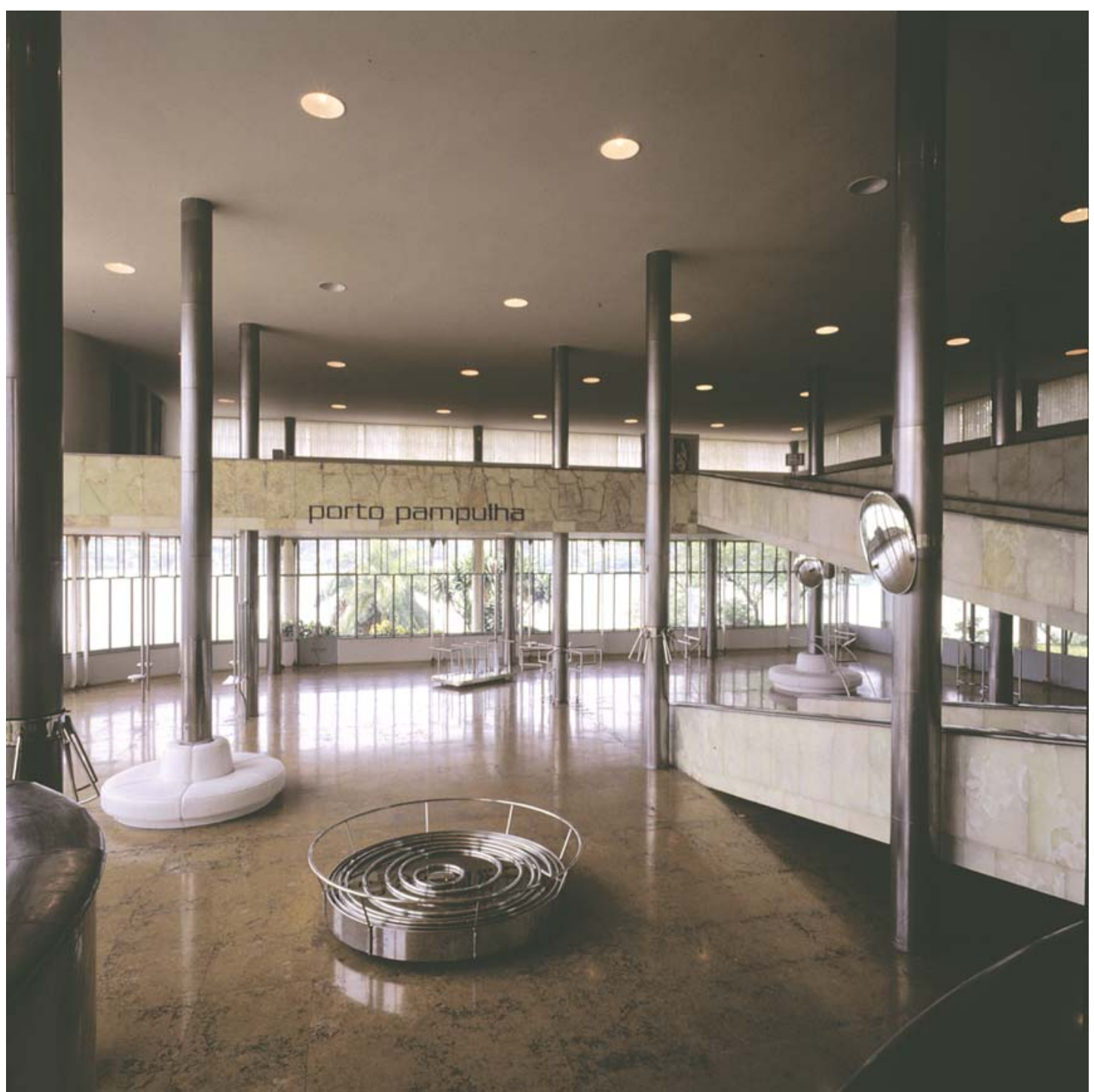

fig. 45 - "Porto Pampulha", 1997 (vista parcial) 


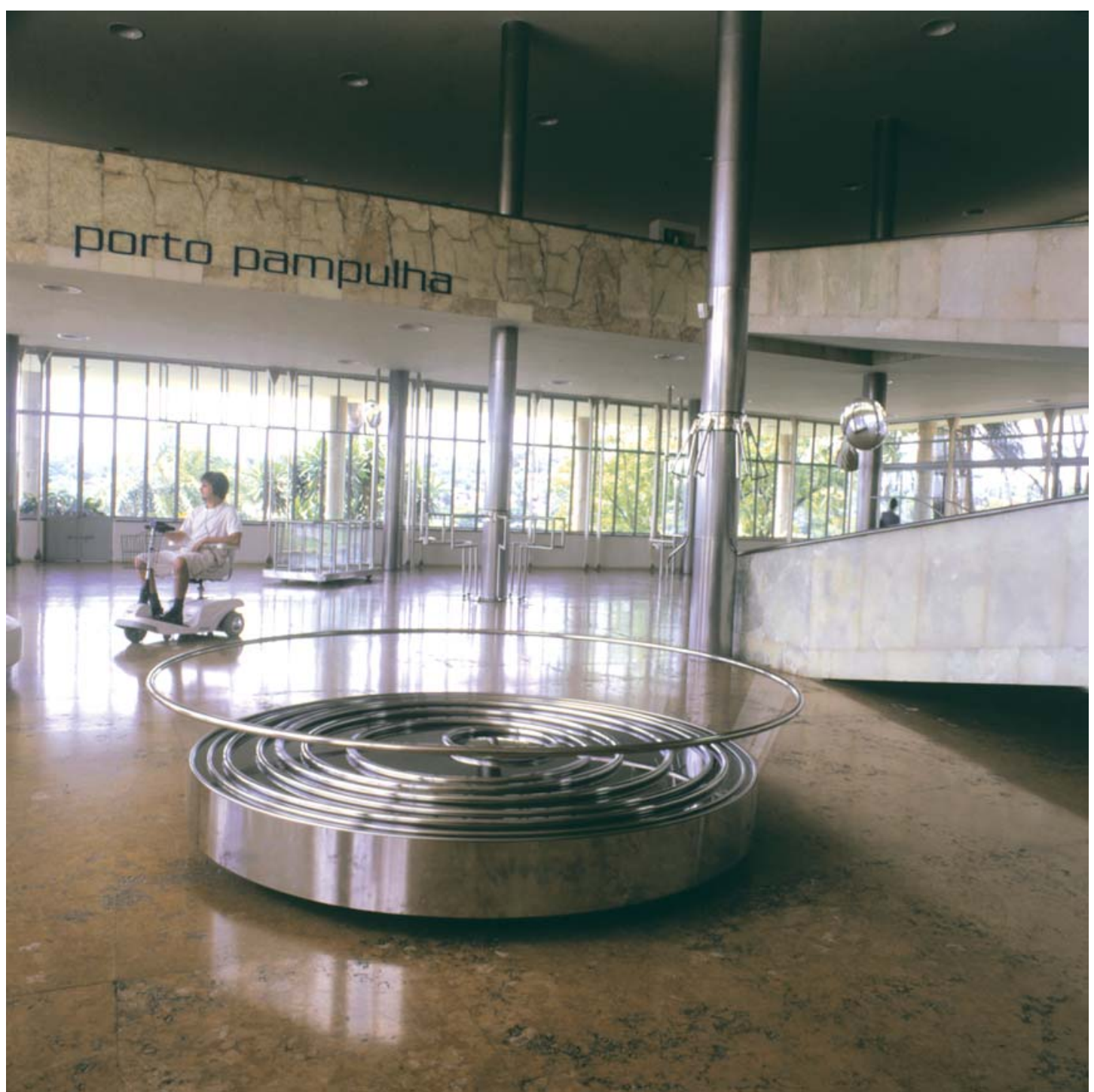

fig. 46 - "Porto Pampulha", 1997 (vista parcial) 


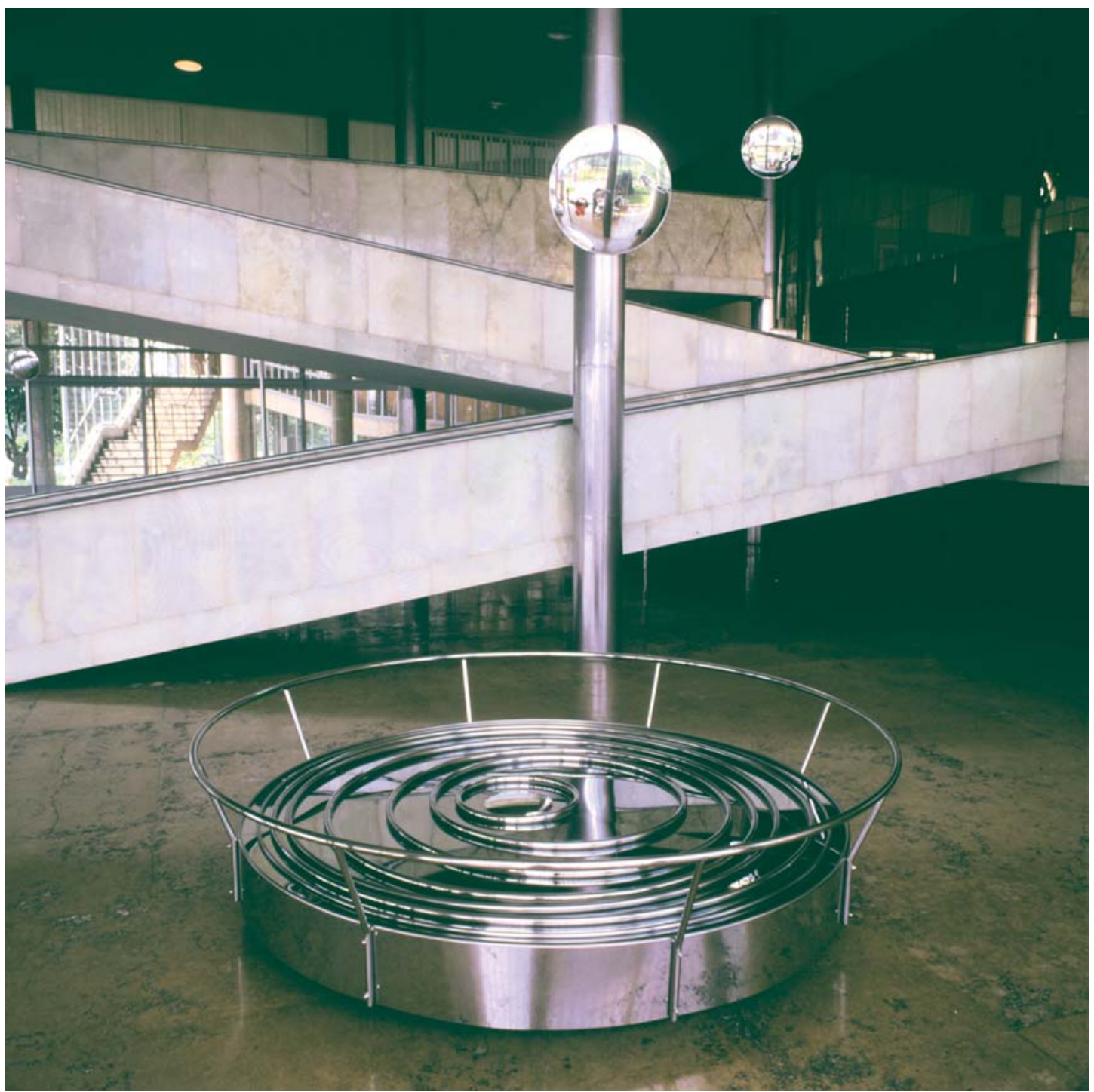

fig. 47 - "Carroussel (Para Duchamp)" e "Coluna com retrovisor", 1997 


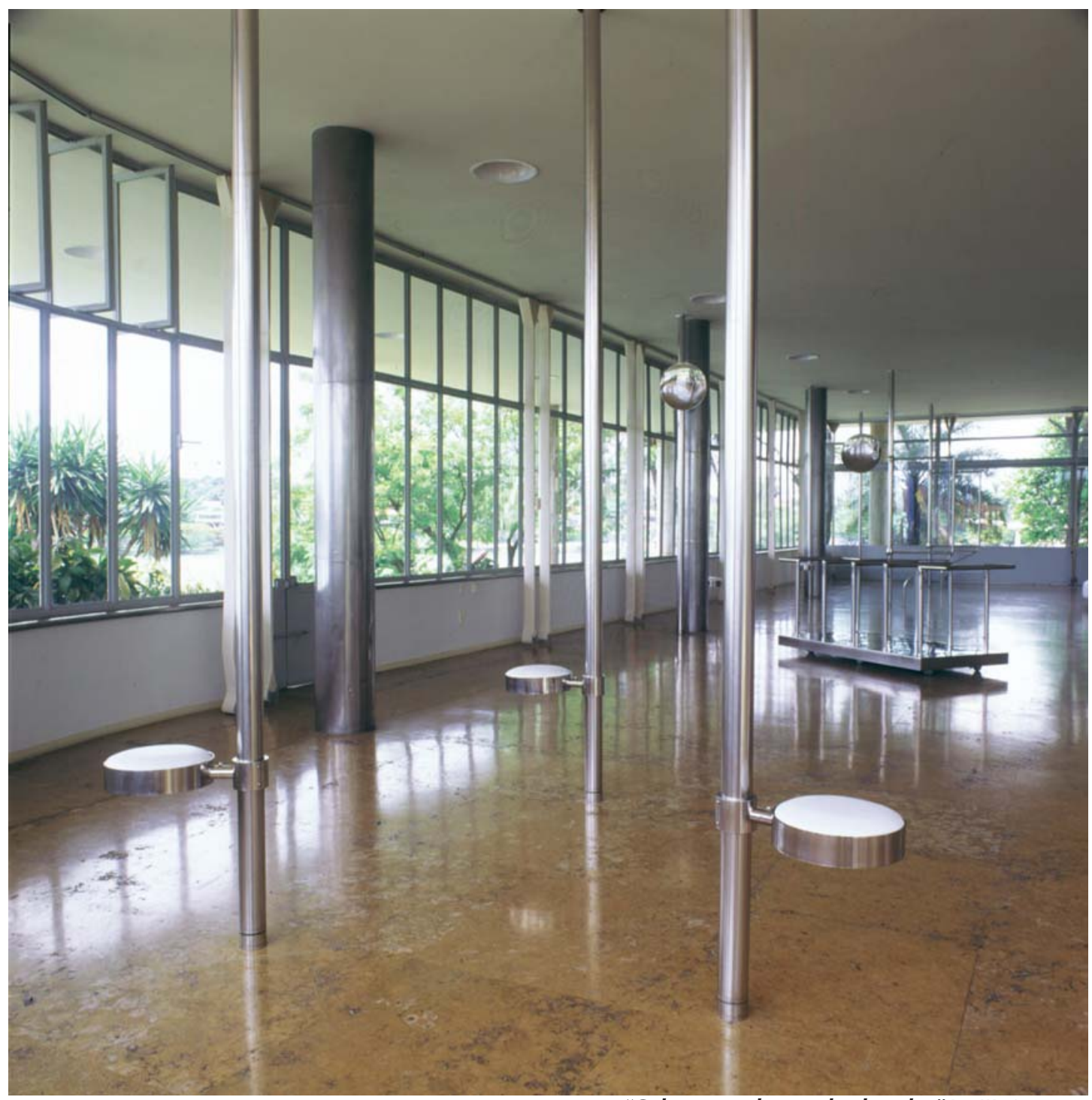

fig. 48 - "Coluna com banco de elevador" I a III, 1997 


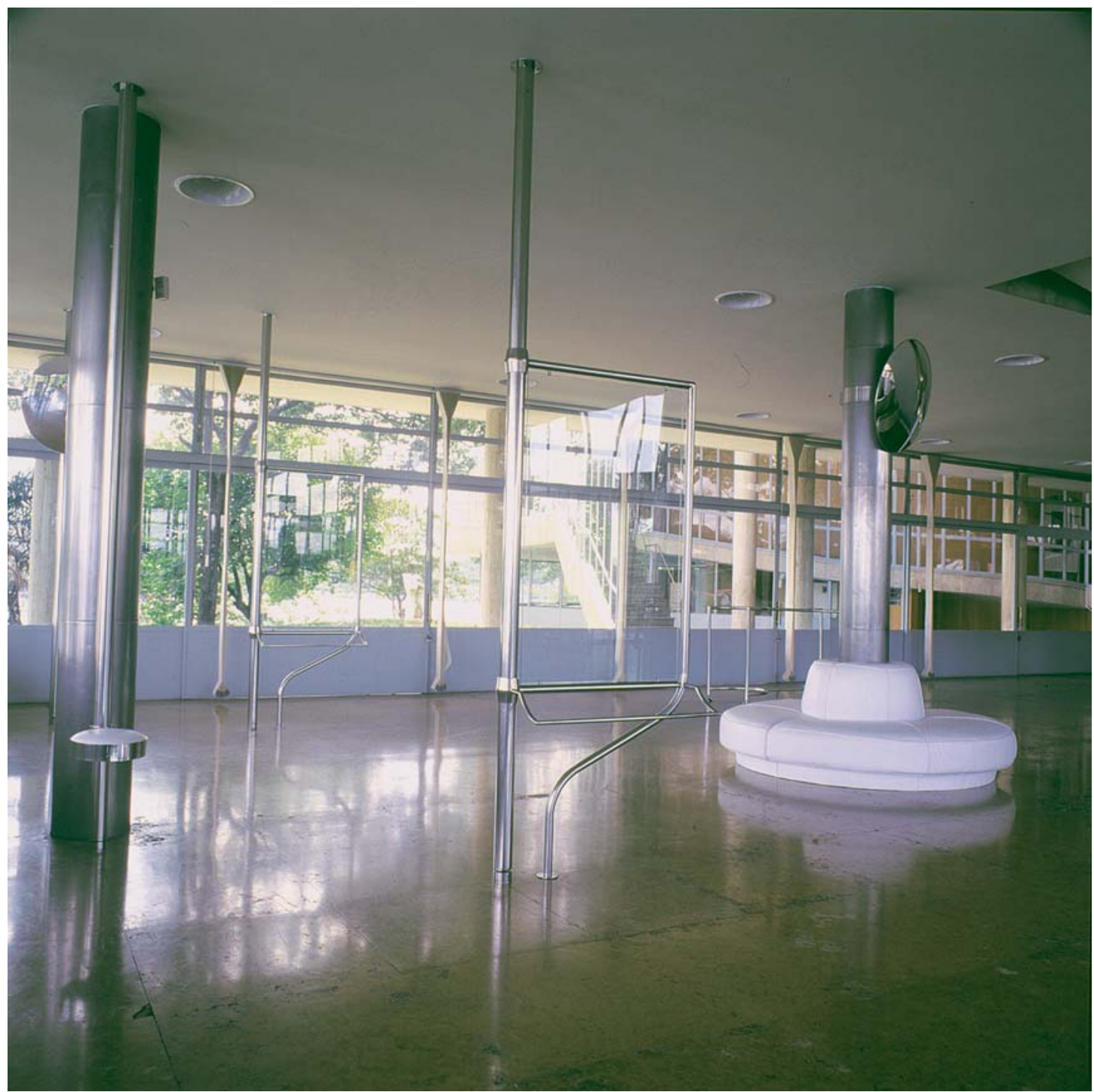

fig. 49 - "Coluna com banco de elevador" e "Coluna com biombo e puxador" I e II, "Collector's Item", 1997 


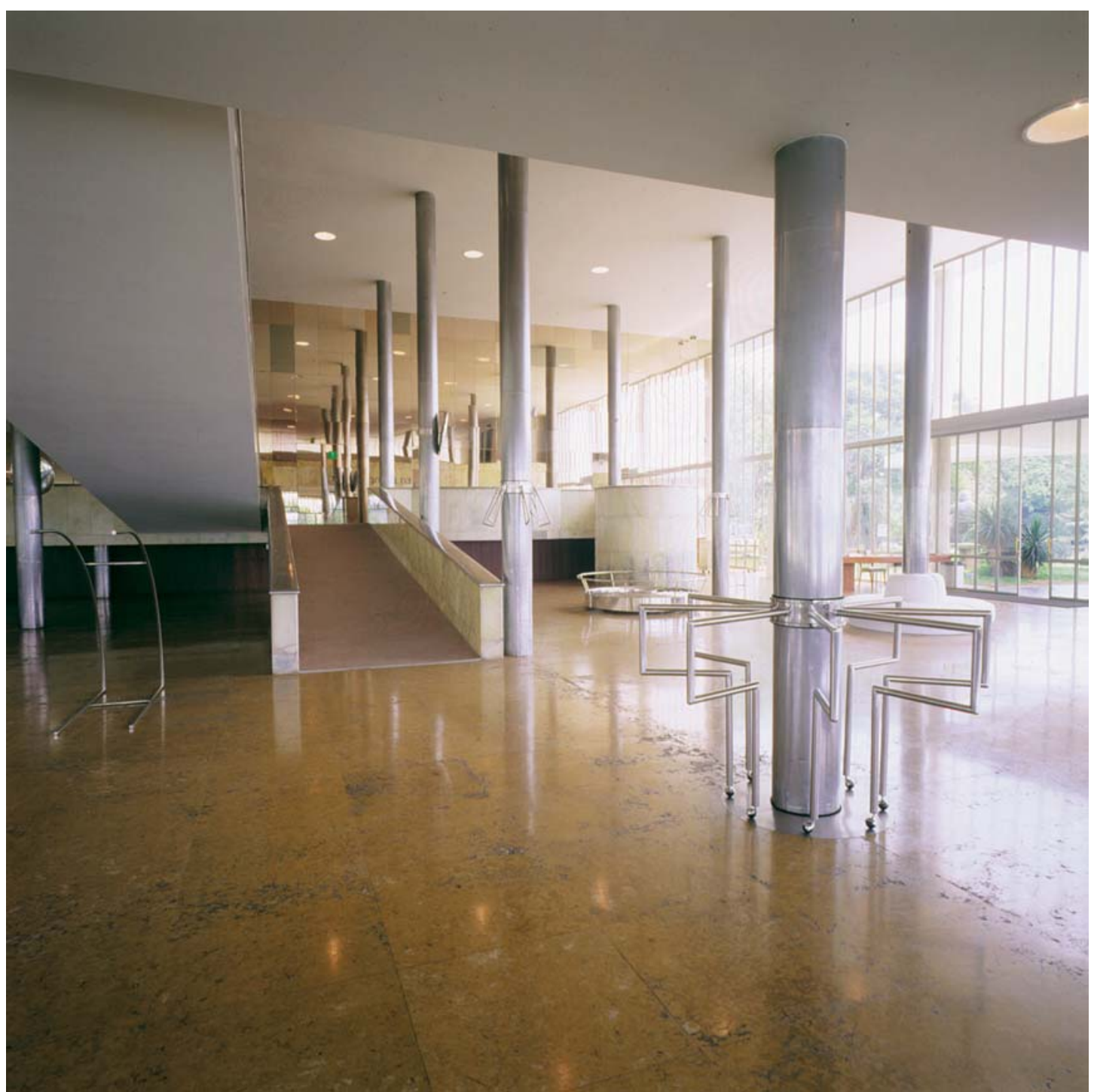

fig. 50 - "Coluna com catraca", 1997 


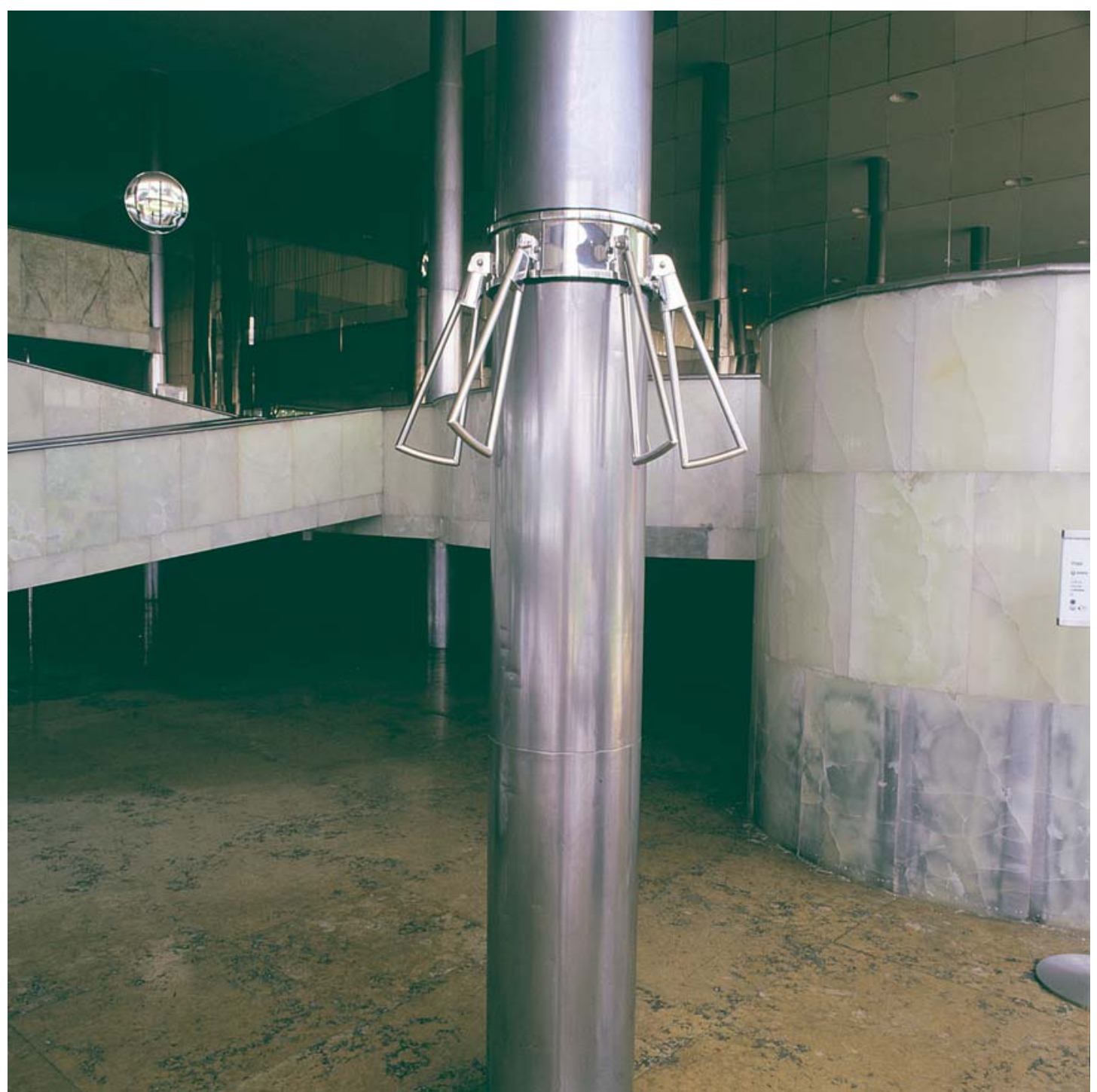

fig. 51 - "Coluna com seis alças" (detalhe), 1997 


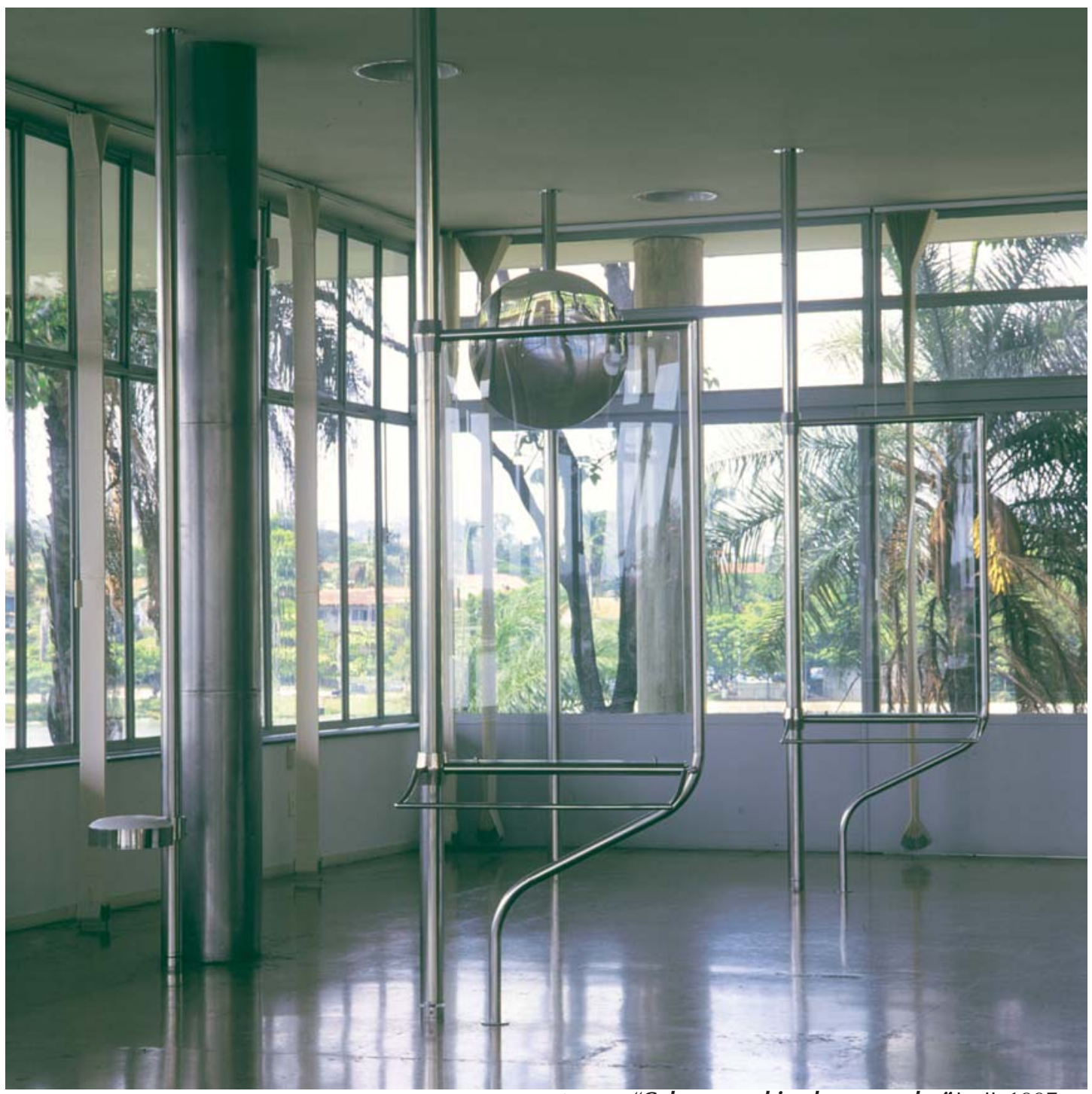

fig. 52 - "Coluna com biombo e puxador" | e II, 1997 

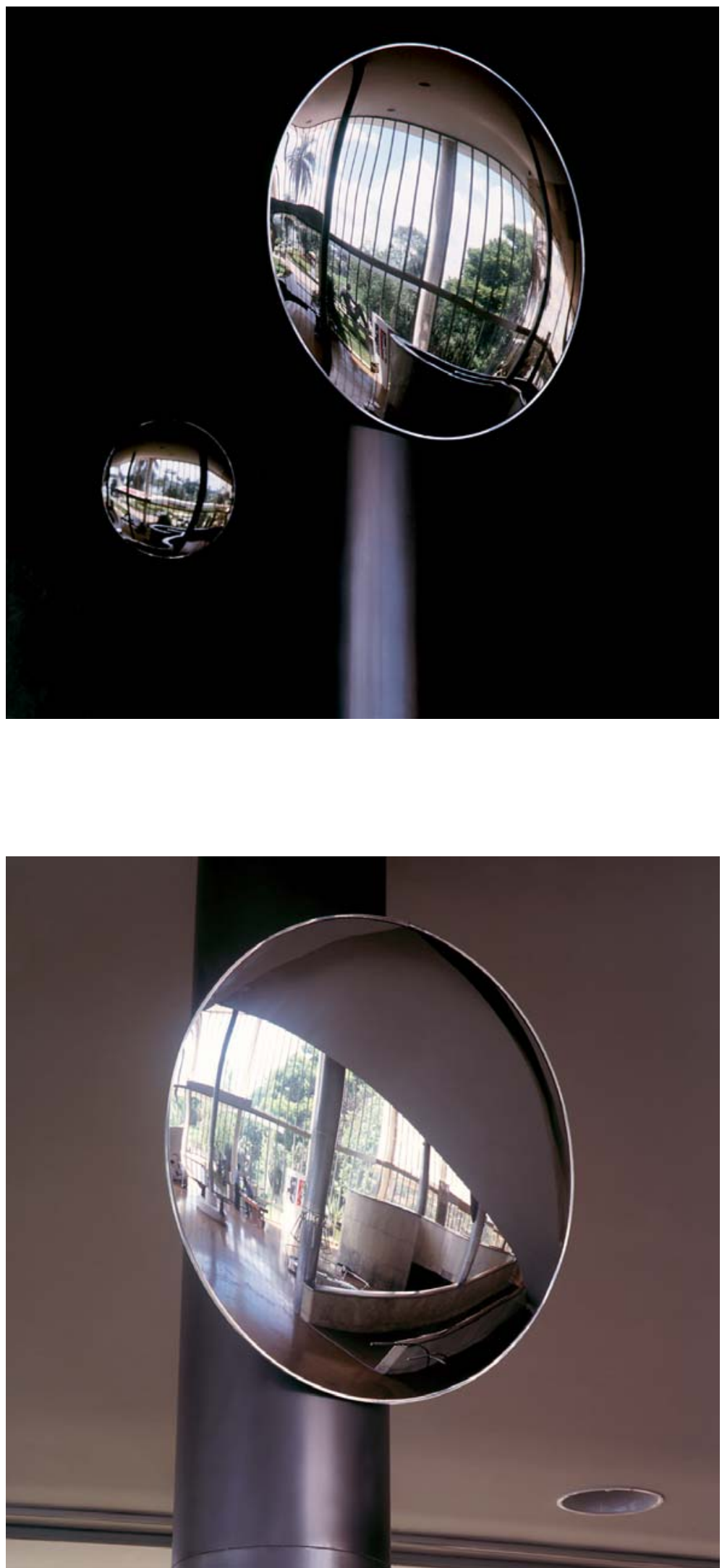

fig. 53 e 54 - "Coluna com retrovisor" (detalhes), 1997 


\subsubsection{A EXPERIÊNCIA DO NÃO-LUGAR}

"Porto Pampulha" radicalizava a experiência da utopia moderna ${ }^{65}$, implícita nesse projeto arquitetônico; pretendia ser um "meta-porto", onde as funções de lugar público de passagem nunca se efetivam definitivamente. Possibilitava a contemplação do belo — da paisagem e da arquitetura - ao mesmo tempo em que contextualizava o sujeito, através do movimento em "Amigo J9" e seu áudio, em um espaço de passagem, o "porto", cheio de implicações relativas à sua condição na vida contemporânea. Dessa forma, tinha também a intenção de simular a experiência da vida contemporânea a partir de uma visão crítica, proporcionada pela própria arte: o museu foi transformado em um não-lugar análogo aos não-lugares tal como conceituados pelo antropólogo Marc AuGé.

Para entender "Porto Pampulha" como um não-lugar e suas analogias com os não-lugares conceituados por Marc Augé, é importante agora remeter este corpo de considerações às contribuições feitas pela antropologia da atualidade a respeito dos significado dos espaços contemporâneos e sua relação com o indivíduo.

Focando seu campo de estudo nas relações entre o si-mesmo e o outro, entre espaço e alteridade, a antropologia da contemporaneidade reconhece no espaço presente o seu domínio. Para Pierre Lévy, um espaço antropológico seria:

um sistema de proximidade (espaço) próprio do mundo humano (antropológico), e portanto dependente de técnicas, de significações, da linguagem, da cultura, das convenções, das representações e das emoções humanas. ${ }^{66}$

Para ele ${ }^{67}$, podem-se caracterizar quatro tipos de espaços antropológicos. O

\footnotetext{
${ }^{65}$ Essa radicalização é alcançada através da musak usada como elemento do áudio: bossa nova, melodias típicas de lounge music dos anos '50 que, ouvidas hoje, nos remetem à uma época de euforia, glamour e sedução, característica dos anos em que a Pampulha foi construída. O carrinho elétrico, "Visita Guiada com Amigo J9. Para Edemar", é também elemento essencial para enfatizar o prazer da experiência estética inerentes à paisagem e ao ambiente do cassino. Ao dirigir o carrinho, o usuário assume, confortavelmente, o controle da "arte" e de sua experiência.

${ }^{66}$ LÉvy, Pierre. A Inteligência Coletiva: por uma Antropologia do Ciberespaço. São Paulo: Loyola. 1999, pp. 22 -23.

${ }^{67}$ Nesse parágrafo sintetizo as idéias de Pierre Lévy compreendidas entre as páginas 22 a 26 de A Inteligência Coletiva: Por uma Antropologia do Ciberespaço, cit.
} 
primeiro, a "terra nômade", que tem como modo de conhecimento os mitos e ritos, onde o indivíduo, ligado ao cosmo, constitui sua identidade a partir das relações de linhagem e vínculo estreito com a natureza. O segundo espaço, o "território", surge com a agricultura, a cidade, o Estado e a escrita; e seu modo de conhecimento estaria então relacionado ao desenvolvimento do saber "sistemático, teórico e hermenêutico". O homem passa a dominar a terra e a explorá-la e, ao contrário do homem nômade, seu vínculo não se refere mais à sua relação com o cosmo, mas com "uma entidade territorial". O terceiro espaço, que se desenvolveria então a partir do séc. XVI, seria o espaço das mercadorias que têm seu avanço com as viagens às Américas conquistadas pelos Europeus e que iria modelar um novo modo de conhecimento baseado nos fluxos econômicos — "fluxo de energias, de matérias-primas, mercadorias, capitais, mão-de-obra, informações" —, superando em velocidade a "terra" e o "território". Pierre Lévy propõe ainda um quarto espaço, o do saber, que relaciona a produção e distribuição do conhecimento com as novas tecnologias. Segundo ele "a informática comunicante se apresentaria então como a infraestrutura técnica do cérebro coletivo ou do hiper-córtex de comunidades vivas", cujo uso permitiria reunir "forças mentais a fim de constituir intelectuais ou 'imaginantes' coletivos" 68 .

Nesta breve descrição do que Pierre Lévy define como espaço antropológico, fica evidente que há muito a estruturação do espaço em que vivemos é decorrência direta das significativas mudanças de atitude do homem em relação ao seu contexto natural e esse contexto é, por sua vez, modelador de uma identidade cultural.

Com a palavra "espaço" designamos uma extensão, a distância entre duas coisas. O termo é uma abstração que hoje vem ganhando vários usos e aplicações: espaço do saber, espaço de lazer, espaço público, espaço

\footnotetext{
${ }^{68}$ Para Pierre LÉvy "o quarto espaço não existe, no sentido de que ainda não adquiriu sua autonomia. Mas em outro sentido, desde o advento de sua virtualidade, sua qualidade de ser é tal que seu grito ecoa na eternidade: o Espaço do saber sempre existiu". (...) Esse quarto espaço antropológico, caso venha a se desenvolver, acolherá formas de organização e de sociabilidade voltadas para a produção de subjetividades. Intelectuais coletivos caminharão nômades em busca de qualidades, modalidades de ser inéditas". Opus cit., p.122-123.
} 
publicitário, espaço aéreo, etc. Ao contexto no qual apreendemos essas noções Marc Augé chama "sobremodernidade". "Circulação, muros, gueto, subúrbio, fronteira: o vocabulário é naturalmente espacial em nossos dias, mas as palavras desse vocabulário têm tudo a ver com a relação entre o si-mesmo e o outro" ${ }^{69}$. Citando Michel de Certau, Marc Augé diz que "o espaço para ele [Michel de Certau] é 'um lugar praticado', 'um cruzamento de forças motrizes': são os passantes que transformam em espaço a rua geometricamente definida pelo urbanismo como lugar" 70 .

Fruto de uma vertiginosa aceleração de todos os fatores que caracterizam a época moderna, "a sobremodernidade ${ }^{71}$ surge quando a história se torna atualidade, o espaço se torna imagem e o indivíduo, olhar ${ }^{72}$. Segundo o autor, "a sobremodernidade dependeria de três imagens de excesso". A primeira delas, é o excesso de tempo ou a superabundância factual. A aceleração do tempo precipita a atualidade em fato histórico, o cotidiano se transforma rapidamente na história dos outros. A segunda imagem é a superabundância de espaço. Esta imagem diz respeito ao que AuGé define como "aquilo que paradoxalmente se deve chamar de estreitamento do planeta": as viagens virtuais, as comunicações em tempo real, a profusão de imagens mediatizadas que transforma nossa vivência de mundo em uma experiência de universos multiplicados, criando a ilusão de que todos somos um só. Por fim, a terceira imagem seria o excesso de individualismo, ou a individualização das referências, regidos pelo culto ao ego e pela ilusão de que se age e pensa individualmente.

\footnotetext{
${ }^{69}$ Augé, Marc. A Atualidade da Antropologia: o Sentido dos Outros. Rio de Janeiro: Vozes, 1999, pp. 133-4.

${ }^{70}$ Augé, Marc. Não-Lugares: Introdução a uma Antropologia da Supermodernidade. São Paulo: Papirus, 1994, p. 75.

${ }^{71}$ O termo original empregado por Marc AuGé é "surmodernité". Na versão para o português, optou-se pelo termo supermodernidade que, segundo o autor é uma escolha ruim "pois não se trata de uma 'hiper' ou de uma 'supermodernidade', mas antes de uma 'overmodernidade', a idéia da aceleração da história, dos acontecimentos, da afirmação individual, etc" (MIRAGLIA, Paula. "Agora Somos todos Contemporâneos: Entrevista com o Antropólogo Francês Marc Augé" in Sexta Feira: Antropologia, Artes e Humanidades. São Paulo: Pletora Ltda, n. 3, 1998, p. 114). Em respeito às intenções do autor, para uma maior fidelidade dos conceitos ao seu pensamento, optei pela substituição do termo supermodernidade por sobremodernidade (inclusive nas citações literais). Esse último, além de corresponder satisfatoriamente ao comentário de AuGé, funciona bem melhor em português que a alternativa que surge na entrevista — "overmodernidade" —, que é, do ponto de vista lingüístico, grosseira.

${ }^{72}$ Augé, Marc. A Atualidade da Antropologia: o Sentido dos Outros, cit., pp. 141-142.
} 
Marc AuGÉ coloca a sobremodernidade em contraste com a "modernidade baudelairiana" a fim de elucidar as diferenças entre essas duas referências de organização e percepção do espaço das cidades. Baudelaire demonstrava, em sua obra poética, grande sensibilidade e interesse pelas transformações que o mundo moderno impunha. Estas implicavam uma série de conflitos que colocavam em xeque os grandes sistemas simbolizados pelos marcos da cidade (a igreja, os monumentos...); no entanto tais marcos eram ainda reconhecidos e permaneciam carregados de sentido - “as chaminés, os campanários, esses mastros da cidade" 73 . Hoje não temos mais referenciais fixos que permanecem, muito menos uma estruturação orgânica que permita que o antigo se funda no atual, nem mesmo do modo problematizado que se observa em Baudelaire ${ }^{74}$.

Assim, na sobremodernidade, o passado não pode ser incorporado — só pode ser citado. Como diz Augé, "o que o espectador da modernidade contempla é a embricação (sic) do antigo e do novo. A sobremodernidade faz do antigo (da história) um espetáculo específico — como de todos os exotismos e particularismos locais. A história e o exotismo representam, aí, o mesmo papel que as "citações" no texto escrito"75.

No que se refere à experiência do espaço, a vida contemporânea é, para Marc AuGÉ, acima de tudo, produtora de não-lugares, aqueles que se opõem à noção do lugar antropológico e não se caracterizam como identitários, relacionais ou históricos:

A hipótese aqui defendida é a de que a sobremodernidade é produtora de não-

\footnotetext{
${ }^{73}$ Baudelaire, Charles. Apud Augé, Marc. Não-Lugares: Introdução a uma Antropologia da Supermodernidade, cit., p. 72 .

${ }^{74}$ Como diz Marshall Berman, "Por vários motivos, o modernismo das cenas modernas primordiais de Baudelaire é notavelmente fresco e contemporâneo. Por outro lado, sua rua e seu espírito parecem confrangedoramente arcaicos. Não porque nosso tempo tenha resolvido os conflitos que conferem vida e energia a Spleen de Paris — conflitos ideológicos e de classe, conflitos emocionais entre pessoas íntimas, conflitos entre o indivíduo e as forças sociais, conflitos espirituais dentro do indivíduo - , mas, antes, porque nosso tempo encontrou novos meios de mascarar e mistificar conflitos. Uma das grandes diferenças entre os séculos XIX e XX é que o nosso criou toda uma rede de novos halos para substituir aqueles de que o século de Baudelaire e Marx se desfez" (BERMAN, Marshall. Tudo que é Sólido Desmancha no Ar: A Aventura da Modernidade. São Paulo: Companhia das Letras, 1986, p. 159).

${ }^{75}$ Augé, Marc. Não-Lugares: Introdução a uma Antropologia da Supermodernidade, cit., p. 101.
} 
lugares, isto é, de espaços que não são em si lugares antropológicos e que, contrariamente à modernidade baudelairiana não integram os lugares antigos: estes, repertoriados, classificados e promovidos a "lugares de memória", ocupam aí um lugar específico e circunscrito. Um mundo onde se nasce numa clínica e se morre num hospital, onde se multiplicam, em modalidades luxuosas ou desumanas, os pontos de trânsito e as ocupações provisórias (as cadeias de hotéis e os terrenos invadidos, os clubes de férias, os acampamentos de refugiados...), onde se desenvolve uma rede cerrada de meios de transporte que são também espaços habitados onde o frequentador das grandes superfícies, das máquinas automáticas e dos cartões de crédito renovado com os gestos do comércio "em surdina", um mundo assim prometido à individualidade solitária, à passagem, ao provisório e ao efêmero, propõe ao antroplólogo, como aos outros, um objeto novo cujas dimensões inéditas convém calcular antes de se perguntar a que olhar ele está sujeito. ${ }^{76}$

Os não-lugares são regulados pela mediação: textos, senhas, prospectos informativos e instruções que orientam o indivíduo e, contrariamente aos "lugares antropológicos que criam um social orgânico, os não-lugares criam uma tensão solitária"77. A sua principal característica é a "indiferença": são espaços de permanência provisória, de rotatividade, onde as necessidades dos indivíduos é suprida de maneira mais rápida e eficiente. Neste contexto talvez faça sentido a expressão "pegue-pague". Da mesma forma em que o lugar é indiferente ao indivíduo, este também o é em relação ao lugar. As relações que se estabelecem são efêmeras e o indivíduo se transforma em passageiro, usuário em trânsito:

por fim o usuário dos não-lugares, reduzidos à sua função de passageiro de consumidor ou de utilizador, experimenta uma forma particular de solidão. Definido por seu destino, a soma de suas compras ou a situação de seu crédito, o usuário dos não lugares anda ao lado de milhões de outras pessoas, mas está só e são os textos (painéis, discos, vídeos) que se interpõem entre ele e o mundo exterior. $O$ paradoxo da sobremodernidade acha-se, então, no seu auge: nos não-lugares a pessoa não se sente em casa, mas não se está nunca com os outros. ${ }^{78}$

Em consonância com essas noções é que "Porto Pampulha" foi projetada. A exposição privilegiava o deslocamento do sujeito para submetê-lo a uma

${ }^{76}$ Idem, pp. 73-74. O itálico é meu.

77 Idem, pp. 87.

${ }^{78}$ AuGÉ, Marc. A Atualidade da Antropologia: O Sentido dos Outros, cit., p.144. 
experiência crítica dentro do espaço-tempo da arte, fazendo com que ele se percebesse ocupando, simultaneamente, a posição do usuário do não-lugare da arte. A experiência solitária do carrinho elétrico "Amigo J9" e do museu transformado em "porto", proporcionava o deslocamento para um outro nãolugar —o aeroporto- e na mistura dessas múltiplas paisagens é que se dava a experiência da obra. 


\subsubsection{A EXPERIÊNCIA DO SITE AO SITE-SPECIFIC DESLOCADO}

Na exposição "Relax'o'visions", realizada no MuBE - Museu Brasileiro da Escultura, em São Paulo, um ano após "Porto Pampulha", as questões até agora apresentadas alcançaram um novo patamar de complexidade. Em ambas exposições a consideração dos significados inerentes ao site foi essencial. A diferença drástica da primeira para a segunda é decorrente da própria natureza do lugar onde cada uma foi instalada. A exposição no MuBE toma partido do fato de que esse espaço, que foi especialmente projetado e construído para ser um museu, é um site especializado. É importante então voltar às reflexões de Foucault a respeito do site e da rede de sites, para examinar como se constituem os sites que se especializam em arte.

Também no campo da arte a modernidade construiu seu espaço especializado e formou sua rede (museus, galerias, bienais, feiras de arte, escolas) permitindo o desenvolvimento das especificidades das linguagens, para as quais o espaço da galeria, que foi denominado "cubo branco", servia de suporte. Esse espaço neutro, livre de impurezas e dos ruídos do mundo, que tratou de eliminar de seu contexto todas as contaminações da vida, passou a abrigar o pensamento especializado da arte. Segundo descreve Brian O'DOHERTY a respeito do "cubo branco", "o mundo externo não deve entrar, então as janelas são trancadas. Paredes são pintadas de branco. O teto se transforma na fonte de luz... A arte é liberada, como se costuma dizer, para assumir sua própria vida" 79 . Através de sua neutralidade, o contexto da arte é silenciado da mesma forma em que a pintura modernista elimina a malha perspectivada em favor de uma malha quadriculada: "a malha [quadriculada] anuncia, entre outras coisas, a vontade do silêncio da arte moderna, sua hostilidade em relação à literatura, à narração e ao discurso" 80 .

\footnotetext{
${ }^{79}$ O'DOHerTY, Brian. Opus cit., p. 15.

${ }^{80}$ Krauss, Rosalind E. "Grids" in The Originality of the Avant-Garde and Other Modernist Myths. Cambridge: The MIT Press, 1988, pp. 8-22.
} 
Como seria possível então um espaço idealizado, neutralizado pela exclusão das "contaminações" da vida, permanecer na rede, uma vez que a condição básica para tanto seria a inter-relação e a interdependência em relação a outros sites? Pois bem, não é possível, e essa contradição é interna à proposta do "cubo branco". Para entendê-la é preciso retornar a Foucault, que nos permitirá, através do conceito de heterotopia de compensação, uma compreensão mais ampliada do "cubo branco" no contexto da contemporaneidade. Segundo esse autor,

as heterotopias têm uma função em relação a todo o espaço restante. Essa função se desdobra entre dois pólos extremos. Ou seu papel é criar um espaço de ilusão que expõe cada espaço real, todos os sites nos quais a vida humana se particiona, como ainda mais ilusórios (...). Ou então, ao contrário, seu papel é criar um espaço que é outro, um outro espaço real, tão perfeito, tão meticuloso, tão bem arrumado quanto o nosso é bagunçado, equivocadamente construído ${ }^{81}$ e confuso. Esse último tipo seria a heterotopia, não de ilusão, mas de compensação. ${ }^{82}$

E é essa compensação que talvez o "cubo branco" tenha se encarregado de criar e sustentar — um mundo mais-que-perfeito (o da arte) para nos compensar de tudo que perdemos na desordem geral.

De um modo geral, a ideologia implícita no "cubo branco" resistiu até os anos cinqüenta e sessenta quando, provavelmente,

a maioria dos artistas americanos não tinha a consciência de que eles próprios não controlavam sua arte, que suas produções poderiam ser usadas não apenas para o prazer estético ou decoração ou como um símbolo de status, mas como uma arma educativa. ${ }^{83}$

É aproximadamente no final dos anos sessenta que se instaura a crise que vai colocar em xeque o rígido sistema que por tanto tempo regulou a arte. A obra deixa de ser pensada apenas como um objeto; surgem então os happenings, as

${ }^{81}$ No original, "ill-constructed".

${ }^{82}$ Foucault, Michel. Opus cit., p. 243. Os itálicos são meus.

${ }^{83}$ LIPPARD, Lucy R. "The Pink Glass Swan: Upward and downward mobility in the art world" in The Pink Glass Swan: Selected Feminist Essays on Art. New York: The New Press, 1995, p. 118. 
performances, a body $\operatorname{art}^{84}$, as instalações e os site-specifics ${ }^{85}$, manifestações nas quais se enfatiza a relação espaço-temporal, e a obra passa a se constituir como ação e intervenção efêmera. Há, nessas formas de atuação, uma intenção política, que implica, além de outras coisas, uma tentativa de democratizar a $\operatorname{arte}^{86}$. O trecho que segue é um pequeno relato da resposta que a arte pôde dar à contradição implícita na idéia de "cubo branco", desde a perspectiva da concepção moderna de espaço.

Nos anos sessenta, a luta pelas grandes transformações sociais se espalha pelo mundo afora. Os movimentos organizados em defesa da liberdade, dos direitos humanos —em defesa da mulher, do negro e outras minorias- favorece um posicionamento crítico do artista. Em "Farewell to Modernism", Kim LeviN afirma que "até os anos sessenta, com a arte Pop abraçando os processos e os produtos da produção em massa e o minimalismo adotando os materiais e métodos da indústria, já havia chegado a década final da tecnologia" ${ }^{87}$. É claro que os anos sessenta não representaram a culminação da tecnologia; mesmo assim, como relata a autora, a associação da arte às investigações tecnológicas causava então a impressão de estar concretizando o sonho modernista baseado no progresso. Porém, rapidamente, a euforia resultante de uma visão otimista é substituída pela consciência de uma falência das instituições, assinalada pelo

\footnotetext{
${ }^{84}$ Para um aprofundamento a respeito dos happenings, performances e body art ver: (1) BATTOCK, G. \& NICKAS, R. The Art of Performance A Critical Anthology. New York: E.P. Dutton, Inc., 1984. (2) Henrl, Adrian. Total Art: Environments, Happenings and Performances. New York: Oxford University Press, 1974. (3) Mc EVILLEY, Thomas. "Art in The Dark" in HeRTZ, Richard. (org.) Theories of Contemporary Art. New Jersey: Englewood Cliffs, Prentice-Hall, INC., 1985, pp 287-305. (4) JONES, Amelia. Body Art: Performing the Subject. Minneapolis: University of Minnesota Press, 1998.

${ }^{85}$ Para instalações e site-specific ver: (1) Krauss, Rosalind. "Sculpture in the Expanded Field" in HerTz, Richard. (org). Theories of Contemporary Art. New Jersey: Englewood Cliffs, Prentice-Hall, Inc., 1985, pp. 215-224. (2) CRIMP, Douglas (with photographs by LAwLER, Louise) On The Museum's Ruins. Cambridge, Massachusetts: The MIT Press, 1993. (3) Oliveira, N., Oxley, N., Petry, M. Installation Art. London: Thames and Hudson, 1996.

86 "A arte conceitual [entre 1967 e 1971] parecia politicamente viável por causa da noção implícita de que o uso de meios comuns, baratos e não volumosos levaria a um tipo de socialização (ou pelo menos democratização) da arte em contraposição à telas gigantes e esculturas cromadas enormes custando cinco dígitos e enchendo o mundo com mais fetiches de consumidor". LiPPARD, Lucy. The Pink Glass Swan: Selected Feminist Essays on Art. New York: The New Press, 1995, p. 121.

${ }^{87}$ LeVIN, Kim. "Farewell to Modernism" in HeRTZ, Richard (org.) Theories of Contemporary Art. New Jersey: PrenticeHall, 1985, pp.01-09.
} 
cenário da Guerra do Vietnã que invadia os lares via televisão, por Woodstock, pelas marchas pela paz, pelas conflitos raciais, pelo movimento feminista, demonstrações e violências. Reflexões puramente formais e "otimistas" bem como os formatos tradicionais de produção foram então substituídos pela busca de um redimensionamento, não só da arte enquanto objeto/processo/atividade, mas também do sistema onde é inserida. A produção artística passou a investir no retorno à natureza (Ana Mendieta, Richard Long, James Turrell), nos materiais em estado natural (Arte Povera na Europa), no deslocamento da arte para a paisagem do campo (Mary Miss, Nancy Holt, Michel Heizer, Walter de Maria, Robert Smithson), ou em uma produção focada nos limites do próprio corpo (Carolee Schneemann, Ligia Clark, Vito Aconcci, Hélio Oiticica) dando origem a um tipo de pensamento fundado em uma tomada de posição política em relação às instituições, em todos os níveis. Para LEvIN,

1968 talvez tenha sido o ano crucial, o ano em que paramos de querer olhar para a arte como conhecíamos, quando até mesmo a mais pura forma começava a parecer supérflua, e nos demos conta de que apenas inovações tecnológicas não eram mais suficientes. ${ }^{88}$

A autora sugere que 1969 marcaria o final da era modernista, com a revelação da obra "Étant Donnés" de Marcel Duchamp,

com toda sua impureza híbrida, teatralidade ilusionística, insinuações narrativas e contradições contra-revolucionárias - abrindo um olho mágico para um mundo natural mágico, como se prevendo preocupações pós-modernistas. ${ }^{89}$

Os happenings, as performances, a body-art, as instalações e, finalmente, os site-specific abriram o caminho para que a atuação artística migrasse para espaços além do território especializado da arte e para que as reflexões extrapolassem seu próprio domínio. Através dessas experiências, o "cubo branco" passou a ser problematizado. A crítica às instituições, gerada a partir de então, fez com que os espaços especializados, antes tidos como o contexto privilegiado da arte, fossem perdendo sua suposta neutralidade. Dessa forma,

\footnotetext{
${ }^{88}$ Idem, pp. 02-03.

${ }^{89}$ Idem, p. 03.
} 
o isolamento do "cubo-branco" na rede é confrontado pela constante tentativa de reintegração da arte. Tal reintegração é alcançada apenas quando a arte provoca reverberações na consciência do sujeito, revertendo os pressupostos por ele assimilados, não só relativos ao sistema da arte, mas também ao social e político, bem como à posição que esse sujeito ocupa dentro desses sistemas. Os espaços da arte são forçados a abrir suas portas para se "contaminar de vida", deixando assim de ser "utopia efetivamente atuada", ou seja, deixando de ser "cubo-branco". Mesmo assim, a herança do "cubo-branco" permanece.

Tendo em vista essas considerações sobre a história da arte recente, passo agora a avaliar as características arquitetônicas do Museu Brasileiro da Escultura incorporadas na concepção da exposição "Relax'o'visions" ${ }^{\prime \prime 90}$, realizada ali em 1998.

A adequação da planta do museu ao terreno, localizado na esquina da Rua Alemanha com a Av. Europa, procurou privilegiar as características relativas ao seu desenho, à sua topografia, aos lençóis freáticos existentes. Como resultado temos uma interessante articulação entre os vários planos que organizam o espaço externo e constituem a área interna, nomeada de Grande Galeria —um abrigo subterrâneo sem contato com a paisagem local. Tanto o espaço externo quanto a galeria interna têm sido apenas esporadicamente utilizados para exposições de $\operatorname{arte}^{91}$. Separados um do outro, são espaços

\footnotetext{
${ }^{90}$ O projeto de construção do museu, iniciado em 1987 e concluído em 1995, é de autoria de Paulo Mendes da Rocha. Foi idealizado para ser "museu de escultura, pinacoteca e ecologia" (Rocha, Paulo Mendes da. "Arquitetura Modelando a paisagem" in Projeto: Revista Mensal de Arquitetura, Desenho, Planejamento Urbano e Construção. Março, 1995) e, antes mesmo da inauguração, foi destinado a abrigar somente o museu da escultura.

${ }^{91}$ Para a tristeza geral da comunidade artística de São Paulo, o MuBE foi apelidado de Museu Brasileiro de Eventos! Foram poucas as exposições de arte realizadas desde sua inauguração: em nenhum momento o museu apresentou uma programação contínua, coerente e significativa, com exceção do período em que foi dirigido por Fábio Magalhães e Inês Raphaelian. Sua política administrativa, desde a implantação, tem sido controlada pela fundadora, a Sra. Mariliza Ratzan (senhora da sociedade paulistana que decidiu lutar para a construção de um museu em área nobre da cidade, com o objetivo de oferecê-lo à população como um patrimônio cultural). Pois bem, apesar de sua "luta" para a concretização desse nobre projeto, a Sra. Ratsan tem cometido equívocos gravíssimos e aumentado, a cada ano que passa, sua dívida com os cidadãos paulistanos e com a arte brasileira em geral. Por total falta de uma administração profissional e de um staff especializado na área museológica e curatorial, bem como de um projeto cultural definido, essa senhora transformou esse excelente espaço de arte, que conta com projeto arquitetônico internacionalmente reconhecido, em buffet para eventos de marketing da elite empresarial da cidade. Ora, sabemos
} 
autônomos, com comunicação que serve somente ao tráfego dos visitantes. A experiência simultânea dos espaços interno e externo não é favorecida pela orientação do projeto arquitetônico. Isolada do espaço da cidade, a galeria subterrânea não oferece vistas nem permite o acesso direto para seu exterior. Os extensos paredões em concreto encaminham o visitante para um interior protegido e abrigado. Aí reside o aspecto mais curioso desse espaço especificamente projetado como museu de arte: é fácil perceber a maneira como a arquitetura da Grande Galeria incorpora, de modo notável, as idéias implícitas no conceito de "cubo branco". É isolada, não tem janelas ou comunicação com o exterior e sua localização subterrânea e protegida remete, inevitavelmente, às casamatas, cuja função poderia ser a de salvaguardar a arte do espaço da vida. Aí a noção de espaço-tempo real é substituída pela experiência atemporal de seu interior. Essas são, certamente, as características básicas que nortearam a análise espacial que deu origem a "Relax'o'visions" e à concepção do sitespecific deslocado.
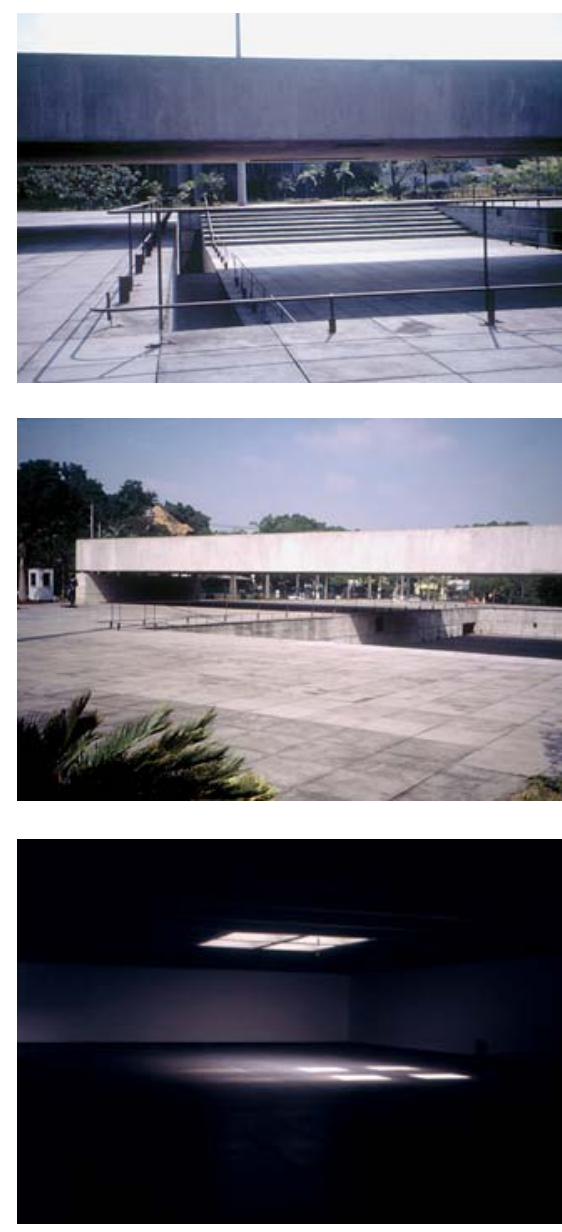

fig. 55 e 56 - MuBE (vista externa) fig. 57 - MuBE (Grande Galeria), SP

Em contraposição à experiência do não-lugar proporcionada em "Porto Pampulha", associada à contemplação do belo —da paisagem e da

que a condição financeira das instituições de arte no Brasil é precária, e conta, em grande parte, com o trabalho voluntário de excelentes profissionais e, mesmo assim, o profissionalismo nessa área tem se revelado de alto nível. A arquitetura do MuBE vem sendo depredada, com autorização indevida para alteração do projeto arquitetônico (como o recente corte do paredão externo que delimita o corredor para acesso à Grande Galeria, feita pela empresa que arrenda o restaurante com o objetivo de "abrir uma janela para que os clientes vejam a paisagem!") e pelo uso inapropriado de seu espaço, que serve como palco para festas e eventos efêmeros.

É curioso fazer um paralelo entre as origens dos projetos do Cassino da Pampulha e do Museu da Escultura. Ambos são instituições de arte. A primeira, cujo projeto se destinava a ser um cassino, perdeu sua função seis anos após a inauguração, devido ao decreto que proibia o jogo no Brasil. É hoje museu de arte, contaminado pelos significados de seu passado, por sua história e pela condição renovada de seu contexto turístico. O segundo, construído para ser museu, permanece sem história. É um marco arquitetônico vazio, que flagra a política muitas vezes 'doméstica', ainda presente no cenário cultural da cidade. Ironicamente, o museu associado aos ideais do "cubo branco" está abandonado, desprovido de suas funções originais. 
arquitetura-, a experiência do não-lugar em "Relax'o'visions" estava fundada na impossibilidade da experiência do espaço e tempo reais, pois uma vez que a arquitetura é subterrânea, o visitante não tem acesso ao contexto externo.

O título da exposição, "Relax'o'visions", se afirma como uma sugestão irônica das paisagens relaxantes que com certeza não estão presentes na exposição —remete ao desejo do indivíduo contemporâneo de "escapar" das condições estressantes da vida na contemporaneidade.

Escapar para onde? Ao descer a rampa de acesso principal à Grande Galeria o visitante estará diante de uma paisagem em abismo. Uma "Parede Niemeyer"192, constituída por módulos de espelho, duplica o interior do espaço, alterando radicalmente a percepção da arquitetura de Paulo Mendes da Rocha. "Colunas Niemeyer" são estrategicamente posicionadas. Colunas múltiplas reforçam o efeito multiplicador do espelho. O caminho sugerido pela rampa leva ao espelho. Todo entorno é capturado e duplicado na superfície espelhada que transforma o espaço interno em infinito. Colunas, espelhos retrovisores, bancos sofás, alças, catraca e um som ambiente transformam o espaço "neutro" da arquitetura de filiação modernista, o "cubo-branco", em um não-lugar, para propiciar uma experiência crítica no interior do espaço da arte. Aqui a noção de "flagrar" tem conotação espelhada. Uma arquitetura flagra a outra. Ao reproduzir as colunas e a parede de espelho próprias da arquitetura do Cassino da Pampulha e denominá-las "Parede Niemeyer" e "Colunas Niemeyer", a exposição passa a revelar a contaminação de uma arquitetura na outra. Teremos assim em "Relax'o'visions" um site-specific sendo deslocado para outro:

92 O projeto original da obra "Exit" (1999), que chamava-se "Exit com Parede Niemeyer", incluía também a instalação de uma parede

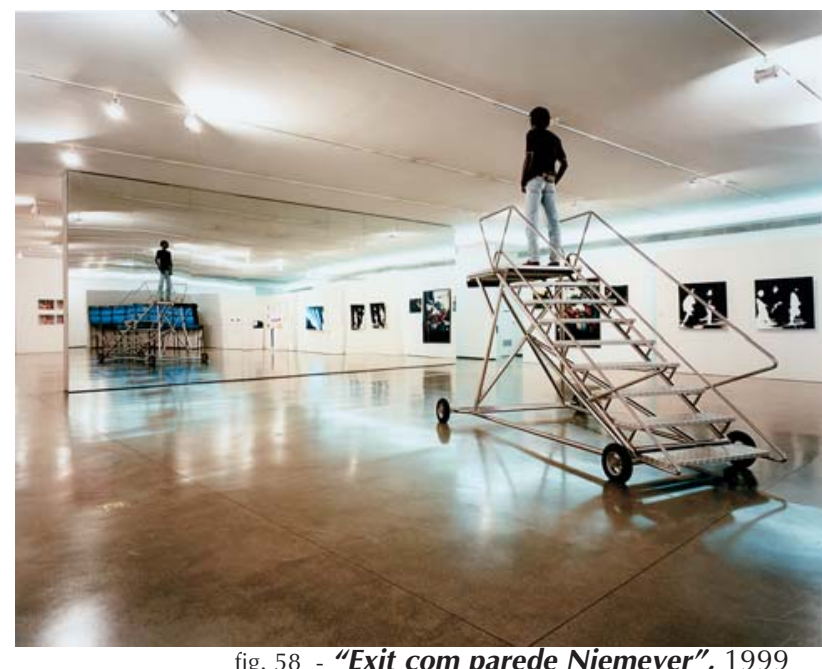
modulada de espelhos intitulada "Parede Niemeyer". Ela remete à experiência de espelhamento tratada nas exposições "Porto Pampulha" e "Relax'o'visions". Esta versão (a original) só pôde ser realizada por ocasião da exposição itinerante "Panorama 99", no Museu de Arte Moderna de São Paulo, em outubro de 1999 e no Museu de Arte 


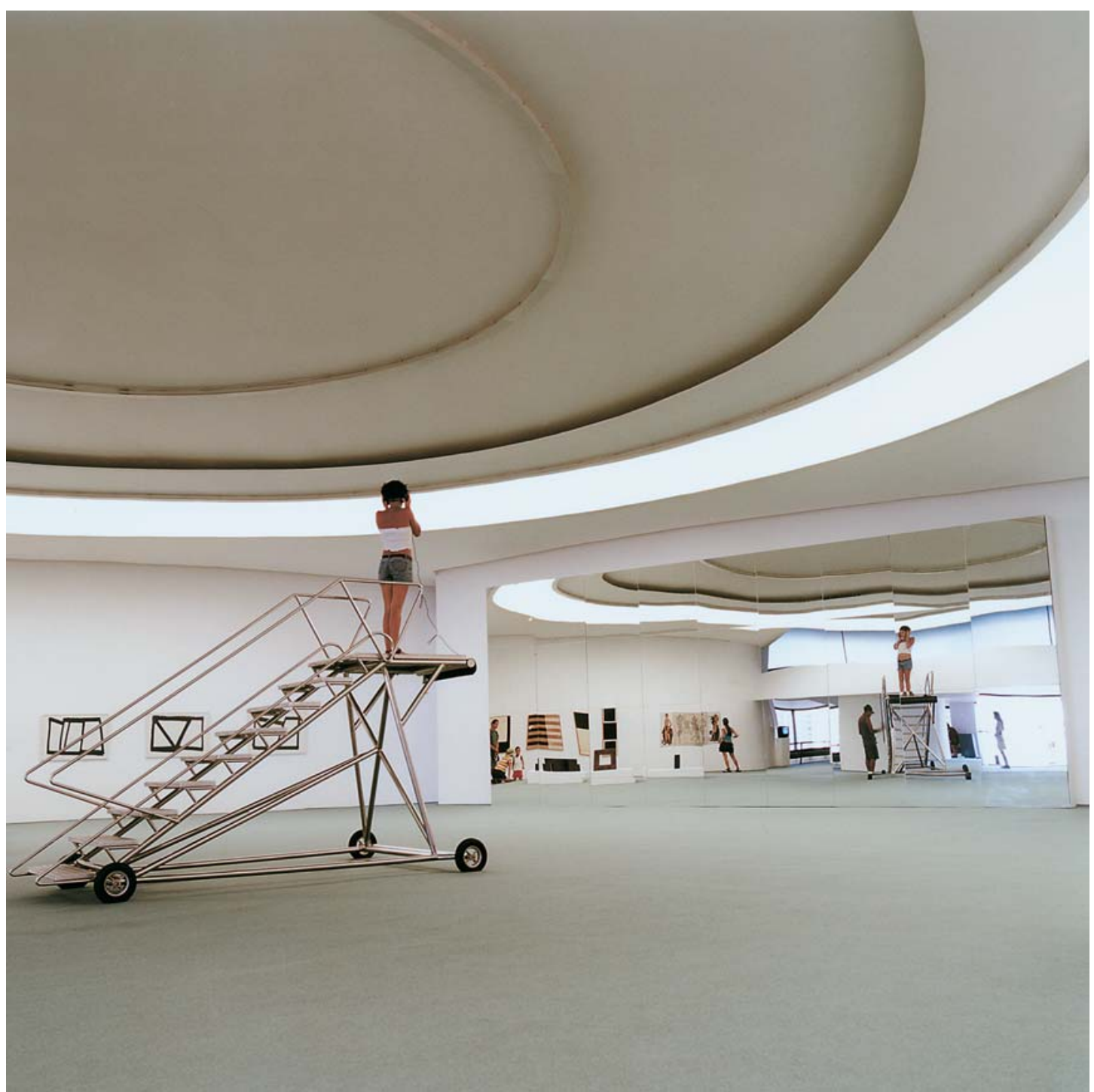

fig. 59 - "Exit com parede Niemeyer", 1999 
Niemeyer passa a abrigar Paulo Mendes da Rocha e vice-versa. Nesse encontro ambas arquiteturas se deslocam e ganham novos significados. Assim tem origem o site-specific deslocado.

No contexto da produção artística depois dos anos sessenta, o emprego do termo site passou a incluir a idéia de um "lugar particular ou localização no mundo como um todo". É essa a definição de Robert Smithson, artista que também formulou a contrapartida dessa idéia e se encarregou de denominá-la de nonsite: "uma representação na galeria daquele lugar na forma de material transportado, fotografias, mapas e documentação relacionada" ${ }^{93}$. Como se vê, o deslocamento do site proposto por Smithson é de outra natureza. Ele se refere a uma de representação do site, em forma de documentação ou mesmo uma espécie de mostruário dos elementos particulares do site que seriam movidos de seus locais originários, reorganizados e transformados em obras para o contexto da galeria. Nesse deslocamento, a identidade primeira de cada um dos sites é preservada, pois não há uma fusão ou integração das partes. Aí reside a diferença básica entre o nonsite de Robert Smithson e o que optei por denominar site-specific deslocado. No caso de "Relax'o'visions" as arquiteturas de Niemeyer e Paulo Mendes da Rocha se transformam em um não-lugar único, ampliando o conflito do sujeito.

Em "Relax'o'visions" o conflito do sujeito se expande pois o deslocamento se multiplica. Não são apenas os equipamentos do mobiliário urbano que foram deslocados para o interior do site especializado em arte, como na exposição "Rotatórias", em 1996. Aqui o espaço da Grande Galeria do MuBE incorporou de vez o caráter das galerias subterrâneas — das estações de metrô. Através da multiplicação dos elementos constituintes do espaço e do som ambiente

\footnotetext{
Contemporânea de Niterói, em dezembro do mesmo ano.

${ }^{93}$ Oliveira, N., Oxley, N., Petry, M. Installation Art. London: Thames and Hudson, 1996. p. 33. Convém distinguir o termo nonsite de Smithson e os não-lugar de Marc AuGÉ. O primeiro diz respeito à relação entre a experiência no espaço-tempo real, concretizada no site e traduzida em forma de espaço-tempo representado, para ser inserida no contexto da galeria. O segundo refere-se aos espaços de passagem da vida contemporânea, onde a relação com o indivíduo está baseada na indiferença: o lugar é indiferente ao sujeito e o sujeito é indiferente ao lugar. É, por natureza, o oposto da noção de lugar antropológico que AuGÉ caracteriza como "identitário, relacional ou histórico", como já vimos.
} 
que aludia aos aeroportos caracterizados pelo tráfego intenso de pessoas e de aviões, a experiência de espelhamento favorecia uma espécie de deslocamento espaço-temporal em conflito: não se sabia mais se era passado ou futuro, restando então ao sujeito o esforço do posicionamento. 


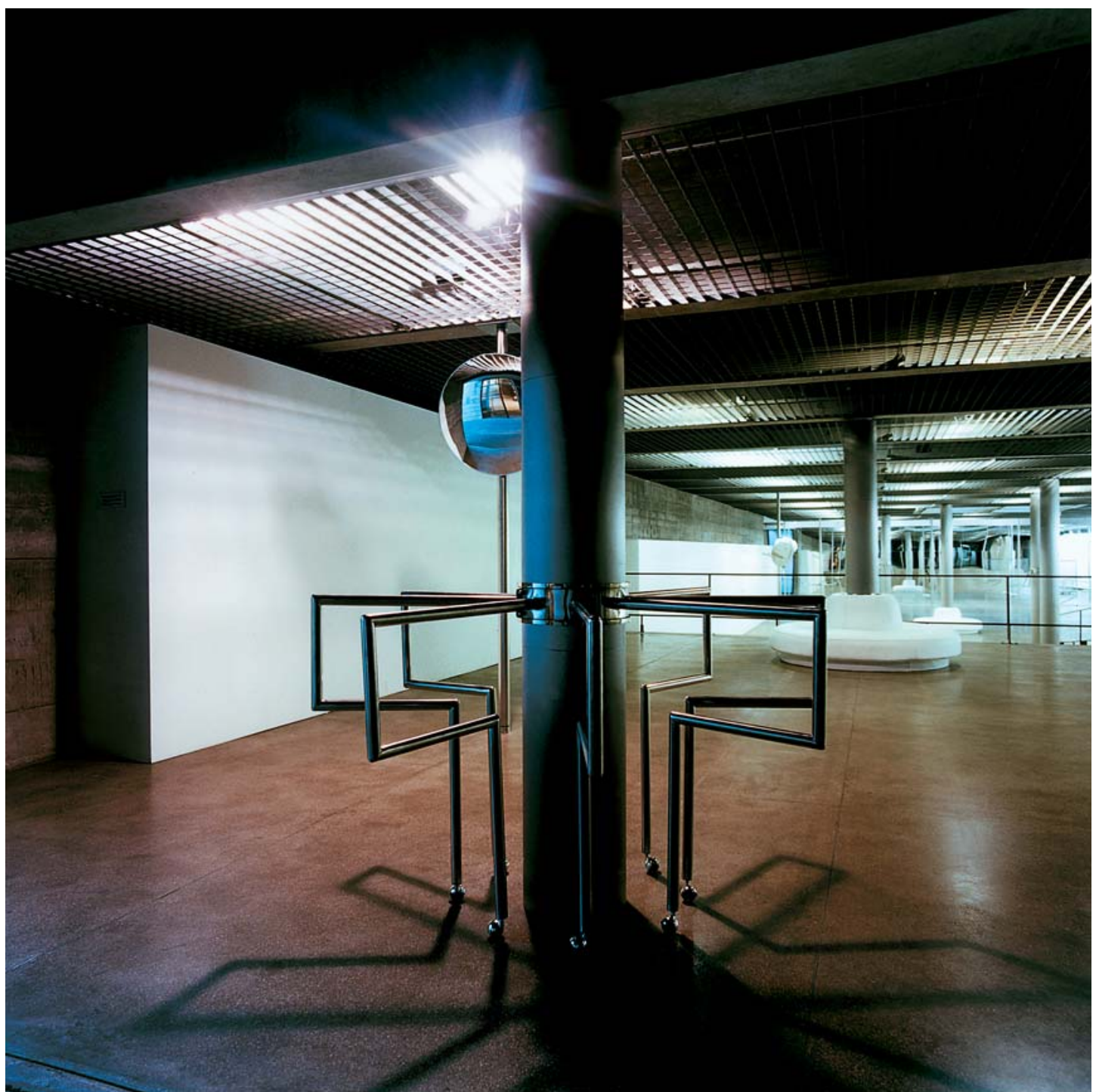

fig. 60 - "Coluna Niemeyer com catraca", 1998 


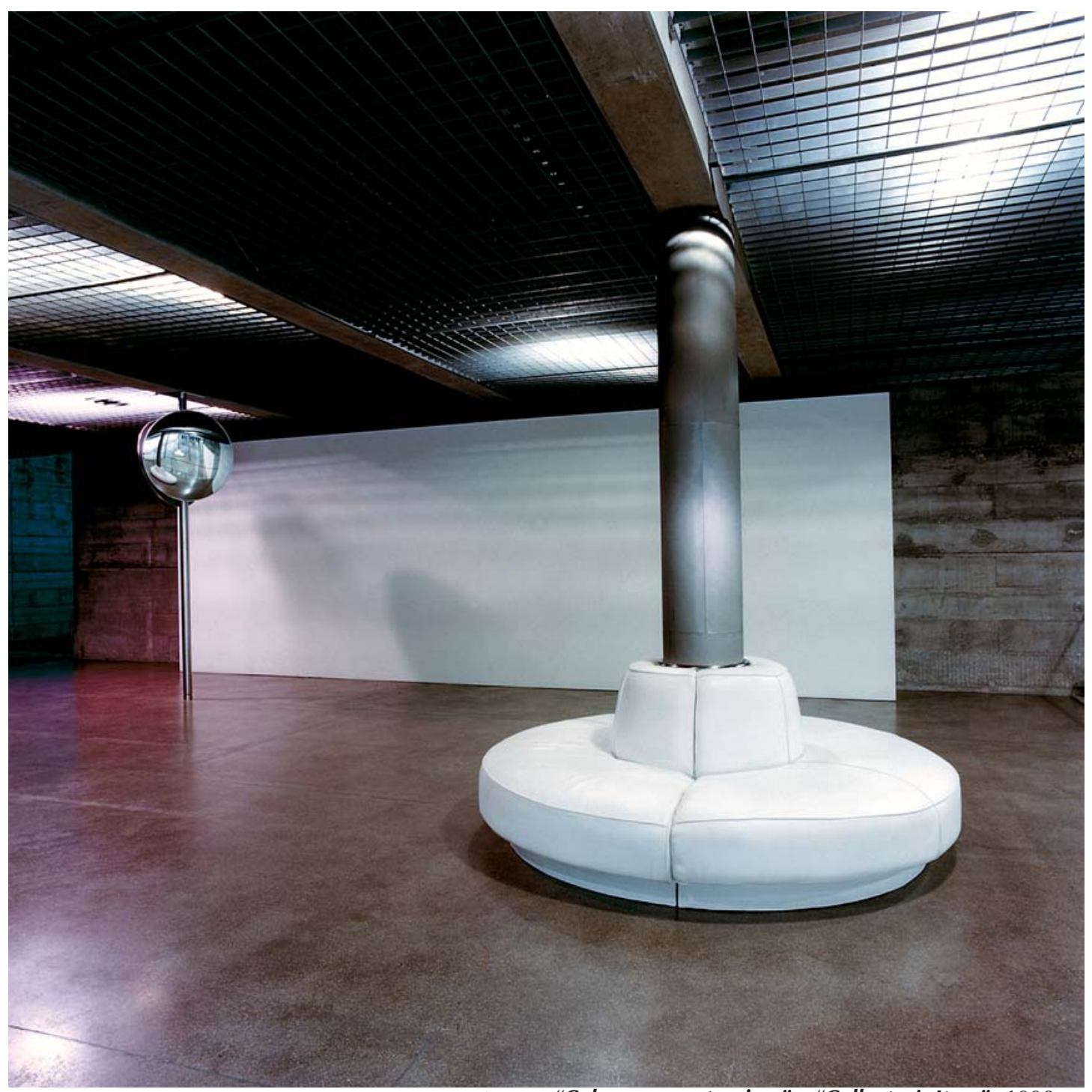

fig. 61 - "Coluna com retrovisor" e "Collector's Item", 1998 


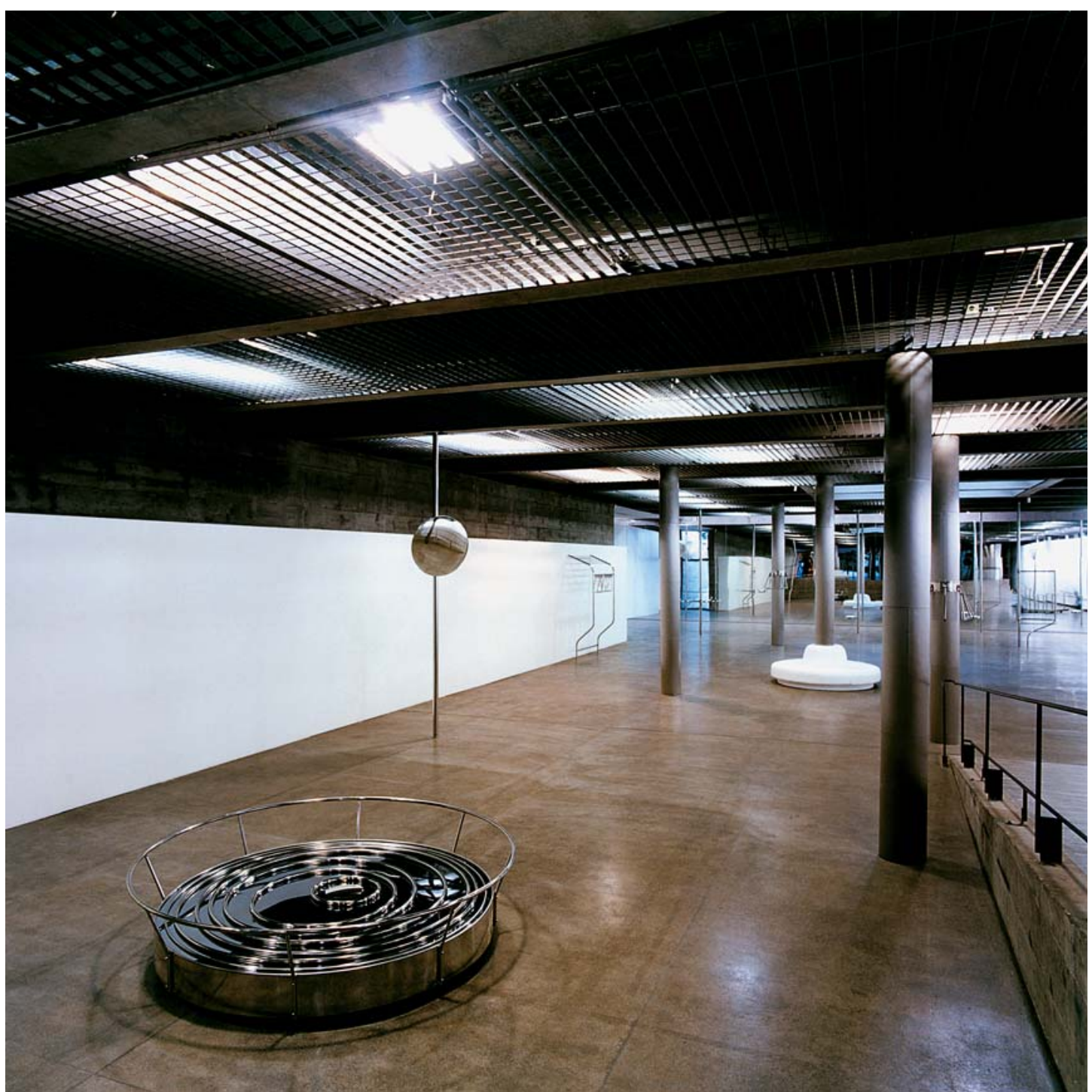

fig. 62 - "Relax'óvisions", 1998 (vista parcial) 


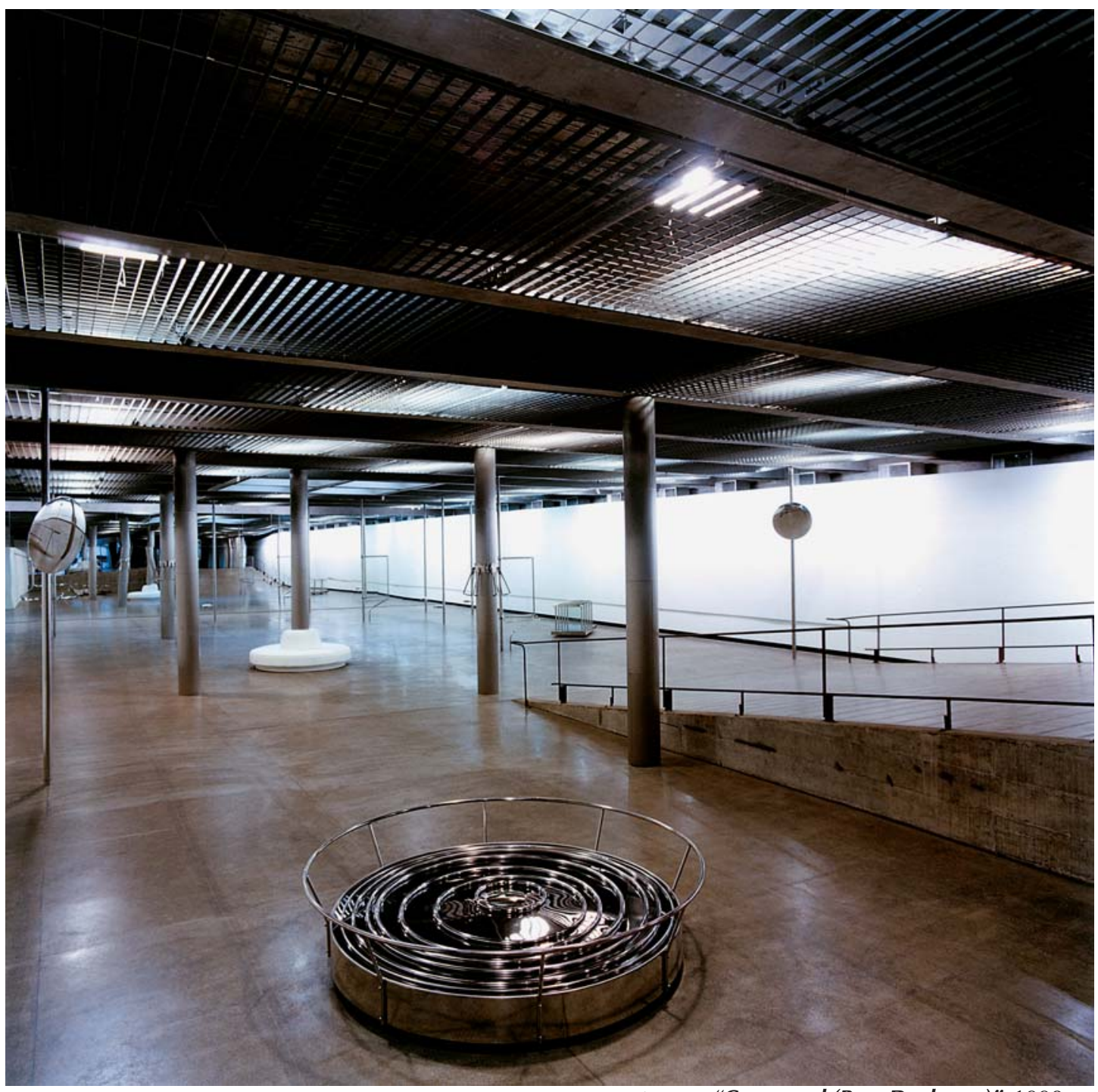

fig. 63 - "Carroussel (Para Duchamp)", 1998 


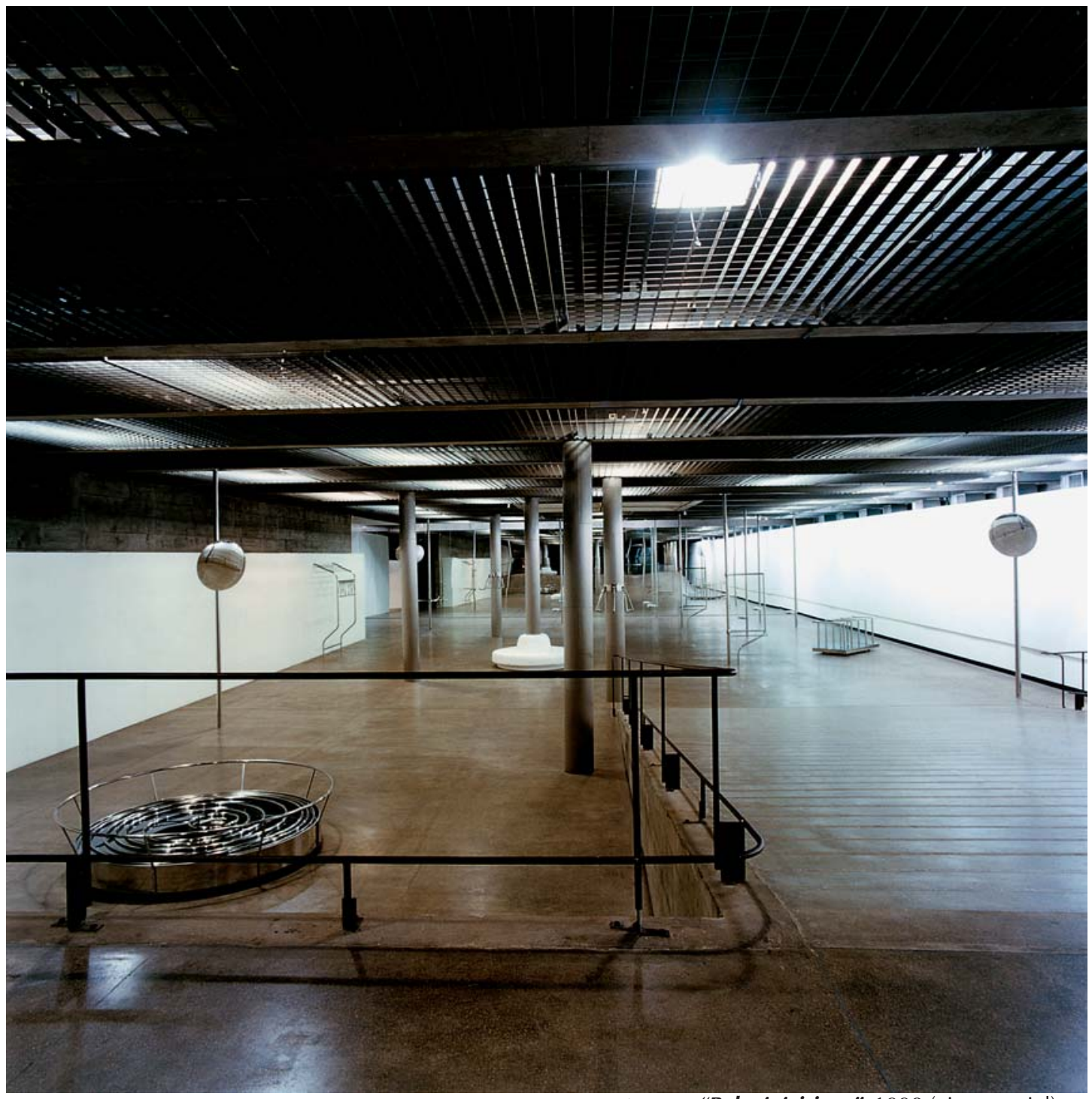

fig. 64 - "Relax'o'visions", 1998 (vista parcial) 


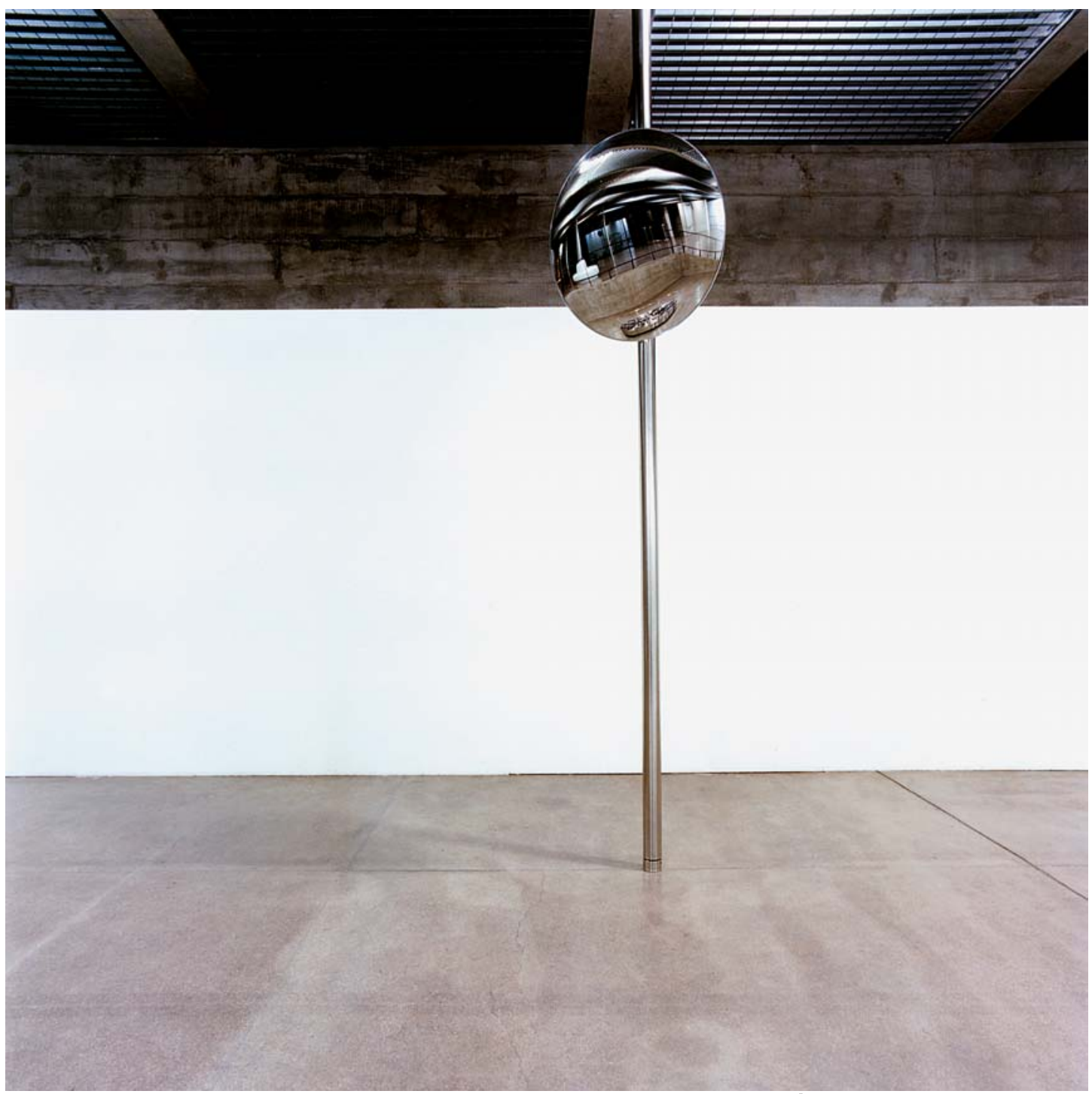

fig. 65 - "Coluna com retrovisor", 1998 


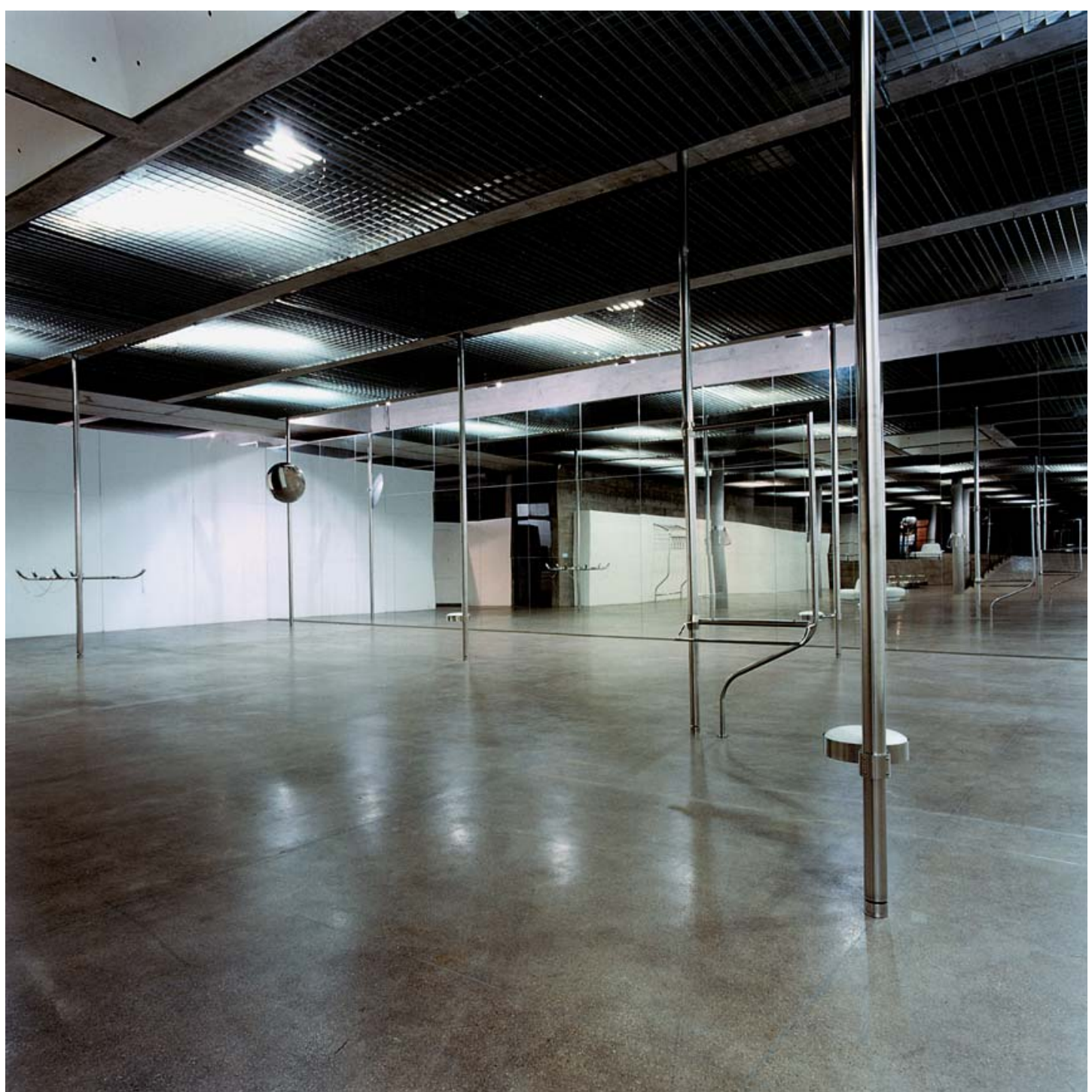

fig. 66 - "Relax'o'visions", 1998 (vista parcial) 


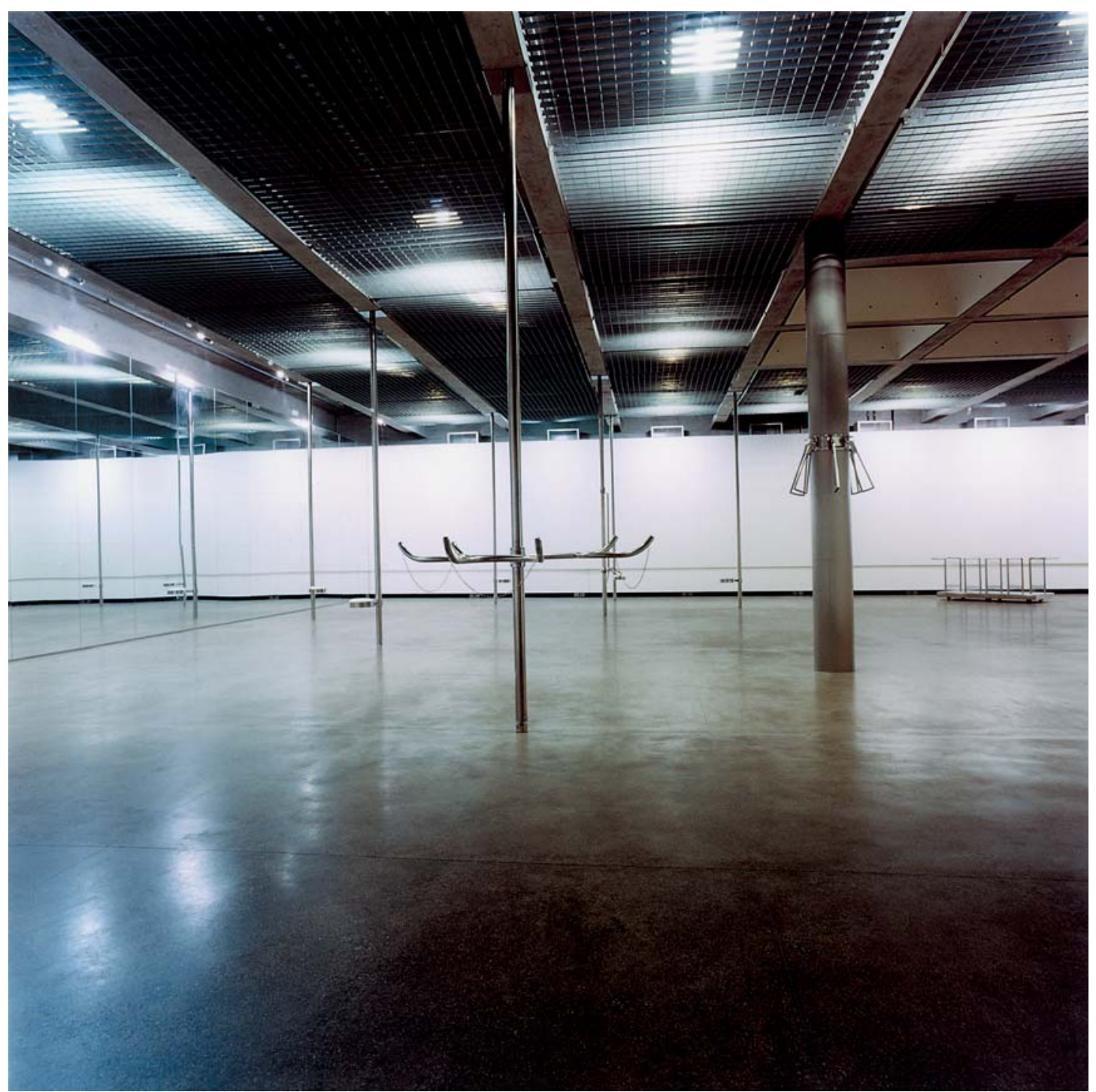

fig. 67 - "Relax'o'visions", 1998 (vista parcial) 


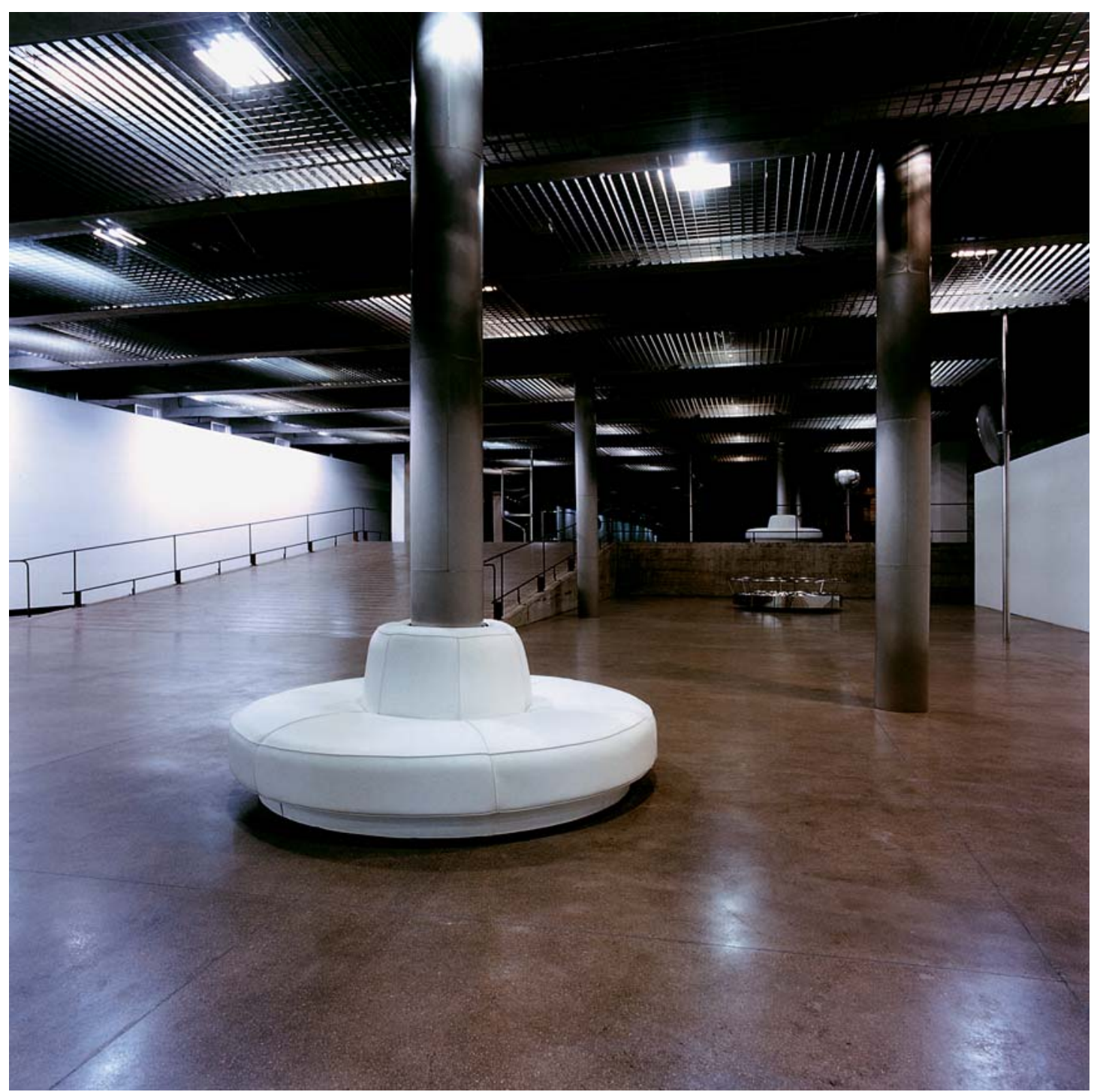

fig. 68 - "Museum's Piece", 1998 


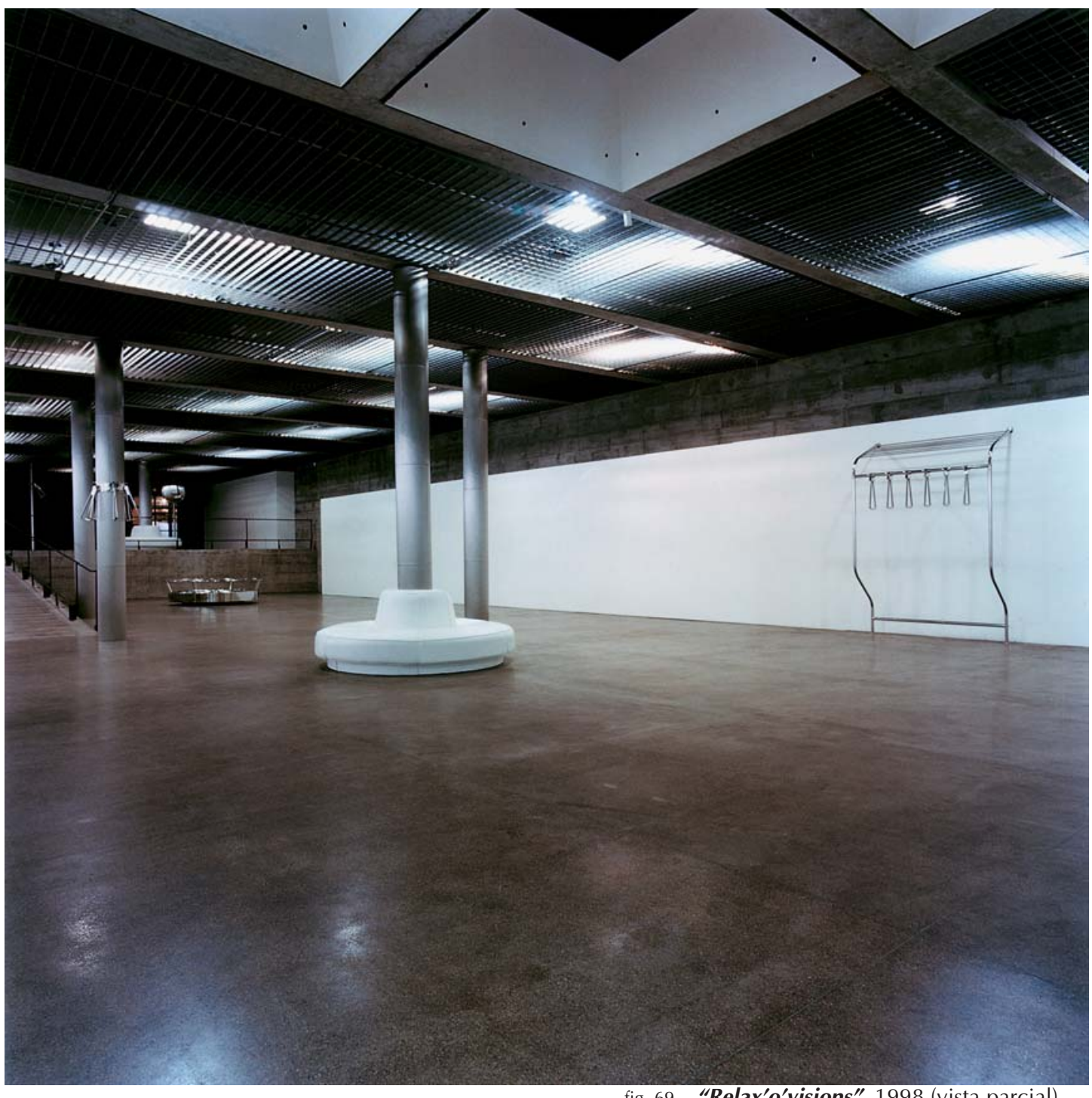

fig. 69 - "Relax'o'visions", 1998 (vista parcial) 


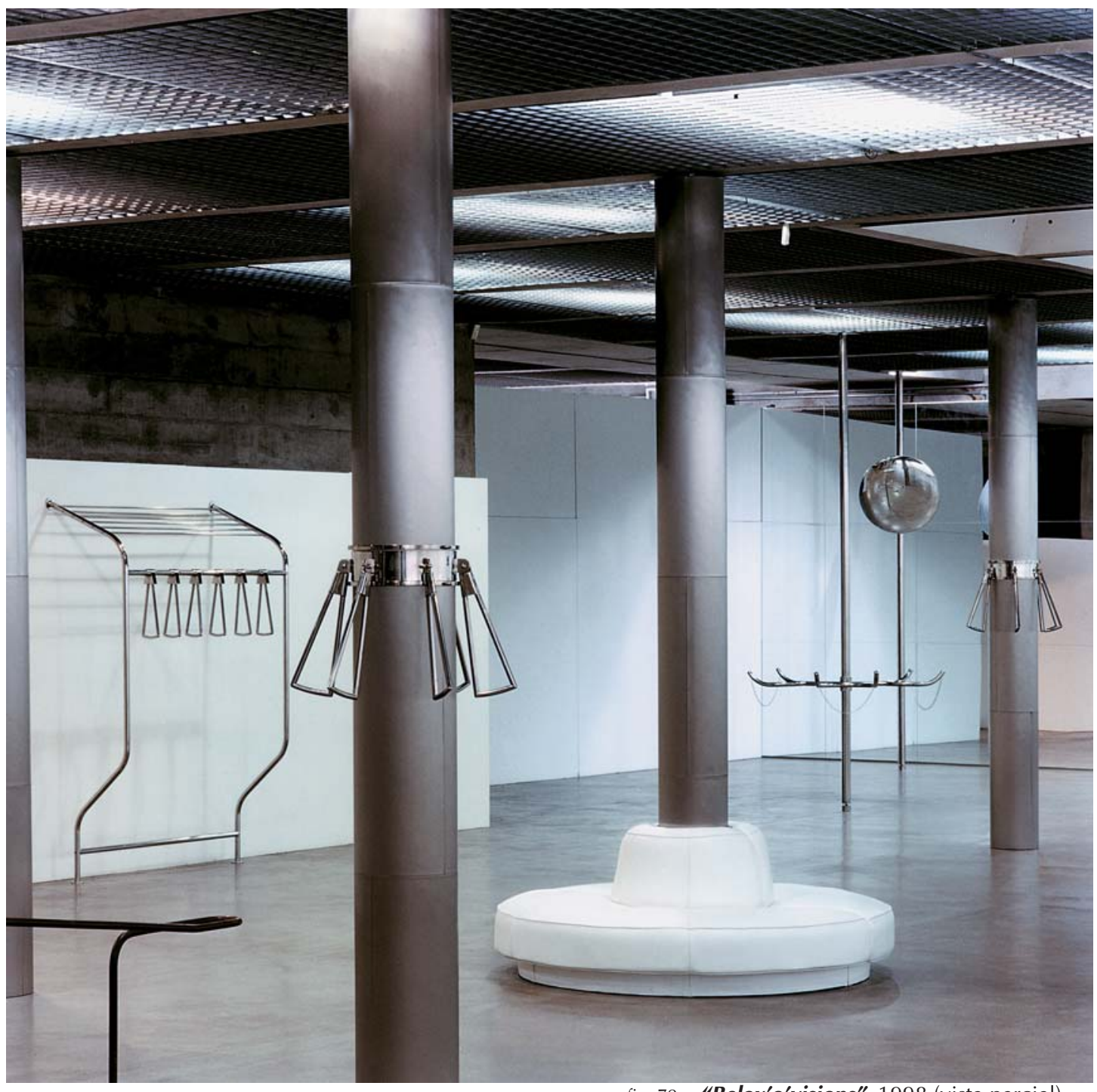

fig. 70 - "Relax'o'visions", 1998 (vista parcial) 


\subsection{A obra como um lugar de passagem no espaço público: o sujeito como navegador - "Estação Panamericana" e "Estação II"}

Não é coincidência que as obras "Estação Panamericana" e "Estação II" foram idealizadas entre 1996 e 1997, quando do meu primeiro contato com a internet. Nenhuma das duas propõe o uso da internet como suporte (a primeira se constitui como uma proposta para inserção no espaço público, e a segunda faz uso de meios eletrônicos não interativos para geração de animação em 3-D), mas ambas pretendem proporcionar uma experiência de passagem, de natureza diversa daquela que vem sendo analisada até este momento e análoga àquela que se tem na internet. Quais seriam então as características inerentes ao sistema de comunicação em rede da internet que puderam servir como base conceitual para a concepção de "Estação Panamericana" e "Estação II"?

É sabido que a internet ${ }^{94}$, chamada de "rede das redes", "meta-rede" ou "rede global", hoje passou a ser instrumento fundamental para a comunicação em todos os setores da vida contemporânea. O boom mundial da internet tem transformado radicalmente as concepções já estabelecidas de comunicação, pesquisa e marketing, devido à sua agilidade e eficiência na busca e troca de informação, e também às possibilidades de prestação de serviços e vendas de produtos on-line durante 24 horas por dia.

A internet é operada hoje, em grande parte, através de uma estrutura hipertextual e hipermídia conhecida como WWW - World Wide Web. O desenvolvimento da indústria de softwares específicos para a área das artes gráficas tem gerado novas concepções de construção de imagens virtuais, instrumentalizando produtores gráficos e artistas para transformar estas redes em sofisticados canais de informação, híbridos de texto, imagem e som.

${ }^{94}$ Criado pelo Departamento de Defesa Norte-Americano para fins militares e reestruturado pela comunidade acadêmica para servir de apoio à pesquisa e buscas de informação, este sistema foi finalmente disponibilizado para uso público a partir de 1991 e já conta hoje, com apenas nove anos de existência, com muitos milhões de usuários em todo o mundo. 
A tecnologia da internet possibilita a geração, a concentração e distribuição de informação em uma escala sem precedentes. Nesse sistema, a ausência de intermediários na transmissão de conhecimento e informação, a rapidez de acesso e a interatividade de seus usuários favorece a manutenção do que Marc Augé caracterizara como as três imagens de excesso da contemporaneidade: excesso de tempo, de espaço e de individualidade ${ }^{95}$.

Meu contato com a internet serviu para ampliar os conceitos propostos nos trabalhos anteriores, ao considerar que as questões apresentadas neste espaço de comunicação em rede são visivelmente análogas àquelas já propostas —a passagem, o trânsito-, e dessa forma passei a considerá-la também como um não-lugar. Esse, porém, seria de outra natureza, pois aqui o trânsito implica "navegar"96 através de outro tipo de espaço: o espaço virtual, aquele que propicia ao usuário uma nova experiência e percepção da relação corpoespaço-tempo. A noção de "habitar" esse outro lugar pressupõe um esquecimento e um abandono do próprio corpo físico; um estado ambíguo de anestesia/sinestesia capaz de promover o deslocamento para outros lugares que se constroem apenas virtualmente, bem como o desligamento do tempo presente que, mediado pelo sistema, se transforma em "futuro". Como na experiência do espelho, o internauta vivencia o presente (o "aqui") e o presente projetado (o "lá"), que se transforma em uma espécie de futuro — geralmente associamos ao "aqui" a ação que se desenvolve no presente e, ao "lá", aquela do passado ou do futuro. O passado corresponde ao universo da memória, enquanto a experiência projetada constitui um futuro utópico. No caso da internet, por outro lado, essa utopia tem o contraponto das conseqüências bem reais das operações que podem ser realizadas através desse sistema (compra/ venda de produtos, teleconferências, operações bancárias ou no mercado de ações...). Trata-de de uma experiência tão paradoxal quanto a do espelho —eu

\footnotetext{
${ }_{95}$ Veja acima (p. 57) a discussão desse tema.

96 "Navegador" ou "internauta" são os termos atribuídos ao usuário que sai em busca de informação. O prefixo inter, do latim, significa posição intermediária, entre. A palavra nauta significa navegante. Assim, é interessante notar que o usuário da internet seria então o navegante de um espaço intermediário, o tripulante de uma mediação.
} 
estou aqui, mas também lá onde eu não estou; e no entanto, desse "lá" irreal, eu sou capaz de transformar o mundo do "aqui".

Em um ensaio do artista Sterlac, aparentemente na esteira de McLuhan, podemos também notar a forma com que a relação do homem com a tecnologia implica, cada vez mais, a noção de "desconectar o corpo de muitas de suas funções", para plugar-se, anestesiado, em extensões tecnológicas. Vejamos o que nos diz Sterlac:

A importância da tecnologia não está simplesmente no puro poder que gera, mas no domínio da abstração que ela produz através de sua velocidade operacional e de seu desenvolvimento de sistemas sensoriais estendidos. A tecnologia pacifica o corpo e o mundo, desconecta o corpo de muitas de suas funções. DesESPERADO E DESCONECTADO, O CORPO PODE SOMENTE RECORRER À INTERFACE E À SIMBIOSE. Talvez o corpo ainda não possa renunciar à sua autonomia, mas certamente pode renunciar à sua mobilidade. O corpo plugado em uma máquina de rede precisa ser pacificado. $\mathrm{Na}$ verdade, para funcionar no futuro e para atingir verdadeiramente uma simbiose híbrida, o corpo precisará ser cada vez mais anestesiado. ${ }^{97}$

Com base na constatação de a internet ser também um sistema de não-lugares, de espaços para um usuário em condição de passagem, "ausente" ou "anestesiado", pude conceituar e designar a experiência do "navegador" como "Corpo Anestésico" que também enfocam criticamente a condição do sujeito em relação ao "sistema" e ao "meio", foram incorporadas nas obras que se seguiram e se prestam, entre outras coisas, a discutir a arte e seu sistema. Uma obra como "Visita Guiada com Amigo J9 (Para Edemar)" seria exemplo da experiência de um sujeito navegador —ele assume aí a condição de navegador do sistema da arte para submeter-se a uma experiência do não-lugar no espaço-tempo da arte. É ele quem toma a direção, tem o poder de controle e escolha, para vivenciar um deslocamento em dois níveis. O primeiro, real, do seu próprio movimento em uma cadeira motorizada, constitui uma experiência integrada pois inclui o corpo físico dentro da experiência de trânsito. O segundo, virtual,

\footnotetext{
${ }^{97}$ STERLAC. "Das estratégias psicológicas à ciberestratégias: A protética, a robótica, e a existência remota" in DomingUES, Diana. Arte no Século XXI: A Humanização das Tecnologias. São Paulo: UNESP, 1997, p. 58.

98 "Corpo Anestésico" é o título de uma pesquisa em andamento apresentada em 1996 como atividade acadêmica da Universidade de São Paulo.
} 
proporcionado por uma trilha sonora que remete a outros espaços, mantém a experiência espaço-temporal ambígua da internet e das realidades virtuais. Esse tipo de virtualidade também aparece na obra "Exit".

Mas uma experiência bem mais radical das considerações implícitas em "Corpo Anestésico" está em um projeto de caráter utópico, ficcional, que seria (hipoteticamente) implantado na cidade de São Paulo, de forma a incorporar os atributos específicos dos espaços de passagem do contexto público. Refiro-me à obra "Estação Panamericana"99, que consiste no projeto de um ambiente "desviante"100, caracterizado como um porto de espera para um corpo ausente $^{101}$ e configurando um contexto para uma "navegação" desconectada do espaço-tempo da vida. A obra busca "aprofundar os conceitos propostos em trabalhos anteriores, que tratavam da criação de ambientes e estruturas para um corpo em situação de passagem, para um usuário de não-lugares", bem como "deslocar e descontextualizar o indivíduo do seu entorno, propiciando uma nova experiência espaço-temporal dentro do espaço caótico da cidade". ${ }^{102}$

\footnotetext{
99 "Estação Panamericana" foi idealizada para a mostra "Arte no Espaço Urbano: Quinze Propostas", que pretendia discutir a relação entre a arte e o espaço público. Exposição de autoria de Aracy Amaral idealizada para a Fundação Athos Bulcão e exposta no Palácio do Itamaraty em Brasília, fez parte do evento V Fórum Brasília de Artes Visuais, no período de setembro a outubro de 1996. Os artistas foram convidados a elaborar um projeto de obra pública para local específico, à escolha de cada um, que seria exposto em forma de maquete.

${ }^{100}$ O termo "desviante" é empregado aqui no mesmo sentido que lhe é atribuído quando se diz que um comportamento é "desviante".

${ }^{101}$ De certo modo a noção de "corpo ausente" já estáva implicada em obras anteriores. STERLAC sugere que, mesmo no contexto da vida real, "nós, basicamente, funcionamos como Corpos Ausentes" (STERLAC. Opus cit., p. 54). Já discuti anteriormente a "distração" como um estado de alheamento que não impede uma ação eficiente. Em estado de "distração" o sujeito abstrai o contexto, que nesse caso poderia ser entendido como o próprio corpo. Segundo STERLAC essa situação de ausência está relacionada ao fato de que "UM CORPO É PROJETADO PARA INTERFACEAR COM O SEU AMBIENTE seus sensores são abertos-para-o-mundo (comparados ao seu inadequado sistema de vigilância). A mobilidade e a navegação do corpo pelo mundo requerem essa orientação voltada para o exterior. Sua ausência é aumentada pelo fato de que o corpo funciona habitual e automaticamente. A CONSCIENCIA É GERALMENTE AQUILO QUE OCORRE QUANDO O CORPO FUNCIONA MAL. Reforçadas pela convenção cartesiana, conveniência pessoal e projeto neurofisiológico, as pessoas funcionam apenas como mentes, imersas em névoas metafísicas. O sociólogo P. L. Berger fez uma distinção entre 'ter um corpo' e 'ser um corpo'. COMO SUPOSTOS AGENTES LIVRES, AS CAPACIDADES DE 'SER UM CORPO' SÃO RESTRINGIDAS POR 'TER UM CORPO' " (Sterlac. Opus cit., p. 54). No caso de "Estação Panamericana", assim como nos espaços virtuais a ausência do corpo assume o seu sentido literal.
}

102 Tavares, Ana Maria. "Estação Panamericana" in Amaral Aracy (org.) Quatro Mestres Escultores Brasileiros Contemporâneos; Arte e Espaço Urbano: Quinze Propostas. Brasília: Fundação Athos Bulcão, 1996, p. 44. 


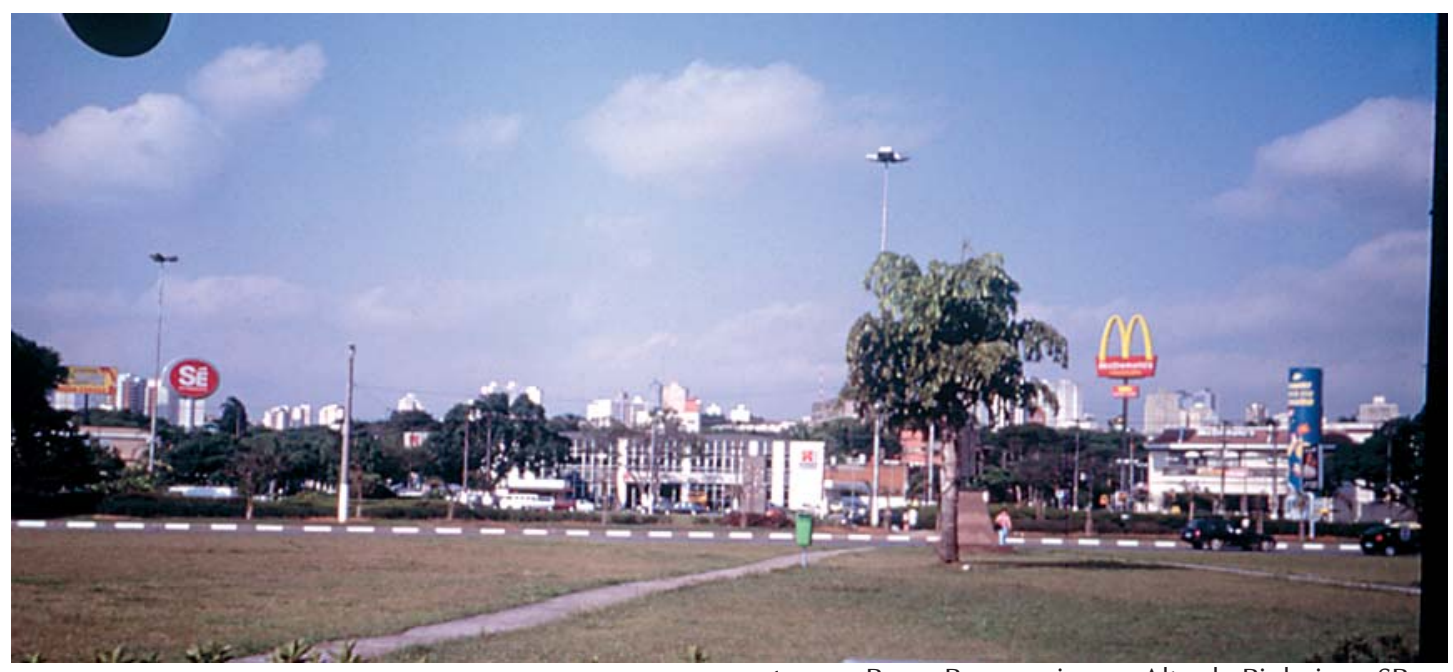

fig. 71 - Praça Panamericana, Alto de Pinheiros, SP

"Estação Panamericana" partiu da idéia de revitalização de um espaço urbano já existente, a Praça Panamericana no bairro Alto de Pinheiros em São Paulo, que seria transformada em espaço de trânsito para o "uso" público. Localizada em um bairro residencial, a praça é hoje uma área plana de onde se pode ter uma vista ampla do céu, sem interrupções visuais causadas por edifícios de grande escala ${ }^{103}$.

O projeto "compreende as relações de dois espaços distintos: túneis de passagem subterrânea e uma arena gramada, onde o espaço côncavo formado por curvas de nível abrigará uma plaza com 'corrimãos' em aço inox"104. Os acessos a esses túneis, que transportariam seus usuários com segurança para o centro da praça, estariam localizados em extremidades opostas ${ }^{105}$. "Fazendo

103 "Atualmente tomada por um trânsito intenso, a Praça Panamericana é um lugar de passagem, uma rotatória caracterizada pelo fluxo intenso de carros e cruzamento de várias ruas e avenidas, onde os serviços oferecidos ao seu redor determinam a alta rotatividade e a condição efêmera das relações que ali se dão". Estão instalados nesse espaço, serviços de bancos, lanchonetes de fast food, supermercados, postos de gasolina, floricultura, farmácia e outros. "Apesar de ser constituída por um gramado de $23.000 \mathrm{~m}^{2}$, essa praça não apresenta condições de acesso e uso seguros, nem um interesse específico capaz de atrair a comunidade local para o lazer ou contemplação" (TAVARES, Ana Maria. Opus cit., p. 44). A meu ver, o projeto de paisagismo é inadequado pois as plantas, já crescidas, formam uma espécie de cerca viva que impede a visibilidade do todo. Os usuários que são forçados a atravessar as avenidas circundantes para alcançar os pontos de ônibus ficam desprotegidos e isolados no centro da praça.

104 Tavares, Ana Maria. Opus cit., p. 44.

${ }^{105}$ De um lado, na Av. Pedroso de Morais e, de outro, na Av. Professor Fonseca Rodrigues. "Os túneis terão esteiras rolantes para ida e vinda e um corredor com estruturas de apoio para o corpo em aço inox tubular" e, acréscimo 
um percurso subterrâneo, a aproximadamente quinze metros abaixo do nível da rua, o usuário irá desembarcar nas extremidades de uma plaza de 25 x 110 metros, com piso revestido em mosaico português branco e 'corrimãos' afixados no chão. Ocupando toda a extensão do piso, os 'corrimãos' em aço inox irão configurar um outro corredor/labirinto de passagem a céu aberto"106, denominado posteriormente "Labirinto de Corrimãos".

A praça seria assim um espaço negativo escavado na terra, gramado, que, ao eliminar a linha do horizonte e a vista da cidade, proporia ao sujeito uma experiência emoldurada entre o céu e a terra. O rebaixamento do nível da rua teria a função de remover a praça da rede de sites que compõem e organizam a vida da cidade; a praça transformar-se-ia em um site isolado, que acabaria por se configurar como uma heterotopia, ao

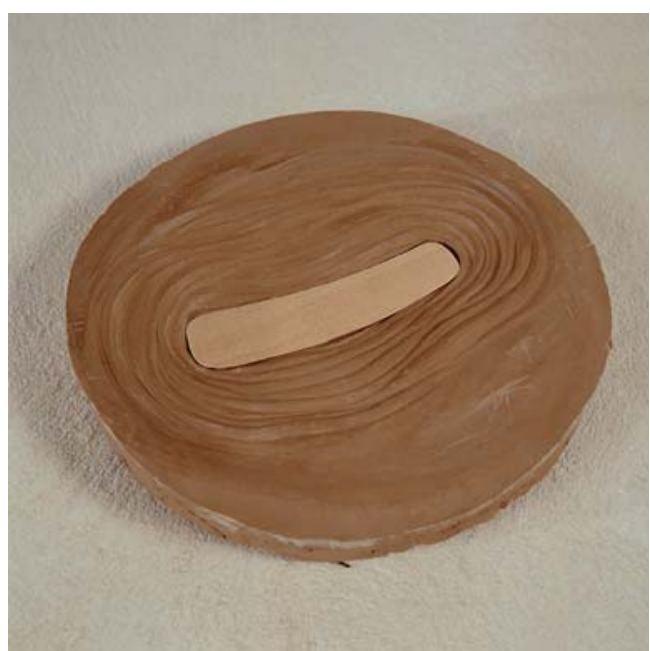

fig. 72 - "Estação Panamericana", 1996 (maquete em argila e madeira) justapor "em um único espaço real vários lugares, vários sites que são neles mesmos incompatíveis."107 Com efeito, a praça projetada em "Estação Panamericana" reuniria, em um único site, vários sites com funções estrangeiras umas às outras —uma estação, uma arena, um jardim, e um labirinto. Ao iniciar sua jornada para o interior da obra, o sujeito seria transportado para uma "meta-estação", através de túneis subterrâneos. Ao contrário de fazer parte da rede de meios de transporte públicos, que

posterior à mostra de Brasília, espelhos retrovisores. "O acesso ao centro da praça será mais seguro através dos túneis, mas poderá também ser realizado por cima, descendo pelo relevo gramado. A escolha dos materiais mantém fidelidade às características de origem de cada ambiente criado: os túneis com esteiras rolantes, relógios e painéis eletrônicos informativos, [e, agora, também espelhos retrovisores e música ambiente,] pretendem remeter aos corredores e cabines de metrôs ou mesmo às áreas públicas de passagem, como aeroportos e rodoviárias. O grande plano circular da praça preserva a idéia de um jardim gramado, um estádio ou arena, transformado em baixo-relevo com movimento para dentro da terra. O mosaico português branco é revestimento comum aos calçadões públicos." (TAVARES, Ana Maria. Opus cit., p. 44).

106 TAvares, Ana Maria. Opus cit., p. 44.

107 Foucault, Michel. Opus cit., p. 241. 

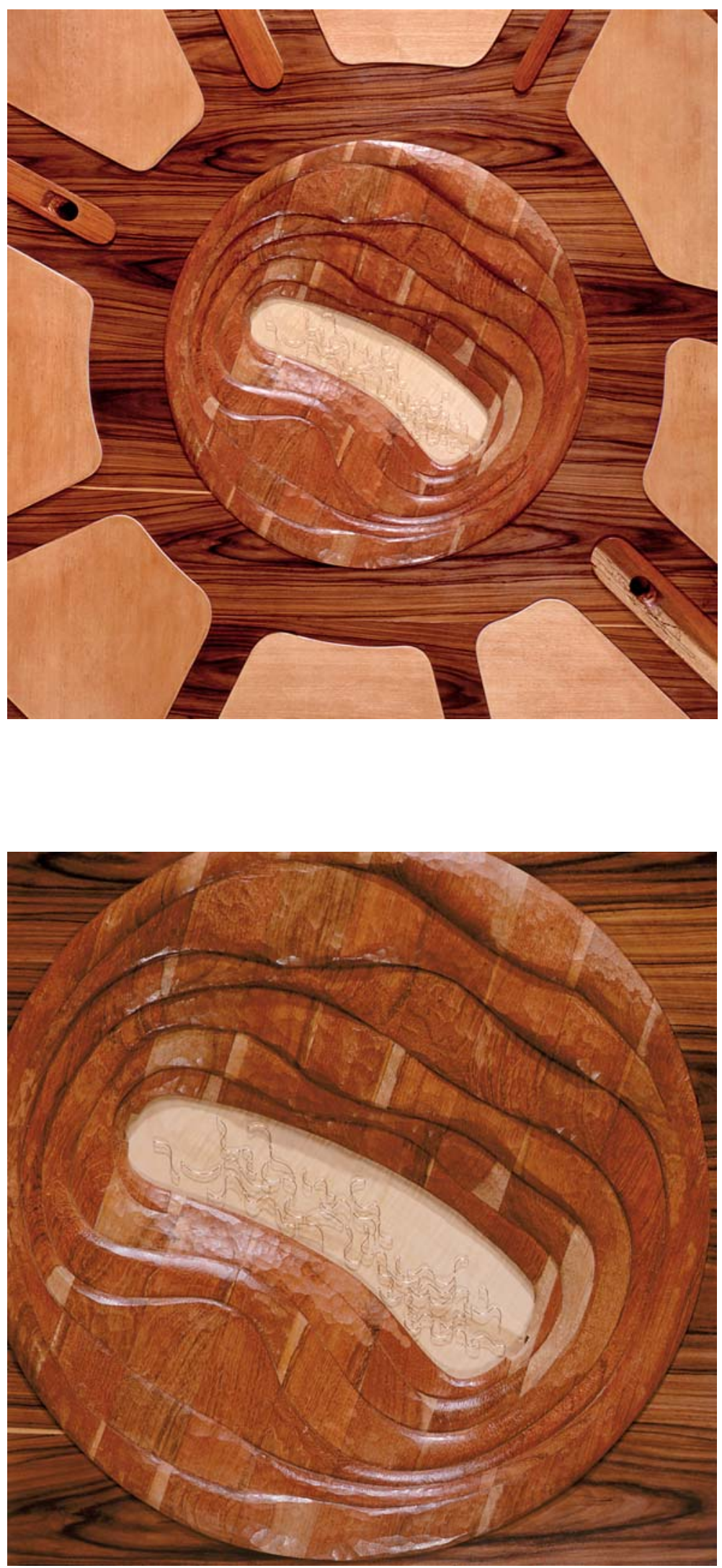

fig. 73 e 74 - "Estação Panamericana", 1996 (maquete em madeira) 
pretende garantir o funcionamento da vida na trama do espaço urbano, essa estação "raptaria" o sujeito de seu cotidiano no espaço-tempo da cidade, para fazê-lo desembarcar em uma plaza ocupada por um "Labirinto de Corrimãos" e cercada por um jardim que é também uma arena gramada de topografia irregular. O "Labirinto" conduziria ao outro túnel, sugerindo um percurso circular de entrada e saída na praça.

Nesse contexto, o sujeito poderia optar por duas posições distintas: a de usuário em ação e a de observador distanciado. A primeira deriva da função supostamente utilitária da obra e compele o sujeito, em estado de distração, a ser o passageiro que realiza o percurso sugerido — dos túneis e do "Labirinto de Corrimãos". A segunda é relativa à experiência da arena gramada, que posicionaria o sujeito na situação de um observador distanciado, contemplador e vigilante.

O isolamento do usuário do fluxo da cidade pretende enfatizar uma experiência espacial em suspensão, uma espécie de tempo que pára e perturba a noção de tempo linear e contínuo. Aqui seria possível retornar a Rosalind KRAuss quando trata de "Bola Suspensa" de Giacometti como uma "fenda na realidade contínua do espaço" (supra p.20-21). Por outro lado, é nessa experiência espaço-temporal em suspensão que reside uma outra característica das heterotopias: elas começam "a funcionar em capacidade plena quando os homens chegam em uma espécie de quebra absoluta do seu tempo tradicional"108.

Mas, na obra concreta, toda a experiência do sujeito descrita acima não passa de ficção, é apenas imaginária, pois "Estação Panamericana" se apresenta apenas como uma maquete e um pequeno dossiê composto de memorial descritivo e desenhos preparatórios ${ }^{109}$. Enquanto projeto ficcional, "Estação

${ }^{108}$ Idem, p. 242.

${ }^{109}$ O caráter ficcional do projeto pode ser visto já no catálogo da exposição de Brasília: "Os detalhamentos relativos à segurança, iluminação, tráfego de carros e a implantação de serviços básicos de apoio à população, fazem parte de um estudo, já elaborado, que deverá ser considerado por ocasião da implantação deste projeto" (TAVARES, Ana Maria. Opus cit., p. 44). Observe a menção de um estudo ligado a especificidades de engenharia, urbanismo e política urbana, que jamais foi realizado e, mais que isso, nunca esteve realmente nos planos. "Estação Panamericana" intencionalmente contém elementos ficcionais organizados de modo a constituir um setting onde uma "ação" pode se desenvolver, tal como numa narrativa romanesca, exceto que, nesse caso, o plot não é dado de modo acabado, ele é aberto, e se completa somente na experiência imaginativa do sujeito. 
Panamericana" evidencia o paradoxo comum dos ambientes virtuais, pois solicita a presença de um corpo (o transeunte na praça) que já foi extirpado a priori. Esta condição dá a "Estação Panamericana" um segundo grau de virtualidade, se comparada a "Visita Guiada com Amigo J9. Para Edemar" e "Exit", nas quais o sujeito, ainda que submetido a estímulos alheios a sua experiência espaço-temporal presente, mantinha, de todo modo, contato com a materialidade da obra (ele de fato subia na escada, de fato dirigia o carrinho).

Foi com a intenção de explorar mais profundamente esse segundo nível de virtualidade que concebi "Estação II". Também aqui o tema é a experiência da passagem, mas nesse caso, do espaço real ao contexto virtual. "Estação II" é a simulação em vídeo, obtida por meio de computação gráfica, de um percurso através da Praça Panamericana tal como projetada em "Estação Panamericana". O objetivo é estabelecer uma relação entre o espectador do sistema da arte (que no contexto dessa pesquisa é o passageiro, viajante) e o internauta que navega nos espaços virtuais. Afinal, essa é a nova fronteira da experiência espaço-temporal, mas que se constitui em analogia com o espaço do mundo tal como o percebemos. Pois se incorporamos em nosso cotidiano uma percepção do espaço como rede de sites especializados, tal como sugere Foucault, é preciso perceber que a internet também é uma rede do mesmo tipo — que conecta sites, ainda que virtuais, e se "intercepta em seu próprio emaranhado".
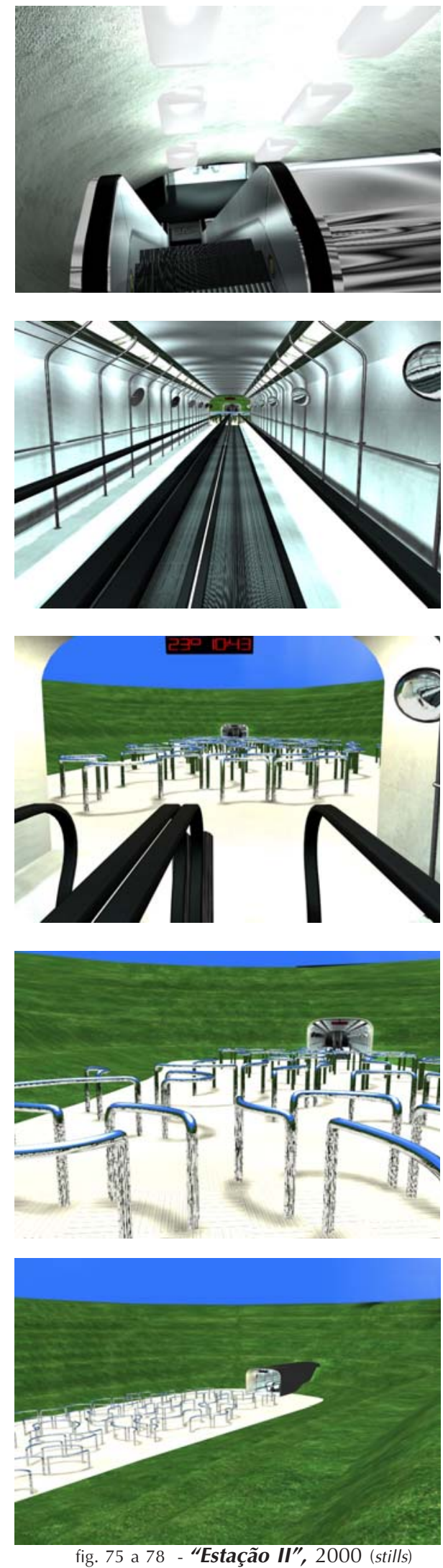

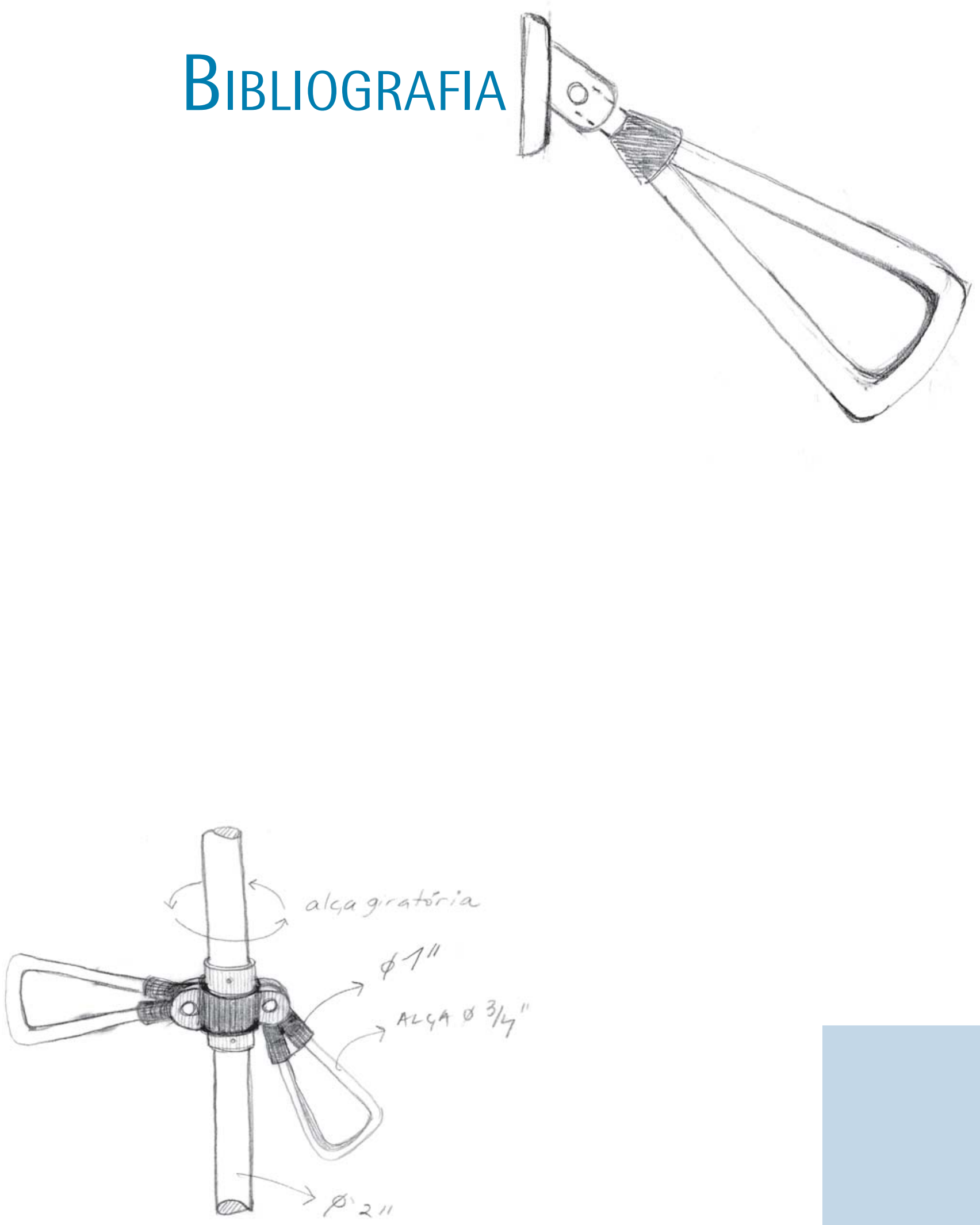
Augé, Marc. A Atualidade da Antropologia: o Sentido dos Outros. Rio de Janeiro: Editora Vozes Ltda, 1999.

- - - - Não-Lugares: Introdução a uma Antropologia da Supermodernidade. São Paulo: Papirus Editora, 1994.

Batтock, G. \& Nickas, R. The Art of Performance A Critical Anthology. New York: E.P. Dutton, Inc., 1984.

Berman, Marshall. Tudo que é Sólido Desmancha no Ar: A Aventura da Modernidade. São Paulo: Companhia das Letras, 1986

Birnholz, Alan C. "El Lissitzky and the Spectator: From Passivity to Participation" in Barron, S. \& Tuchman, M. (org.) The Avant-Garde in Russia, 1919-1930: New perspectives. Cambridge, Massachusetts: The Miт Press, 1980, pp. 98.

Butterfield, Jan. "Robert Irwin" in The Art of Light and Space. New York: Abbeville Press, 1993, pp. 17-66.

CRIMP, Douglas. On The Museum's Ruins. Cambridge, Massachusetts: The MIT Press, 1993.

Duchamp, Marcel. "The creative Act"(1953) in Sanolllet \& Peterson. The Writings of Marcel Duchamp. Oxford: Da Capo,1973, pp. 138-140.

DupuY, Jean. Collective Conciousness: Art Performances in the Seventies. New York: Performing Arts Journal Publications,1980.

Flusser, Vilém. A Dúvida. Rio de Janeiro: Relume Dumará, 1999.

Foucault, Michel. "Of Other Spaces” in Mirzoeff, Nicholas (org.) The Visual Culture Reader. London: Routledge, 1998.

Gergen, Kenneth J. The Saturated Self: Dilemmas of Identity in Contemporary Life. Basic Books, 1991.

Grossmann, Martin. "Do Ponto de Vista à Dimensionalidade" in Item, 
nº 3., fevereiro 1996, Rio de Janeiro, pp. 29-37.

Henri, Adrian. Total Art: Environments, Happenings and Performances. New York: Oxford University Press, 1974.

Jones, Amelia. Body Art: Performing the Subject. Minneapolis: University of Minnesota Press, 1998.

Krauss, Rosalind. "Sculpture in the Expanded Field" in Hertz, Richard. (org.) Theories of Contemporary Art. New Jersey: Englewood Cliffs, Prentice-Hall, Inc., 1985, pp. 215-224.

- - - - . Passages in Modern Sculpture. Cambridge, Massachusetts: Miт Press, 1977.

- - - - . "Grids" in The Originality of The Avant-Garde and Other Modernist Myths. London: Miт Press, 1985, pp. 8-22.

Levin, Kim. "Farewell to Modernism" in Hertz, Richard. (org.) Theories of Contemporary Art. New Jersey: Englewood Cliffs, Prentice-Hall, Inc., 1985, pp. 01-09.

LÉvy, Pierre. A Inteligência Coletiva: por uma Antropologia do Ciberespaço. São Paulo: Edições Loyola. 1999.

- - - - . As Tecnologias da Inteligência. São Paulo: Editora 34, 1993.

Lippard, Lucy R. “The Pink Glass Swan: Upward and Downward Mobility in the Art World" in The Pink Glass Swan: Selected Feminist Essays on Art. New York: The New Press, 1995, pp. 117-127.

Mc Evilley, Thomas. "Art in The Dark" in Hertz, Richard. (org.) Theories of Contemporary Art. New Jersey: Englewood Cliffs, Prentice-Hall, INC., 1985, pp. 287-305.

McLuhan, Marshall and Eric. Laws of Media: The New Science. Toronto: University of Toronto Press,1988.

----- Understanding Media: The Extensions of Men. London: Sphere Books Limited, 1967. 
MusIL, Robert. O Homem Sem Qualidades. Rio de Janeiro: Editora Nova Fronteira, 1989.

O'Doherty, Brian. Inside The White Cube: The Ideology of The Gallery Space. San Francisco: The Lapis Press, 1986.

Oiticica, Hélio. Aspiro ao Grande Labirinto. Rio de Janeiro: Rocco, 1986.

Oliveira, N., Oxley, N., Petry, M. Installation Art. London: Thames and Hudson, 1996.

Perniola, Mário. Do Sentir. Lisboa: Editorial Presença, 1993.

Santaella, Lúcia. "O Homem e as Máquinas" in Domingues, Diana (org.) Arte no Século XXI: A Humanização das Tecnologias. São Paulo: UnESP, 1997, pp. 3344 .

Sterlac. “Das Estratégias Psicológicas às Ciberestratégias: A protética, a Robótica e a Existência Remota" in Domingues, Diana (org.) Arte no Século XXI: A Humanização das Tecnologias. São Paulo: UnESP, 1997, pp. 33-44.

UnDeRWOOD, David. Oscar Niemeyer and the Architecture of Brazil. New York: Rizzoli. 1994.

Vaz, Paulo. "O Corpo-propriedade" in Neto Fausto e M. J., Pinto. Mídia e Sociedade: Rio de Janeiro: Diadorim, 1997.

Wigley, Mark "Prosthetic Theory: The Disciplining of Architecture" in Assemblage: A Critical Journal of Architecture and Design Culture“" 15, Agosto, 1991, p. 24 


\section{ApÊNDICE}

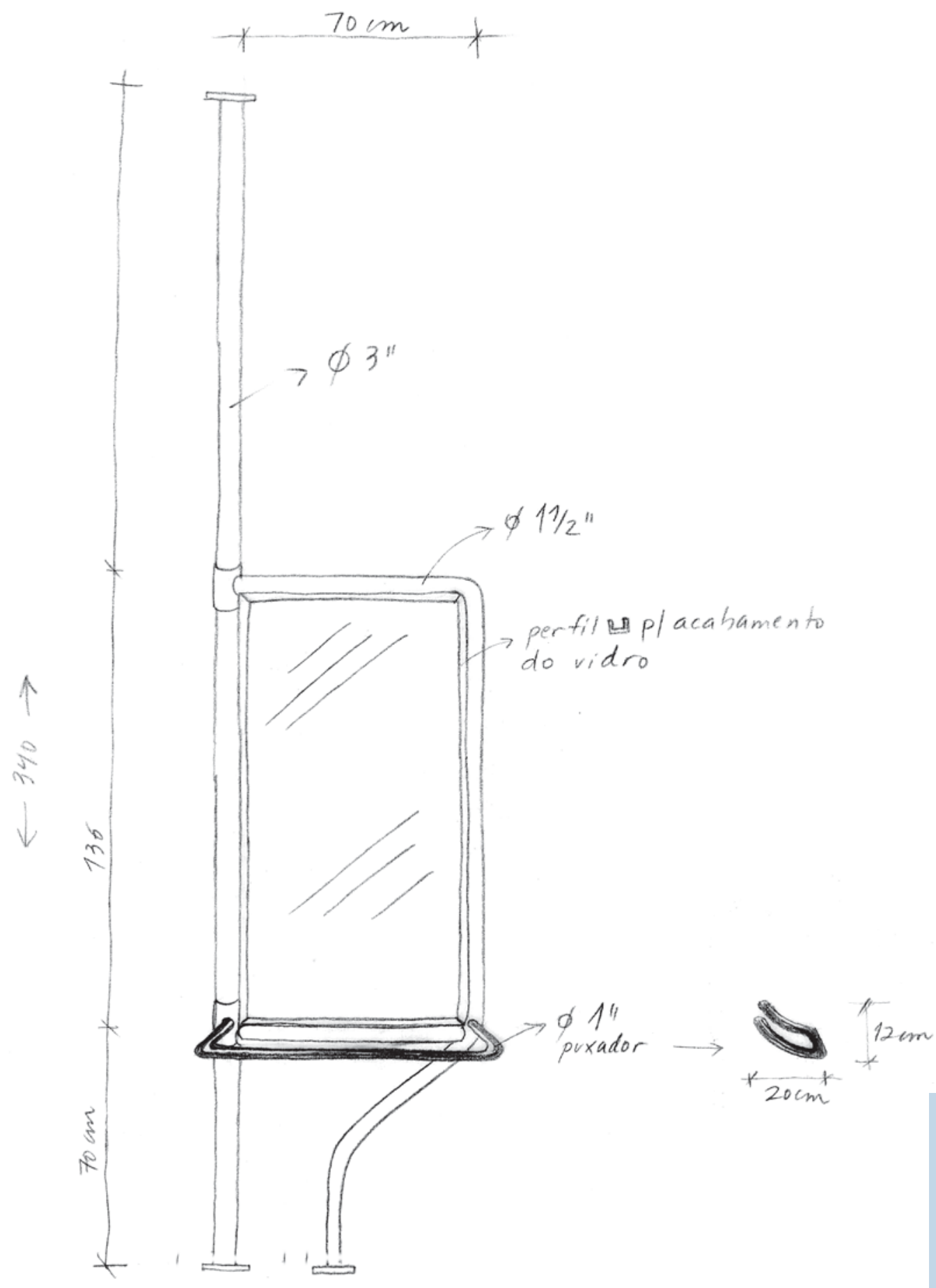




\title{
FiCHA TÉCNICA DAS OBRAS ${ }^{110}$
}

\subsection{Produção que ANtecede a Pesquisa (1985-1994)}

\author{
OBRAS REALIZADAS COMO PARTE DO MESTRADO \\ The School of The Art Institue of Chicago - Saic, Chicago \\ Setembro de 1984 a JunHO de 1986
}

\section{EXPOSIÇÕES INDIVIDUAIS}

"Cantos", 1985.

desenho sobre parede

$40 \mathrm{~m}^{2}$

Participação em Exposições:

Oxbow Gallery, Oxbow, Michigan. 1985.

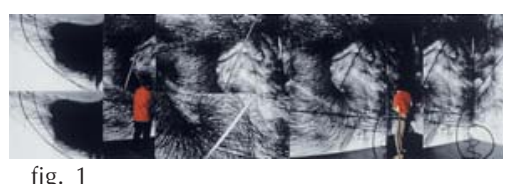

"Sem Título", 1985.

desenho e pintura sobre parede

$70 \mathrm{~m}^{2}$

Participação em Exposições:

SAIC The School of The Art Institute of Chicago. 1985.

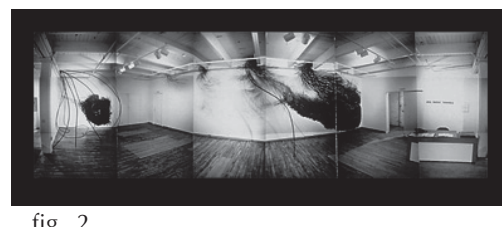

"Running Wall", 1986.

desenho e pintura sobre parede, aço carbono $70 \mathrm{~m}^{2}$

Participação em Exposições:

Superior Street Gallery, Chicago. 1995.

\section{Exposições Coletivas}

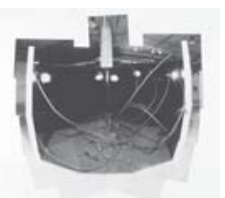

"Untameable Pocket", 1986.

$20 \mathrm{~m}^{2}$

aço carbono, tubo de borracha e tinta sintética e PVA

Participação em Exposições:

"Thesis Show", River City, Chicago. 1986.

${ }^{110}$ Somente foram relacionadas as obras e exposições citadas no corpo da tese. Portanto neste apêndice não consta a totalidade da produção realizada nesse período, mas apenas aquela que interessa para o desenvolvimento da discussão aqui proposta. As exposições são apresentadas em ordem cronológica. 


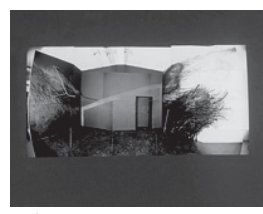

"North and South", 1986.

desenho e pintura sobre parede

$70 \mathrm{~m}^{2}$

Participação em Exposições:

"Fellowship Show", SAIC The School of The Art Institute of Chicago. 1986.

fig. 3

OBRAS REALIZADAS NO PERÍODO DE 1987 A 1991

\section{Exposıções Coletivas}

\section{"XIX Bienal Internacional de São Paulo"}

Fundação Bienal de São Paulo

Curadoria: Sheila Leirner

Data: 02 de outubro a 13 de dezembro de 1987

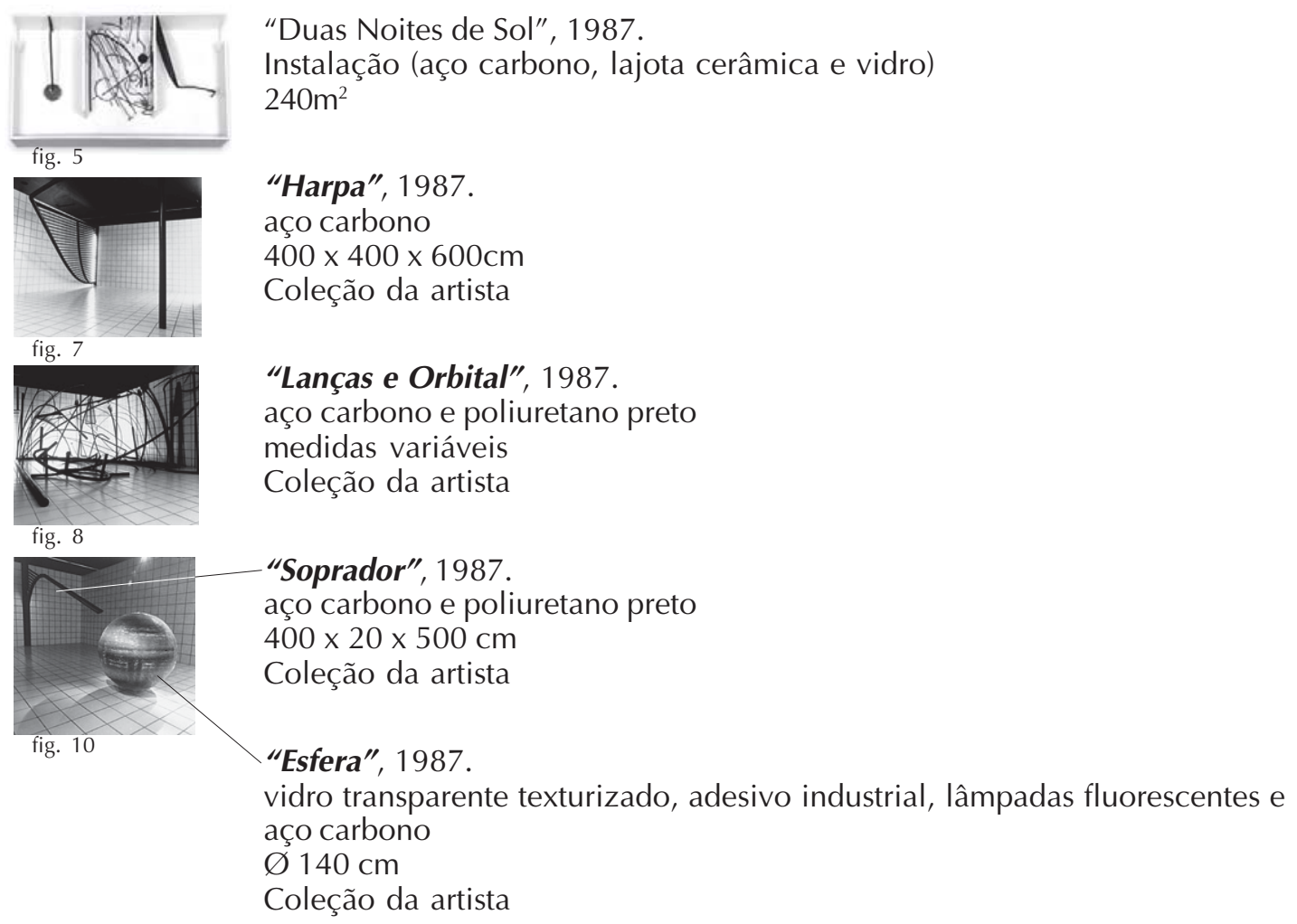

"Arte Híbrida"

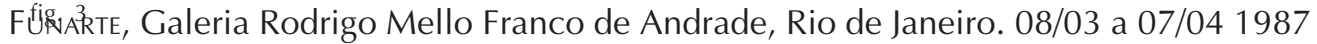

Mam Museu se Arte Moderna de São Paulo, SP. 27/04 a 21/05 1987

Espaço Cultural Banco Francês e Brasileiro, Porto Alegre, RS. 01 a 30/06 1987

Curadoria: Sérgio Romagnolo

Produção e Coordenação geral: Leda Catunda, Sérgio Romagnolo, Mônica Nador e Ana Maria Tavares 


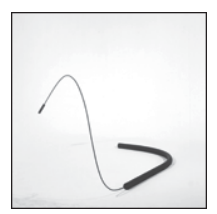

"Chicote", 1989.

aço carbono, tinta poliuretânica

medidas variáveis

Coleção João Carlos Figueiredo Ferraz

Participação em Exposições:

"Arte Híbrida"

FunARTE, Galeria Rodrigo Mello Franco de Andrade, Rio de Janeiro. 08/03 a 07/04 1987

Mam Museu se Arte Moderna de São Paulo, SP. 27/04 a 21/05 1987

Espaço Cultural Banco Francês e Brasileiro, Porto Alegre, RS.

01 a 30/06 1987

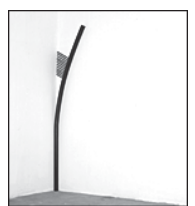

"Pente", 1989.

aço carbono

$200 \times 50 \times 8 \mathrm{~cm}$

Coleção Pedro Prado

Participação em Exposições:

"Arte Híbrida"

Funarte, Galeria Rodrigo Mello Franco de Andrade, Rio de Janeiro. 08/03 a 07/04 1987

Mam Museu se Arte Moderna de São Paulo, SP. 27/04 a 21/05 1987

Espaço Cultural Banco Francês e Brasileiro, Porto Alegre, RS.

01 a 30/06 1987

"Sem Título", 1989.

aço carbono

$231 \times 120 \times 15 \mathrm{~cm}$

Coleção Oswaldo Corrêa da Costa e Lilian Akemi Tone

Participação em Exposições:

"Arte Híbrida"

FunARTE, Galeria Rodrigo Mello Franco de Andrade, Rio de Janeiro. 08/03 a 07/04 1987

Mam Museu se Arte Moderna de São Paulo, SP. 27/04 a 21/05 1987

Espaço Cultural Banco Francês e Brasileiro, Porto Alegre, RS.

01 a 30/06 1987

"Sem Título (Escada)", 1989.

aço carbono

$221 \times 42,5 \times 50$ e $221 \times 42,5 \times 6 \mathrm{~cm}$

Coleção Marcantônio Villaça

Participação em Exposições:

"Arte Híbrida"

Funarte, Galeria Rodrigo Mello Franco de Andrade, Rio de Janeiro. 08/03 a 07/04 1987

MAm Museu se Arte Moderna de São Paulo, SP. 27/04 a 21/05 1987

Espaço Cultural Banco Francês e Brasileiro, Porto Alegre, RS.

01 a 30/06 1987

"80/90 Formas Tridimensionais: A Questão Orgânica". Curadoria: Marcantônio Vilaça.

Museu Municipal de Arte. Curitiba. 16/12/91 a 17/02/92 


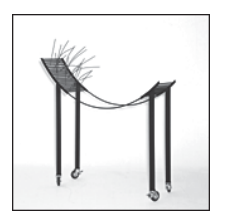

\author{
"Mesa Curva", 1989. \\ aço carbono e alumínio anodizado \\ $146 \times 40 \times 165 \mathrm{~cm}$ \\ Coleção Ricard Akagawa \\ Participação em Exposições: \\ "Arte Híbrida"
}

FunARTE, Galeria Rodrigo Mello Franco de Andrade, Rio de Janeiro. 08/03 a 07/04 1987

Mam Museu se Arte Moderna de São Paulo, SP. 27/04 a 21/05 1987

Espaço Cultural Banco Francês e Brasileiro, Porto Alegre, RS.

01 a 30/06 1987

"Arte Brasileña: La Nueva Generación". Curadoria Aracy Amaral Fundacíon Museo de Bellas Artes, Caracas. 11/04 a 19/05 de 1991.

"O Beijo", 1989

aço carbono e alumínio anodizado

$120 \times 60 \times 200 \mathrm{~cm}$

Coleção MAB Museu de Arte de Brasília

Participação em Exposições:

"Arte Híbrida"

Funarte, Galeria Rodrigo Mello Franco de Andrade, Rio de Janeiro. 08/03 a 07/04 1987

Mam Museu se Arte Moderna de São Paulo, SP. 27/04 a 21/05 1987

Espaço Cultural Banco Francês e Brasileiro, Porto Alegre, RS. 01 a 30/06 1987

Casa de Cultura de Caxias do Sul, Caxias. 1989.

"Prêmio Brasília de Artes Plásticas", MAB Museu de Arte de Brasília Brasília

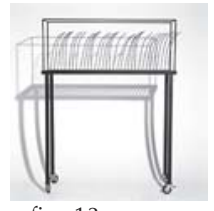

"Aquário", 1989.

$194 \times 150 \times 50 \mathrm{~cm}$

aço carbono, alumínio anodizado e rodinhas

Coleção Casa da Cultura de Ribeirão Preto. 1990

Participação em Exposições:

"Arte Híbrida"

FunARTE, Galeria Rodrigo Mello Franco de Andrade, Rio de Janeiro. 08/03 a

07/04 1987

Mam Museu se Arte Moderna de São Paulo, SP. 27/04 a 21/05 1987

Espaço Cultural Banco Francês e Brasileiro, Porto Alegre, RS. 01 a 30/06 1987

Casa de Cultura de Caxias do Sul, Caxias. 1989.

16음 São de Ribeirão Preto Ribeirão Preto. 1991.

\author{
"Apropriações" \\ Paço das Artes, São Paulo, SP \\ Direção: Sara Goldmann \\ Coordenação Geral: Vitória Daniela Bousso \\ Curadoria: Tadeu Chiarelli \\ Data: 02 a 30 de outubro de 1990
}




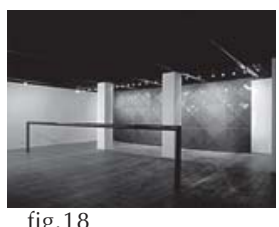

"Bico de Diamante", 1990.

aço carbono, chapa galvanizada e poliuretano metálico $70 \mathrm{~m}^{2}$

Coleção da artista

Participação em Exposições:

“Apropriações". Paço das Artes, São Paulo. 1990.

"XXI Bienal Internacional de São Paulo"

Fundação Bienal de São Paulo

Curadoria:

Data: 21 de setembro a 10 de dezembro de 1991

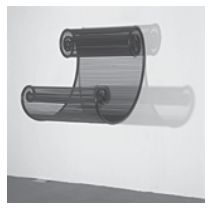

"Pergaminho", 1991.

aço carbono e alumínio

$143 \times 115 \times 140 \mathrm{~cm}$

Coleção da artista

Participação em Exposições:

"XXI Bienal Internacional de São Paulo", São Paulo. 1991.

"The Art of Ultramodern Contemporary Brazil", The National Museum of Women in the Arts. Washington D. C., UsA. 1993.

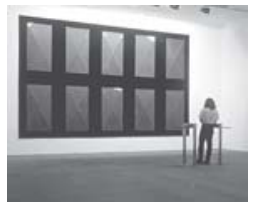

fig. 20
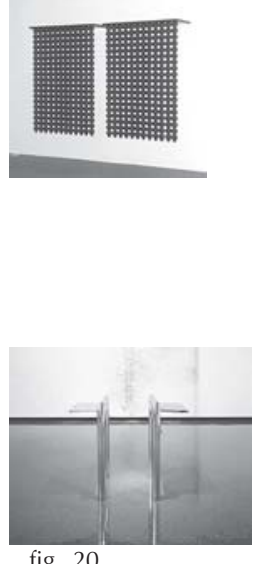

fig. 20
"Tapete", I a XX, 1991.

aço galvanizado, veludo, madeira e tinta poliuretânica

$192 \times 173 \times 4 \mathrm{~cm}$ (cada peça)

Coleções e Tânia Hammud, David e Pompéia Tavares, Eduardo Brandão,

Rômulo Fialdini, Brito Cimino

Participação em Exposições:

"XXI Bienal Internacional de São Paulo", São Paulo. 1991.

"The Art of Ultramodern Contemporary Brazil", The National Museum of Women in the Arts. Washington D. C., UsA. 1993.

"Dois Rosários", 1991.

aço carbono, madeira

$270 \times 200 \times 50 \mathrm{~cm}$

Coleção Luciana Brito

Participação em Exposições:

"XXI Bienal Internacional de São Paulo", São Paulo. 1991.

"The Art of Ultramodern Contemporary Brazil", The National Museum of Women in the Arts. Washington D. C., UsA. 1993.

"Alguns Pássaros (Those in Flight)", 1991.

$110 \times 140 \times 70 \mathrm{~cm}$

aço carbono cromado

Coleção Fausto Godoy

Participação em Exposições:

"XXI Bienal Internacional de São Paulo", São Paulo. 1991.

"Encounters", The Betty Rymer Gallery, Chicago, UsA. 1992.

"The Art of Ultramodern Contemporary Brazil", The National Museum of Women in the Arts. Washington D. C., UsA. 1993.

"Ao Cubo", Paço das Artes, São Paulo. 1997. 
Obras inÉditas

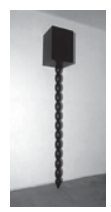

fig. 15

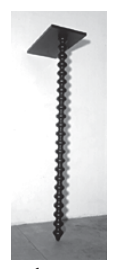

fig. 14

“Logbook (Caixa-Preta)", 1992.

madeira e fórmica

$350 \times 52 \times 52 \mathrm{~cm}$

Coleção da artista

"Plataforma", 1992.

madeira

$350 \times 52 \times 100 \mathrm{~cm}$

Coleção da artista

\section{EXPOSIÇÕES INDIVIDUAIS}

Gabinete de Arte Raquel Arnaud

27 de novembro a 21 de dezembro de 1990

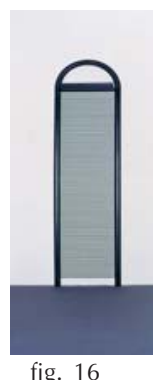

fig. 16

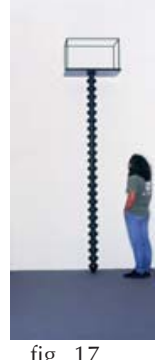

fig. 17

"Container", 1990.

aço carbono e madeira

$350 \times 80 \times 52 \mathrm{~cm}$

Coleção Mam Museu de Arte Moderna de São Paulo

Participação em Exposições:

Gabinete de Arte Raquel Arnaud, São Paulo. 1990.

XXI Bienal Internacional de São Paulo, São Paulo. 1991.

"Bienal Brasil Século XX", Fundação Bienal de São Paulo. Curadoria Agnaldo Farias. 1994.

"Doações Recentes", Museu de Arte Moderna, São Paulo. Curadoria: Tadeu Chiarelli 1996.

"Arte Brasileira no Acervo do MAM de São Paulo", Centro Cultural BB, Rio de Janeiro. Curadoria: Tadeu Chiarelli 1998.

"Entre a arte e o design: Acervo do MAM", São Paulo.Curadoria: Tadeu

Chiarelli. 2000

"Escada", 1990

aço carbono

$350 \times 80 \times 52 \mathrm{~cm}$

Coleção MAm Museu de Arte Moderna de São Paulo

Participação em Exposições:

Gabinete de Arte Raquel Arnaud, São Paulo. 1990.

XXI Bienal Internacional de São Paulo, São Paulo. 1991.

"Bienal Brasil Século XX", Fundação Bienal de São Paulo. Curadoria

Agnaldo Farias. 1994.

"Doações Recentes", Museu de Arte Moderna, São Paulo. Curadoria: Tadeu Chiarelli 1996.

"Arte Brasileira no Acervo do MAM de São Paulo", Centro Cultural BB, Rio de Janeiro. Curadoria: Tadeu Chiarelli 1998.

"Entre a arte e o design: Acervo do MАM", São Paulo.Curadoria: Tadeu Chiarelli. 2000 


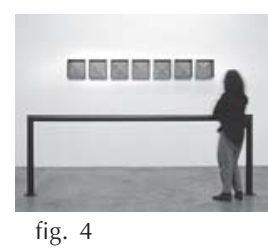

"Paisagem", 1990.

aço carbono, madeira, chapa galvanizada, tinta poliuretanica $110 \times 300 \times 300 \times \mathrm{cm}$

Coleção da artista

Participação em Exposições:

Gabinete de Arte Raquel Arnaud, São Paulo. 1990.

"Pendurador", 1990.

aço carbono

$200 \times 170 \times 70 \mathrm{~cm}$

Coleção da artista

Participação em Exposições:

Gabinete de Arte Raquel Arnaud, São Paulo. 1990.

"Bienal Brasil Século XX", Fundação Bienal de São Paulo. 1994.

$16^{\circ}$ Salão de Ribeirão Preto. Ribeirão Preto. 1991.

Coleção Casa da Cultura de Ribeirão Preto. 1990.

"Tapete", 1990.

aço galvanizado, madeira, veludo, tinta poliuretânica metalizada $4 \times 194 \times 494 \mathrm{~cm}$

Coleção da artista

Participação em Exposições:

Gabinete de arte Raquel Arnaud, São Paulo. 1990.

\subsection{Produção da Pesquisa (1995-2000)}

\section{EXPOSIÇÕES INDIVIDUAIS}

"Rotatórias"

Galeria Millan, São Paulo

Produção: Ana Maria Tavares e Luciana Brito

Data: 06 a 31 de março de 1996

"Belmont Station", 1996.

aço inox, couro

$130 \times 140 \times 50 \mathrm{~cm}$

Coleção da artista

Participação em Exposições:

"Rotatórias", Galeria Millan, São Paulo. 1996.

Coletiva Brito Cimino, São Paulo. 1997.

"FIAC, Foire Internationale d'Árte Contemporain", Paris. 1999. 


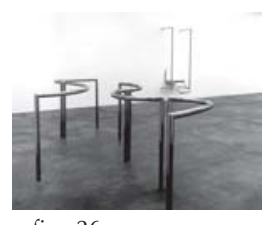

fig. 26

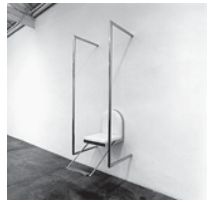

fig. 32

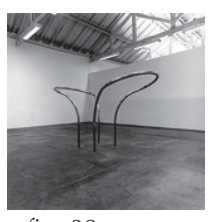

fig. 30

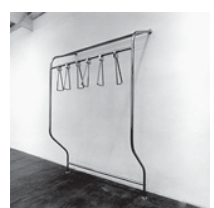

fig. 27

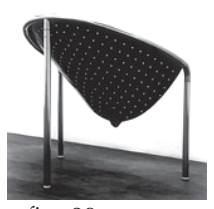

fig. 29

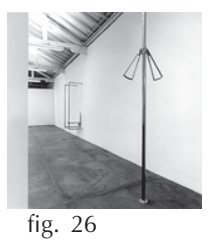

“Corrimão", 1996.

aço inox

$100 \times 90 \times 300 \mathrm{~cm}$

Coleção Instituto Itaú Cultural

Participação em Exposições:

"Rotatórias", Galeria Millan. 1996.

"Metal e suas LigaAções", SEsc Pompéia, São Paulo. 1996.

"Diversidade da Escultura Contemporânea Brasileira", Instituto Itaú

Cultural. 1997.

"Guarda-Corpo", 1996.

aço inox, couro e espuma

$250 \times 90 \times 70 \mathrm{~cm}$

Coleção Eduardo Brandão

Participação em Exposições:

“Rotatórias", Galeria Millan, São Paulo. 1996.

"Rotatória",1996.

aço inox

$130 \times 102 \times 240 \mathrm{~cm}$

Coleção Luciana Brito

Participação em Exposições:

“Rotatórias", Galeria Millan, São Paulo. 1996.

"Cabine", 1996.

aço inox e teflon

$250 \times 160 \times 70 \mathrm{~cm}$

Coleção da artista

Participação em Exposições:

"Rotatórias", Galeria Millan, São Paulo. 1996.

“Relax'o'visions", MuBE Museu Brasileiro da Escultura, São Paulo. 1998.

"Escorredor", 1996.

aço inox e teflon

$130 \times 123 \times 100 \mathrm{~cm}$

Coleção José Olympio eAndreia Pereira

Participação em Exposições:

"Rotatórias", Galeria Millan, São Paulo. 1996.

"Coluna com duas alças", 1997.

aço inox e teflon

$450 \times \varnothing 95 \mathrm{~cm}$

Coleção Ricardo Semler

Participação em Exposições:

"Rotatórias", Galeria Millan, São Paulo. 1996. 
"Porto Pampulha"

Map Museu de Arte da Pampulha. Belo Horizonte, MG.

Direção: Priscila Freire

Coordenação Geral: Elisa Campos

Produção: Ana Maria Tavares e Galeria Brito Cimino

Data: 15 de outubro a 16 de novembro de 1997

\section{"Relax'o'visions"}

MuBE Museu Brasileiro da Escultura, SP

Direção: Fábio Magalhães e Inês Raphaelian

Coordenação Geral: Inês Raphaelian

Produção: Ana Maria Tavares e Galeria Brito Cimino

Data: 28 de setembro a 25 de outubro de 1998

"Carrinho", 1997.

aço inox, 1997

$150 \times 50 \times 150 \mathrm{~cm}$

Coleção da artista

Participação em Exposições:

"Porto Pampulha", MAP Museu de Arte da Pampulha, Belo Horizonte. 1997.

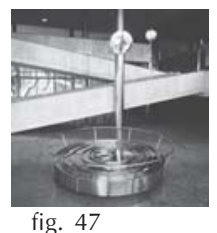

fig. 47

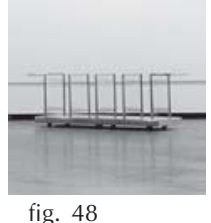

"Carroussel (Para Duchamp)", 1997.

aço inox e espelho

$58 \times \varnothing 280 \mathrm{~cm}$

Coleção da artista

Participação em Exposições:

"Porto Pampulha", MAP Museu de Arte da Pampulha, Belo Horizonte. 1997.

“Relax'o'visions", MuBE Museu Brasileiro da Escultura, São Paulo. 1998.

"Cavalete", 1997.

aço inox e rodas

$110 \times 70 \times 174 \mathrm{~cm}$

Coleção da artista

Participação em Exposições:

"Porto Pampulha", MAP Museu de Arte da Pampulha, Belo Horizonte. 1997.

"Relax'o'visions", MuBE Museu Brasileiro da Escultura, São Paulo. 1998.

"Panorama 99", Mам Museo de Arte Moderna de Fortaleza, Centro Dragão do Mar de Arte e Cultura, Fortaleza. 2000.

"Vagão (BHTrans)",1997.

aço inox, espelho, vidro e rodízios

$96 \times 85 \times 186 \mathrm{~cm}$

Coleção da artista

Participação em Exposições:

"Porto Pampulha", MAP Museu de Arte da Pampulha, Belo Horizonte. 1997.

“Relax'o'visions", MuBE Museu Brasileiro da Escultura, São Paulo. 1998.

"Publicação III", Galeria Brito Cimino, São Paulo. 2000. 


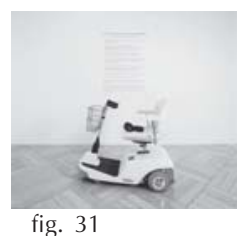

fig. 31

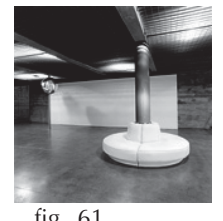

fig. 61

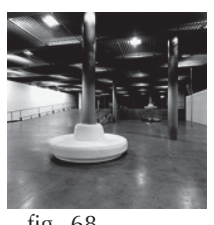

fig. 68
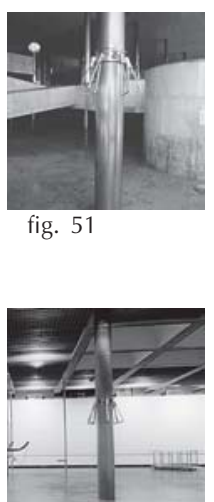

fig. 67

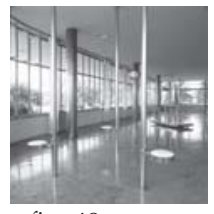

fig. 48
"Visita Guiada com Amigo J9 (Para Edemar)", 1997.

cadeira motorizada, couro, borracha, diskman e fone de ouvido

$100 \times 50 \times 110 \mathrm{~cm}$

Coleção Ricard Akagawa

Trilha sonora: "Suite Para Edemar"

Tempo: $16^{\prime}$

Edição de Audio: Eduardo Tibira

Studio: Turtle Skull

Concepção e Direção: Ana Maria Tavares

Data: 1997

Participação em Exposições:

"Ao Cubo", Paço das Artes, São Paulo, 1997.

"Porto Pampulha", MuBE Museu de Arte da Pampulha, Belo Horizonte, 1997.

"Collector's Item", 1997.

madeira, couro branco, aço carbono, aço inox e espelho retrovisor $400 \times \varnothing 191 \mathrm{~cm}$

Coleção Fábio e Mônica Faiçal

Participação em Exposições:

"Porto Pampulha", MAP Museu de Arte da Pampulha, Belo Horizonte. 1997.

“Relax'o'visions", MuBE Museu Brasileiro da Escultura, São Paulo. 1998.

"Seleção", Galeria Brito Cimino, São Paulo. 1998.

"Museums' Piece", 1997.

madeira, couro branco, aço carbono, aço inox e espelho retrovisor

$\varnothing 191$ x $400 \mathrm{~cm}$

Coleção da artista

Participação em Exposições:

"Porto Pampulha", MAP Museu de Arte da Pampulha, Belo Horizonte. 1997.

"Relax'o'visions", MuBE Museu Brasileiro da Escultura, São Paulo. 1998.

“Coluna com seis alças", I e II, 1997.

aço inox

$1000 \times \varnothing 137 \mathrm{~cm}$

coleção da artista

Participação em Exposições:

"Porto Pampulha", MAP Museu de Arte da Pampulha, Belo Horizonte. 1997.

"Coluna Niemeyer com seis alças", I e II, 1998.

aço inox

$400 \times \varnothing 131 \mathrm{~cm}$

coleção da artista

Participação em Exposições:

“Relax'o'visions", MuBE Museu Brasileiro da Escultura, São Paulo. 1998.

"Coluna com banco de elevador" I a V ,1997.

aço inox e couro branco

$340 \times 48 \mathrm{~cm} \times 30 \mathrm{~cm}$

Coleção da artista e Luciana Brito

Participação em Exposições:

"Porto Pampulha", MAP Museu de Arte da Pampulha, Belo Horizonte. 1997.

"Relax'o'visions", MuBe, Museu Brasileiro da Escultura, São Paulo. 1998. 


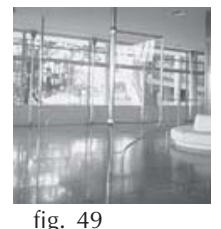

fig. 49
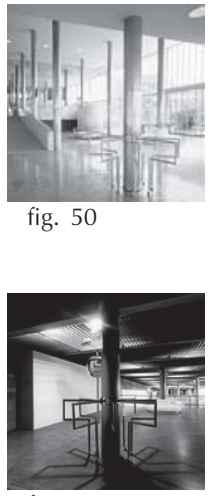

fig. 60
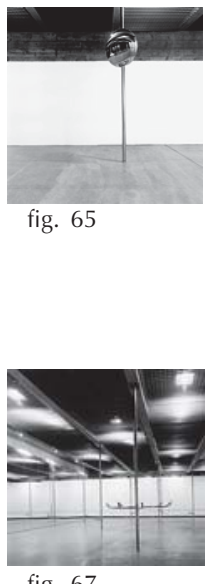

fig. 67
“Coluna com biombo e prateleira" | e II, 1997.

aço inox e vidro

$340 \times 92 \times 26, \mathrm{~cm}$

Coleção Simone Fontana Reis

Participação em Exposições:

"Porto Pampulha", MAP Museu de Arte da Pampulha, Belo Horizonte. 1997.

“Relax'o'visions", MuBE Museu Brasileiro da Escultura, São Paulo. 1998.

"Coluna com biombo e puxador" I e II, 1997.

aço inox e vidro

$340 \times 92 \times 26 \mathrm{~cm}$

Coleção da artista e Galeria Brito Cimino

Participação em Exposições:

"Porto Pampulha", MAP Museu de Arte da Pampulha, Belo Horizonte. 1997.

“Relax'o'visions", MuBE Museu Brasileiro da Escultura, São Paulo. 1998.

"Seleção", Galeria Brito Cimino, São Paulo. 1998.

"Coluna com catraca", 1997.

aço inox e rodízios

$340 \times \varnothing 176 \mathrm{~cm}$

Coleção da artista

Participação em Exposições:

"Porto Pampulha", MAP Museu de Arte da Pampulha, Belo Horizonte. 1997.

"Coluna Niemeyer com catraca", 1998.

aço inox, aço carbono, madeira e rodízios

$270 \times \varnothing 176 \mathrm{~cm}$

Coleção da artista

Participação em Exposições:

“Relax'o'visions", MuBE Museu Brasileiro da Escultura, São Paulo. 1998.

"Coluna com retrovisor" I a IX, 1997.

aço inox e espelho parabólico

medidas variáveis

Coleções da artista e Tai Castilho, Fany Hara Kovesi, Tomas Lorente

Participação em Exposições:

"Porto Pampulha", MAP Museu de Arte da Pampulha, Belo Horizonte. 1997.

"Relax'o'visions", MuBE Museu Brasileiro da Escultura, São Paulo. 1998.

"Seleção", Galeria Brito Cimino, São Paulo. 1998.

"Coluna com roleta", 1997.

aço inox

$340 \times \varnothing 182 \mathrm{~cm}$

Coleção da artista

Participação em Exposições:

"Porto Pampulha", MAP Museu de Arte da Pampulha, Belo Horizonte. 1997.

“Relax'o'visions", MuBE Museu Brasileiro da Escultura, São Paulo. 1998. 
"Coluna com três alças", 1997.

aço inox

medidas variáveis

Coleção da artista

Participação em Exposições:

"Porto Pampulha", MAP Museu de Arte da Pampulha, Belo Horizonte. 1997.

“Relax'o'visions", MuBE Museu Brasileiro da Escultura, São Paulo. 1998.

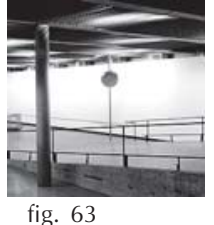

"Coluna Niemeyer" I e II, 1997.

aço inox, aço carbono e madeira

$400 \times \varnothing 35 \mathrm{~cm}$

Coleção da artista

Participação em Exposições:

"Porto Pampulha", MAP Museu de Arte da Pampulha, Belo Horizonte. 1997.

“Relax'o'visions", MuBE Museu Brasileiro da Escultura, São Paulo. 1998.

\section{"Estação II"}

Centro Cultural Maria Antônia, São Paulo, SP

Direção: Lorenzzo Mammi

Coordenação Geral: Lorenzzo Mammi

Produção: Ana Maria Tavares e Galeria Brito Cimino

Data: 13 de julho a 13 de agosto de 2000

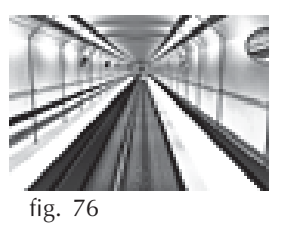

"Estação II", 2000.

animação em 3D para projeção em larga escala

Animação: Eduardo Nogueira

Trilha sonora: Ruggiero

Direção: Ana Maria Tavares

Participação em Exposições:

"Estação II", Centro Cultural Maria Antônia, São Paulo, 2000

\section{Exposições Coletivas}

"Entre o Desenho e a Escultura"

MAM, Museu de Arte Moderna de São Paulo, SP

Direção: Cacilda Teixeira da Costa

Curadoria: Lisette Lagnado

Data: 27 Junho a 30 de julho de 1995

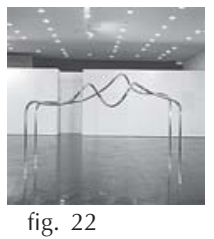

"Serpentinata", 1996.

aço inox

$210 \times 120 \times 350 \mathrm{~cm}$

Coleção Ricardo Semler

Participação em Exposições:

"Entre o Desenho e a Escultura", MAM Museu de Arte Moderna de São

Paulo. 1996. 
"Arte e Espaço Urbano: Quinze Propostas"

Palácio do Itamaraty, Brasília, DF

Organização: Fundação Athos Bulcão

Coordenação Geral: Cláudio Telles, Eduardo Cabral e Liane Mülenberg

Curadoria: Aracy Amaral

Data: 07 de setembro a 15 de outubro de 1996

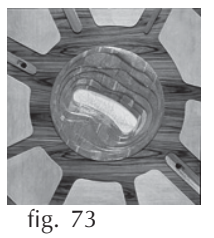

"Estação Panamericana", 1995.

maquete em madeira

$15 \times 102 \times 102 \mathrm{~cm}$

Coleção da artista

Participação em Exposições:

"Arte e Espaço Urbano: Quinze Propostas". Palácio do Itamaraty e Fundação Athos Bulcão, Brasília, DF. 1996.

\section{"Ao Cubo"}

Paço das Artes, São Paulo, SP

Direção: Vitória Daniela Bousso

Curadoria: Luciana Brito e Martin Grossmann

Produção: Luciana Brito e Martin Grossmann

Data: 11 de março a 06 de abril de 1997

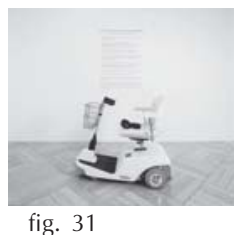

"Visita Guiada com Amigo J9 (Para Edemar)", 1997.

cadeira motorizada, couro, diskman e fone de ouvido

$100 \times 50 \times 110 \mathrm{~cm}$

Coleção Ricard Akagawa

Trilha sonora: "Suite Para Edemar"

Tempo: $16^{\prime}$

Edição de Audio: Eduardo Tibira

Studio: Turtle Skull

Concepção e Direção: Ana Maria Tavares

Data: 1997

Participação em Exposições:

"Ao Cubo", Paço das Artes, São Paulo, 1997.

"Porto Pampulha", MuBE Museu de Arte da Pampulha, Belo Horizonte, 1997.

"II Semana Fernando Furlanetto: Fotografia"

Teatro Municipal São João da Boa Vista, SP

Organização: Prefeitura Municipal de São João da Boa Vista

Coordenação Geral: Maria de Lourdes Germano

Curadoria: Fritz

Data: 10 a 30 de Abril de 1999

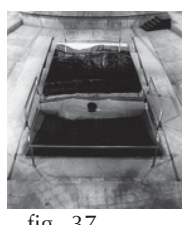

"Gambling", 1999.

aço inox e espelho

$50 \mathrm{~m}^{2}$

Coleção da artista

Participação em Exposições:

"II Semana de Arte Fernando Furlanetto: Fotografia". Teatro Municipal de São João da Boa Vista, S. J. Boa Vista. 1999. 


\section{"Território Expandido"}

SESC Pompéia, São Paulo, SP

Iniciativa: Estadão Cultura e Prêmio Multicultural Estadão

Realização: Sesc São Paulo

Coordenação Geral: Roberto Senni (SESC) e Artecultura

Curadoria: Angélica de Moraes

Data: 19 de maio a 06 de Junho de 1999

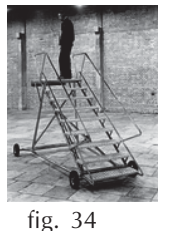

"Exit", 1999.

aço inox, alumínio, rodas de borracha, fone de ouvido e cd player $240 \times 200 \times 360 \mathrm{~cm}$

Trilha sonora: "Jair Rafael at 6 pm", 1999.

Tempo: 16' (looping)

Edição de Audio: Eduardo Tibira

Studio: Turtle Skull

Concepção e Direção: Ana Maria Tavares

Coleção Frac Haute-Normandie (Fonds Régional d'Art Contemporain)

Participação em Exposições:

"Território Expandido", SESC Pompéia, São Paulo. 1999.

\section{"Panorama 99"}

MAm, Museu de Arte Moderna de São Paulo, SP

Direção: Tadeu Chiarelli

Curadoria: Tadeu Chiarelli

Data: 21 de outubro a 19 de dezembro de 1999

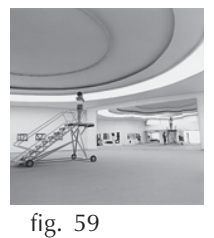

"Exit com Parede Niemeyer", 1999.

aço inox, alumínio, rodas de borracha, fone de ouvido e cd player $240 \times 200 \times 360 \mathrm{~cm}$

Trilha sonora: "Jair Rafael at 6 pm", 1999

Tempo: 16' (looping)

Edição de Audio: Eduardo Tibira

Studio: Turtle Skull

Concepção e Direção: Ana Maria Tavares

\section{Participação em Exposições:}

"Território Expandido", SESC Pompéia, São Paulo. 1999.

“Panorama 99" MAм Museu de Arte Moderna de São Paulo, 1999.

"Panorama 99" MaC Museu de Arte Contemporânea de Niterói, Rio de Janeiro. 1999/2000. 